\title{
Melatonin-Induced Oncostasis, Mechanisms and Clinical Relevance
}

Daniel Cardinali ${ }^{*}$, Germaine Escames ${ }^{2,3}$, Darío Acuña-Castroviejo ${ }^{2,3}$, Francisco Ortiz², Beatriz Fernández-Gil², Ana Guerra Librero², Sergio García-López ${ }^{2}$, Ying Shen ${ }^{2}$ and Javier Florido ${ }^{2}$

${ }^{1}$ BIOMED-UCA-CONICET and Department of Teaching and Research, Faculty of Medical Sciences, Pontificia Universidad Católica Argentina, C1107AFD Buenos Aires, Argentina

${ }^{2}$ Centro de Investigación Biomédica, Avda. del Conocimiento s/n, 18016, Parque Tecnológico de Ciencias de la Salud, Universidad de Granada, Granada, Spain

${ }^{3}$ Departamento de Fisiología, Facultad de Medicina, Universidad de Granada, Granada, Spain

\begin{abstract}
Melatonin is a natural substance ubiquitously distributed and present in almost all living species, from unicellular organisms to humans. Melatonin is synthesized not only in the pineal gland but also in most tissues in the body where it may have a cytoprotective function via paracrine or autocrine effects. Melatonin is effective in suppressing neoplastic growth in a variety of tumors. The mechanisms involved include antiproliferative effects via modulation of cell cycle, ability to induce apoptosis in cancer cells, anti-angiogenic and antimetastatic effects, anti-estrogenic activity, the capacity to decrease telomerase activity, immune modulation, and direct and indirect antioxidant effects. Besides these oncostatic properties, melatonin deserves to be considered in the treatment of cancer for two other reasons. First, because its hypnotic-chronobiotic properties, melatonin use that can allow the clinician to effectively address sleep disturbances, a major co-morbidity in cancer. Second, because melatonin's anxiolytic and antidepressant effects, it has a possible application in two other major co-morbidities seen in cancer patients, i.e. depression and anxiety. This report summarizes the possible mechanisms involved in melatonin oncostasis and reviews what is known about the clinical application of melatonin as an adjuvant therapy in cancer patients.
\end{abstract}

Keywords: Melatonin; Cancer; Apoptosis; Antioxidant; Angiogenesis; Estrogen signaling pathway; Metastasis

Abbreviations: 13-HODE: 13-hydroxyoctadecadienoic Acid; AKT: Protein Kinase B; AIF: Apoptosis-Inducing Factor; Bax: B cell lymphoma Bcl-2 associated X protein; Bid: BH3 InteractingDomain Death Agonist; Ca2+/CaM: Calcium/Calmodulin; cAMP: Cyclic Adenosine Monophosphate; Cdk: Cyclin/Cyclin-Dependent Kinase; COX: Cyclooxygenase; E2: Estradiol; EGF: Epidermal Growth Factor; EGFR: Epidermal Growth Factor Receptor; EMT: EpithelialMesenchymal Transition; ER: Estrogen Receptor; ERE: Estrogen Response Element; ERK: Extracellular-Signal-Regulated Kinase; ET-1: Endothelin-1; GSK3ß: Glycogen Synthase Kinase 3; Hif1a: HypoxiaInducible Factor 1; IGF: Insulin-Like Growth Factor; IL: Interleukin; iNOS: Inducible Nitric Oxide Synthase; L1: Element 1 Retrotransposon; MAPK: Mitogen-Activated Protein Kinase; MET: Mesenchymal-ToEpithelial Transition; MT: Melatonin Receptor; mTOR: Mammalian Target Of Rapamycin; MyD88: Myeloid Differentiation Primary Response Gene 88; NF- $\kappa$ B: Nuclear Factor Kappa-Light-ChainEnhancer Of Activated B Cells; NK: Natural Killer; NO: Nitric Oxide; PI3K: Phosphatidylinositol-4,5-Bisphosphate 3-Kinase; PK: Protein Kinase; RNS: Reactive Nitrogen Species; ROS: Reactive Oxygen Species; SCN: Suprachiasmatic Nuclei; Smad: Mothers Against Decapentaplegic Homolog; Sirt: Sirtuin; TERT: Telomerase Catalytic Protein Component; TGF: Transforming Growth Factor; Th: T Helper; TNF: Tumor Necrosis Factor; uPA: Urokinase-Type Plasminogen Activator; VEGF: Vascular Endothelial Growth Factor

\section{Introduction}

Melatonin is a ubiquitous methoxyindole present in most living species, including unicellular microorganisms, plants, most invertebrates and vertebrates and humans. The first function of melatonin in phylogeny may have been cytoprotective [1]. As such, melatonin could be among the natural molecules that are effective in treating neoplastic malignancies. Despite a number of studies that have established the potentiality of melatonin as an adjuvant in the treatment of cancer melatonin's importance on cancer therapy remains largely unappreciated. Several aspects of this subject have been reviewed elsewhere [2-8]. The aim of this report is to update the present knowledge on the possible mechanisms involved in melatonin oncostasis (Figure 1) and to assess what is known about the therapeutic application of melatonin in cancer patients.

\section{Melatonin Oncostasis}

\section{Antiproliferative effects}

Numerous studies have shown that melatonin has remarkable oncostatic properties and can reduce the promotion and/or progression of tumors. Its antiproliferative properties have been demonstrated in an extensive variety of tumors including breast, endometrial, prostate, colon, and ovarian cancers, choriocarcinoma, melanoma, neuroblastoma, osteosarcoma, and leukemia, with particular efficacy in lymphoproliferative tumors [9-15] (Figure 2).

Melatonin exerts direct anticancer actions by inhibiting the proliferation and growth of tumor cells. The potential signaling pathway responsible for inhibiting cell proliferation requires further investigation, but several explanations are possible, as follows.

Modulating the cell cycle: Melatonin increases the duration of the cell cycle in cancer cells by either expanding the G1 phase (thus

*Corresponding author: Daniel Cardinali, Director, Departamento de Docencia e Investigación, Facultad de Ciencias Médicas, Pontificia Universidad Católica Argentina, Av. Alicia Moreau de Justo 1500, 4o piso, 1107 Buenos Aires, Argentina, Tel: +54 11 43490200; E-mail: danielcardinali@uca.edu.ar; danielcardinali@fibertel.com.ar

Received December 29, 2015; Accepted February 02, 2016; Published February 19, 2016

Citation: Cardinali D, Escames G, Acuña-Castroviejo D, Ortiz F, Fernández-Gil B, et al. (2016) Melatonin-Induced Oncostasis, Mechanisms and Clinical Relevance. J Integr Oncol S1: 006. doi:10.4172/2329-6771.S1-006

Copyright: (c) 2016 Cardinali D, et al. This is an open-access article distributed under the terms of the Creative Commons Attribution License, which permits unrestricted use, distribution, and reproduction in any medium, provided the original author and source are credited. 
Citation: Cardinali D, Escames G, Acuña-Castroviejo D, Ortiz F, Fernández-Gil B, et al. (2016) Melatonin-Induced Oncostasis, Mechanisms and Clinical Relevance. J Integr Oncol S1: 006. doi:10.4172/2329-6771.S1-006

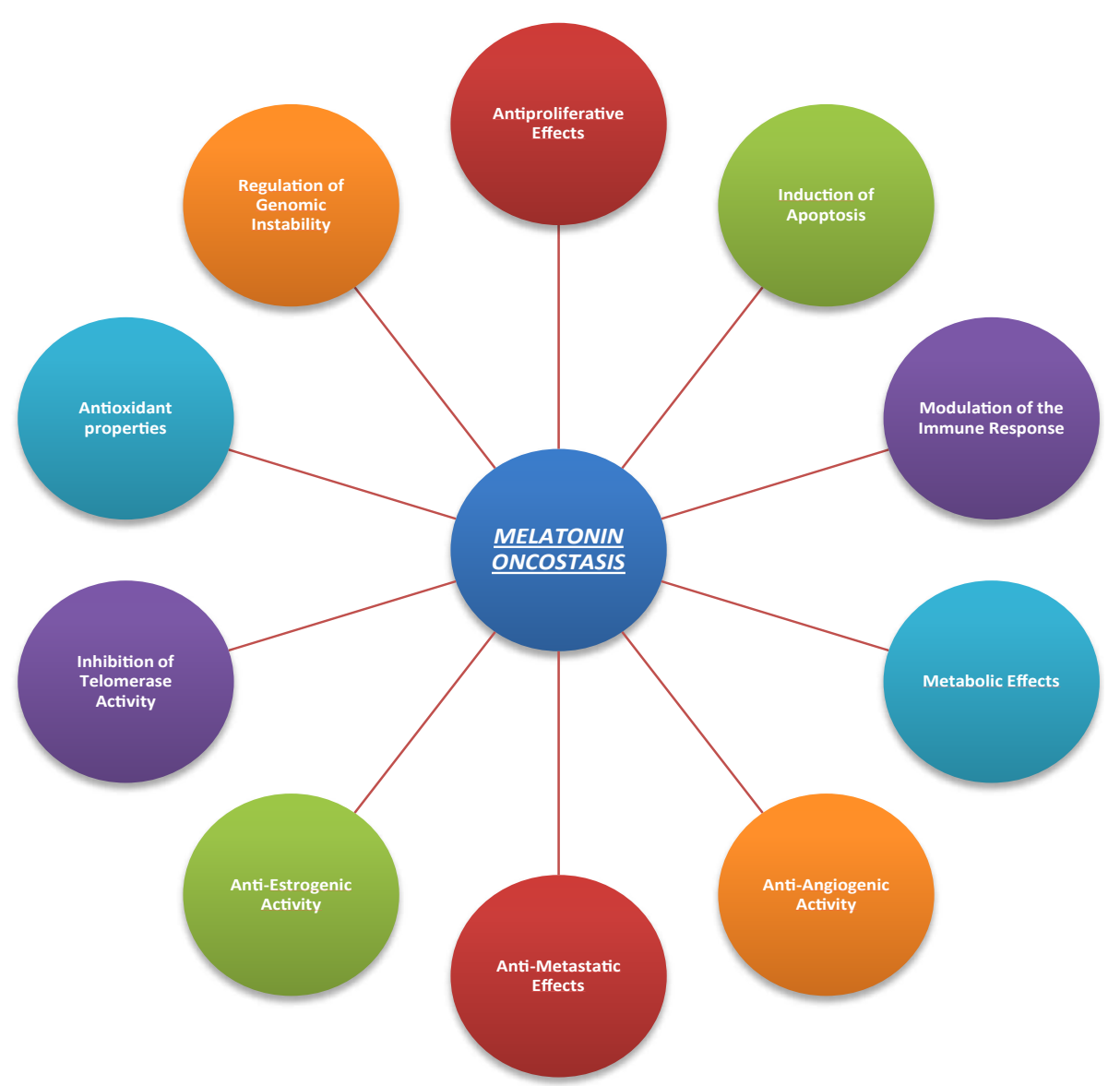

Figure 1: The several mechanisms through which melatonin can exert oncostatic effects. They include antiproliferative effects via modulation of cell cycle, ability to induce apoptosis in cancer cells, metabolic, anti-angiogenic and antimetastatic effects, anti-estrogenic activity, the capacity to decrease telomerase activity, the regulation of genomic instability and of the immune system, and direct and indirect antioxidant effects. See text for details.

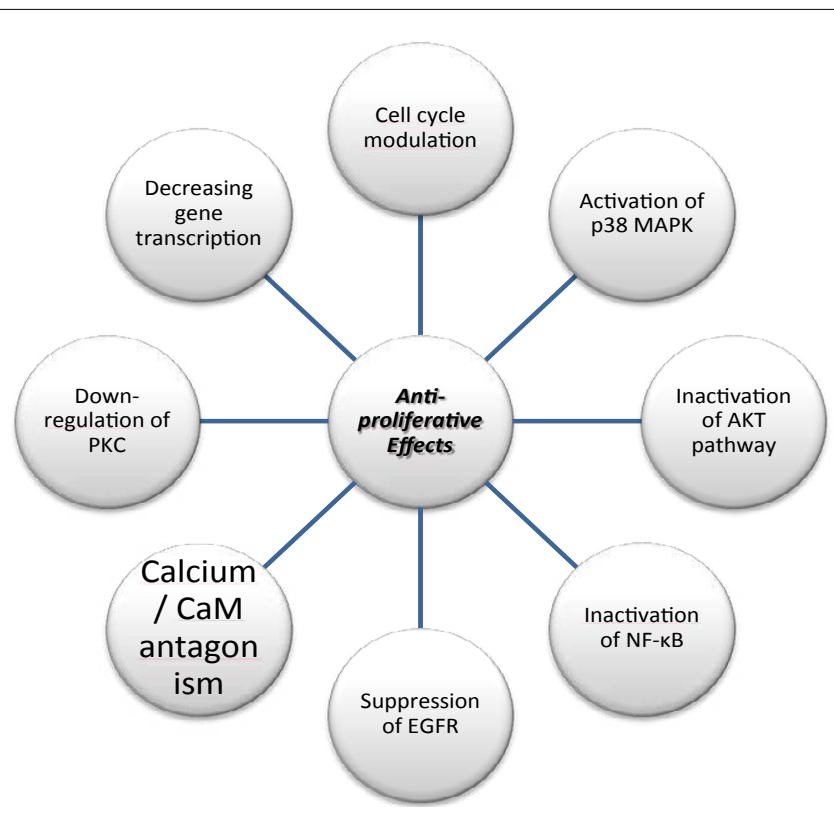

Figure 2: The antiproliferative effects involved in melatonin oncostasis comprise the modulation of cell cycle, activation of p38 MAPK and inactivation of the AKT pathways, inactivation of NF-KB, suppression of EGFR, calcium/CaM antagonism, down-regulation of PKC and the decrease of gene transcription associated with cell proliferation. See text for details. 
delaying the entrance of cells into the $\mathrm{S}$ phase) or by arresting cells in the G2/M phase [15]. Prolonging G1 and delaying progression to $S$ phase is one way that melatonin drives tumor cells to become more differentiated. These data are important because aggressive tumors are associated with poor differentiation [16,17], an effect that seems to be mediated by modulation of expression of genes related to the cell cycle $[18,19]$.

In cancer, the cell cycle is commonly deregulated, contributing to tumorigenesis by amplification or overexpression of cyclins. Melatonin downregulates the activity of cyclin-dependent kinase (CDK) 4 and CDK2 [20]. The cyclin D/CDK4 complex initiates phosphorylation of retinoblastoma protein, which is then further phosphorylated by cyclin E/CDK2. Phosphorylation of phosphorylated retinoblastoma protein triggers the steps required for the cell to enter $S$ phase [21]; thus, inhibition of these CDKs by melatonin may block cancer cell cycle progression. Cyclin $\mathrm{B}$ is associated with CDK1, and melatonin also inhibits the transcriptional activity of cyclin B and CDK1 which after association promotes entry into mitosis, thereby blocking cell progression at the $\mathrm{G} 1$ and $\mathrm{G} 2 / \mathrm{M}$ phases $[13,22]$.

Although melatonin induces alterations in cell cycle progression, these effects depend on the overall metabolic and differentiation state of the cancer cells. Loureiro et al. [23] demonstrated that forcing mitochondrial metabolism in embryonal carcinoma stem cells leads to reduced proliferation and pluripotency and to spontaneous differentiation. Therefore, it can be presumed that the melatonindependent antiproliferative effect requires an active mitochondrial metabolism

Inducing activation of $\mathrm{p} 38$ mitogen activated protein kinase (MAPK): Melatonin induces phosphorylation (activation) of p38 MAPK, suggesting that this signaling kinase plays a key role in cell growth inhibition [24-26]. P38 MAPK activates kinases involved in phosphorylation of cyclin D1, enhancing its proteasome-dependent degradation and delaying progression through G1 [27]. In addition, evidence suggests that p38 MAPK can induce B cell lymphoma Bcl2 associated X protein (Bax) activation, leading to its mitochondrial translocation prior to apoptosis. MAPK signaling pathways are responsible for melatonin antiproliferative effects in some cancer cells $[18,24,26,28]$.

Inactivation of the AKT pathway: Activation of the phosphatidylinositol-4,5-bisphosphate 3-kinase (PI3K)/ protein kinase $\mathrm{B}(\mathrm{AKT}) /$ mammalian target of rapamycin (mTOR) signaling pathway is related to advanced tumor stage [29]. AKT is another important protein kinase $(\mathrm{PK})$ that phosphorylates key signaling molecules controlling cell proliferation, size, differentiation, survival and apoptosis [30]. Evidence suggests that melatonin induces downregulation of the phosphorylation of mTOR and AKT, thus attenuating the expression of survival genes such as McL-1, Bcl-xL, cyclin D1, and cyclin E, both in breast cancer [30,31] and hepatoma cells [32].

\section{Inactivation of nuclear factor kappa-light-chain-enhancer of activated $B$ cells (NF-kB)}

Toll-like receptors are cell surface sensors that can initiate pathways to stimulate cell proliferation, as well as recruiting immune cells to provide support for cancer progression. Toll-like receptors activation, via a myeloid differentiation primary response gene 88 (MyD88)dependent pathway, induces an inflammatory response and promotes activation of the transcription factor NF- $\mathrm{kB}$. The antiproliferative effect of melatonin involves negative regulation of MyD88 [33] and NF- $\kappa \mathrm{B}$ [34]. These factors have proliferative effects by direct action on cyclin D1. NF- $\kappa \mathrm{B}$ also induces interleukins, cytokines, chemokines and cyclooxygenase (COX)-2. COX-2 overexpression and prostaglandin $\mathrm{E}_{2}$ production correlate significantly with invasiveness, prognosis, and survival in several types of cancer [35]. Therefore, COX-2 inhibitors can be important anticancer agents and, additionally, act additively with chemotherapy. Again, the action of melatonin in repressing the expression of COX-2 may account for its oncostatic effects [36].

Suppression of the epidermal growth factor receptor (EGFR) mechanism: Mitogenic regulators such as peptide growth factors, including epidermal growth factor (EGF) and related peptides such as transforming growth factor (TGF)- $\alpha$, which share the same EGFR, are well recognized for playing pivotal roles in cancer progression via autocrine/paracrine stimulation of malignant epithelial cell growth [37]. Thus, an important antiproliferative action of melatonin may depend on the suppression of the EGFR mechanism [38].

Acting as a calcium/calmodulin $\left(\mathrm{Ca}^{+} / \mathrm{CaM}\right)$ antagonist: $\mathrm{Ca}^{2+} / \mathrm{CaM}$ is another important molecule that plays a role in cell proliferation. It is involved in cell cycle progression and cytoskeletal integrity [39]. The antiproliferative effects of melatonin in certain cancer cells may depend on melatonin binding to $\mathrm{Ca}^{2+} / \mathrm{CaM}$ as well as on melatonin-induced changes in the intracellular distribution of CaM [39]. CaM binds to many enzymes and activates them, e.g., adenylate cyclase. Repressed adenylate cyclase activity is associated with reduced cAMP levels within cells, which can lead to altered PKA, cAMP binding protein, and p300 coregulator expression/activation, as well as the attenuation of phospho-activation and transactivation of various transcription factors [40]. Therefore, melatonin, acting as a CaM antagonist, may block reentry of cells into the cell cycle and mitosis [38].

Down-regulation of PKC: PKC appears to promote tumor growth because cytoskeletal proteins phosphorylated by PKC are necessary for mitosis. Melatonin down-regulation of PKC can be thus another mechanism involved in its oncostatic effect [38].

Decreasing gene transcription associated with cell proliferation: The transcription of Nestin, Bmi-1, and Sox 2 has been used as a marker of cell proliferation. These genes are involved in the development of the nervous system [41] and in cancer progression [42-44]. Melatonin at high concentrations decreases cell viability and decreases transcript levels of genes associated with cell proliferation [45]. In addition, melatonin significantly increases gene expression of endocan and downregulates the activity of alkaline phosphatase and lactate dehydrogenase, thereby promoting differentiation of cancer cells, which may concur to melatonin's anticancer properties [46].

\section{Ability to induce apoptosis}

Although melatonin protects normal cells from apoptosis $[47,48]$ it promotes apoptotic cell death in several types of cancer cells [10,49-53]. The reason for this discrepancy is not known. Therefore, a mechanistic clarification is needed regarding the differential responses of normal and cancer cells to melatonin in terms of apoptosis regulation.

The effects of melatonin on apoptosis are mediated by different and interacting pathways as

Activation of p53-related pathways: Melatonin-based apoptosis is assumed to involve activation of $\mathrm{p} 53$-related pathways. The $\mathrm{p} 53$ protein acts in apoptosis, cell cycle arrest, and DNA repair [54]; it causes cell cycle arrest primarily by activating the transcription of a cyclindependent kinase inhibitor, p21/waf1, and induces apoptosis via the 
transcriptional activation of the pro-apoptotic Bcl-2 family member Bax gene [55].

Melatonin enhances p53 protein expression and that of several pro-apoptotic proteins including Bax and p21 [56] and depresses phosphorylated mouse double minute 2 homolog (MDM2), a major physiological antagonist of $\mathrm{p} 53$. AKT activation is performed through PI3K-dependent phosphorylation, and phosphorylated AKT (AKT-P) is required to phosphorylate MDM2, thus allowing MDM2 to enter into the nucleus and interact with p53. Melatonin significantly reduces the AKT-P/total AKT ratio [28].

Inactivation of the p53 gene is commonly observed in human cancer and is associated with resistance to cell death [57]. More than $50 \%$ of human cancers exhibit loss of normal p53 function and/or defects in the p53 signaling pathway. Therefore, agents that might inhibit the development of resistance to chemotherapy could be useful in clinical practice.

Activation of intrinsic and extrinsic apoptotic pathways: Several studies using different tumor cell types have also reported that melatonin induces caspase 3 and 9 activation [24,58,59]. Other studies have shown the release of pro-apoptotic agents from mitochondria, triggered by melatonin in tumor cells $[10,24]$. The mechanisms of melatonin's induction of apoptosis include mitochondrial membrane depolarization and permeability transition pore induction, which strongly suggests involvement of the mitochondrial-mediated pathway of apoptosis. Melatonin treatment in cholangiocarcinoma increases intracellular reactive oxygen species (ROS), which increase caspase activation because of their toxicity. Therefore, activation of ROS production by melatonin is associated with cytotoxicity in cancer cells [60].

Furthermore, melatonin increases calcium uptake, and the rise in calcium levels may lead to activation of PKCa together with PKC $\delta$ and, in consequence, could trigger the extrinsic apoptotic cascade [6]. In the extrinsic apoptotic pathway, melatonin could induce a pronounced rise in caspase 8 associated with augmented expression of both Fas and its ligand FasL.

The intrinsic and extrinsic pathways are connected by the caspase-8-mediated cleavage of the pro-apoptotic Bcl-2 family member $\mathrm{BH} 3$ interacting-domain death agonist (Bid), which translocates to mitochondria to trigger the release of cytochrome C. Melatonin increases the activation and association of Bax and Bid and is associated with a detectable rise in the expression of both proteins $[11,49]$. For example, melatonin upregulates Bax and the conversion of caspase- 3 to cleaved form in human colorectal cancer cells [15]. Melatonin also promotes $\mathrm{Bcl}-2$ down-regulation [10], suggesting that it may be an important endogenous cell death modulator. Moreover, melatonin synergistically promotes chemotherapy-induced apoptosis, mainly through downregulation of $\mathrm{Bcl} 2$ and elevation of pro-apoptotic proteins.

On the other hand, melatonin induces Bim expression [61]. Bim interacts with other $\mathrm{Bcl}-2$ proteins to antagonize their anti-apoptotic activities, leading to apoptosis. Moreover, Bim is modulated by several transcription factors such as forkhead box proteins $\mathrm{O}$ (FOXO). Melatonin upregulates FOXO3a-mediated activation of the proapoptotic protein Bim and enhances endoplasmic reticulum stressinduced apoptosis through inhibition of COX-2 expression and reduction of Bcl-2 levels, and by an elevation of the pro-apoptotic transcription factor C/EBP homologous protein (CHOP). Woo et al. demonstrated that melatonin has an antitumor function through down-regulation of COX-2 expression by inhibition of NF- $\kappa$ B and p38 MAPK activation [62]. Therefore, the stimulatory effects of melatonin on apoptosis in cancer cells involve both the intrinsic and the extrinsic apoptotic pathways [6].

Regulation of histone deacetylases (HDACs): HDACs are critical regulators of gene expression that enzymatically remove the acetyl group from histones. Recent work has shown evidence of a close relationship between transcriptional repression by blockade of acetylation of histones and apoptosis induction. HDAC4, one of the class IIa HDACs, is an important regulator of gene expression as a part of transcriptional corepressor complexes. HDAC4 nuclear import is necessary for melatonin-induced $\mathrm{H} 3$ deacetylation on the bcl-2 promoter and subsequent bcl-2 suppression [63].

HDAC1s are frequently overexpressed in various types of human cancer, melatonin treatment decreasing expression of HDAC1 [64]. Fan et al. reported that melatonin acts as a suppressor in colorectal cancer cells and osteosarcoma cells via HDAC signaling inhibition. On the other hand, HDAC1 inhibitors induce ROS production, so oxidative stress might be an important mechanism by which melatonin induces cancer cell death [64].

Melatonin also downregulates sirtuin (Sirt) 1, thus leading to increased p53 acetylation. Acetylated p53 is preserved from degradation and triggers the intrinsic apoptotic pathway. Moreover, proliferation and viability of cancer cells are impaired through Sirt1 melatonin-dependent inhibition $[39,65]$.

Activation of the TGF $\beta-1$ pathway: Melatonin-dependent late apoptosis is associated with activation of the TGF $\beta-1$ pathway, leading to increased phosphorylated mothers against decapentaplegic homolog (Smad) 2 and Smad3 levels and enabling interaction with Smad4 $[16,28,66]$. Smad2/Smad4 or $S \operatorname{mad} 3 / \mathrm{Smad} 4$ complexes can thus enter the nucleus where they lead to the transcriptional induction of TGF $\beta$ 1-related genes.

These data suggest that different apoptotic pathways are triggered by melatonin because TGF $\beta 1$ is involved only in a late stage of apoptosis. It seems that an early programmed cell death is associated with a significant increase in the p53/MDM2 ratio and with apoptosisinducing factor (AIF) release, and that a late apoptotic process is TGF $\beta 1$-dependent, in which activated caspase 7 is associated with both caspase 9 activation and a reduced $\mathrm{Bcl} 2 / \mathrm{Bax}$ ratio [66].

Thus, although melatonin can reduce cell proliferation by mechanisms that involve cell death by apoptosis [17,67], the exact pathways by which melatonin influences apoptosis and why it has both pro- and anti-apoptotic actions remain to be defined [68,69]. Because melatonin increases the population of necrotic cells, it may play an important role as a tumor suppressor and/or chemotherapeutic agent against tumors.

\section{Modulation of the immune response}

Natural killer (NK) cells are potent effectors of cancer immunoediting and can destroy tumors directly via exocytosis of cytotoxic granules. Other apoptotic-inducing mechanisms of NK cells, such as antibody-dependent cellular cytotoxicity, Fas ligand and tumor necrosis factor (TNF)- $\alpha$ secretion, have been discovered [70,71]. In addition to direct cytotoxicity, NK cells play an important role in the regulation of the anti-tumor adaptive immune response because they produce cytokines such as interferon- $\gamma$, TNF- $\alpha$, interleukin (IL)-10, and several chemokines and growth factors. Hence, NK cells influence 
macrophages, neutrophils and dendritic cells during the immune response [72].

A reduction in circulating NK cells has been described in cancer patients [73]. Numerous reports have demonstrated that melatonin increases the number of NK cells under a variety of conditions. Melatonin administration to leukemic mice results in a quantitative and functional enhancement of NK cells [74]. Although the mechanism has not been defined directly, one possibility is that melatonin acts through increased IL-2 production via melatonin receptors in T-helper cells [75], which leads to an increase in NK cell number and function [76]. T-helper cells play a crucial role in protection against malignancy. In addition, studies performed in patients with cancer have documented that immunological treatment with IL-2 plus melatonin induces a significant increase in the number of NK cells [77]. Therefore, the oncostatic actions of melatonin can also include direct augmentation of NK cell activity [2].

Melatonin increases not only the number of NK cells, monocytes, and leukocytes but also their production of interleukins (IL-2, IL-6, IL-10, IL-12) [9,78]. Melatonin exerts immunomodulatory anticancer activity by (a) augmenting the antitumor immune response by promoting IL-2 release from Th-1 lymphocytes, which may express melatonin receptors; (b) enhancing IL-12 production by dendritic cells in response to IL-2; and (c) decreasing oncogene expression and therefore biological malignancy [79]. Indeed, IL-2 is fundamental as a growth factor for $\mathrm{T}$ lymphocytes, with these cells playing an essential role in the generation of an effective anticancer immunity. Also, melatonin decreases expression of $\mathrm{CD} 4+\mathrm{CD} 25+$ regulatory $\mathrm{T}$ cells and Foxp3 in tumor tissue [80].

Because of its antioxidative effects, melatonin reduces chemotherapy-induced lymphocyte damage [81]. An important strategy in cancer therapy is the activation of the immune system to induce a potent anti-tumor response. Thus the role of melatonin as an immunoenhancer deserves consideration [82] (Figure 3).

\section{Metabolic effects}

Two metabolic effects of melatonin are relevant for its oncostatic activity (Figure 3C).

Inhibition of aerobic glycolysis: Cancer cells use elevated amounts of glucose to enhance lactate production via glycolysis, which is maintained in conditions of high oxygen tension. This type of glucose metabolism is termed aerobic glycolysis [83], a phenomenon inhibited by melatonin, thus reducing glucose metabolism. Melatonin decreases the uptake of glucose and modifies the expression of the GLUT1 transporter in prostate cancer cells, supporting a critical role in the uptake of glucose by cancer cells [84].

Inhibition of linoleic acid uptake: In addition to glucose metabolism, linoleic acid serves as an energy source for tumor growth and as a specific tumor growth-signaling molecule. Several investigations have shown that high intake of linoleic acid increases growth rates of human and murine tumors $[40,85]$. Linoleic acid is converted within the tumor to 13-hydroxyoctadecadienoic acid (13HODE), which augments the mitogenic effects of EGF and insulin-like growth factor-1 (IGF-1) to enhance downstream phosphorylation of ERK1/2 and AKT, leading to amplified cell proliferation and survival responses [86]. In addition, 13-HODE induces p38 MAPK [86].

Blask et al. $[87,88]$ demonstrated that melatonin directly inhibits tumor growth by suppressing the cAMP-dependent tumor uptake of linoleic acid and its metabolism to the mitogenic molecule 13-
HODE. Melatonin may exert its suppressive effects on tumor linoleic acid metabolism via a $\mathrm{MT}_{1}$ melatonin receptor-mediated reduction in cAMP formation. Blask et al. [89] demonstrated that in human breast cancer xenografts, suppression of the circadian amplitude of nocturnal melatonin production causes a significant increase in linoleic acid uptake and its conversion to 13-HODE, stimulating tumor growth. Light at night suppresses the direct antiproliferative effects of endogenous melatonin on human cancer $[90,91]$. Therefore, some antitumor effects of melatonin correlate with melatonin receptor $\left(\mathrm{MT}_{1} /\right.$ $\mathrm{MT}_{2}$ )-dependent inhibition of linoleic acid uptake [89]. In addition, melatonin could suppress the Warburg effect by reducing 13-HODE formation and thus activation of AKT, which is a major stimulatory pathway for aerobic glycolysis [92].

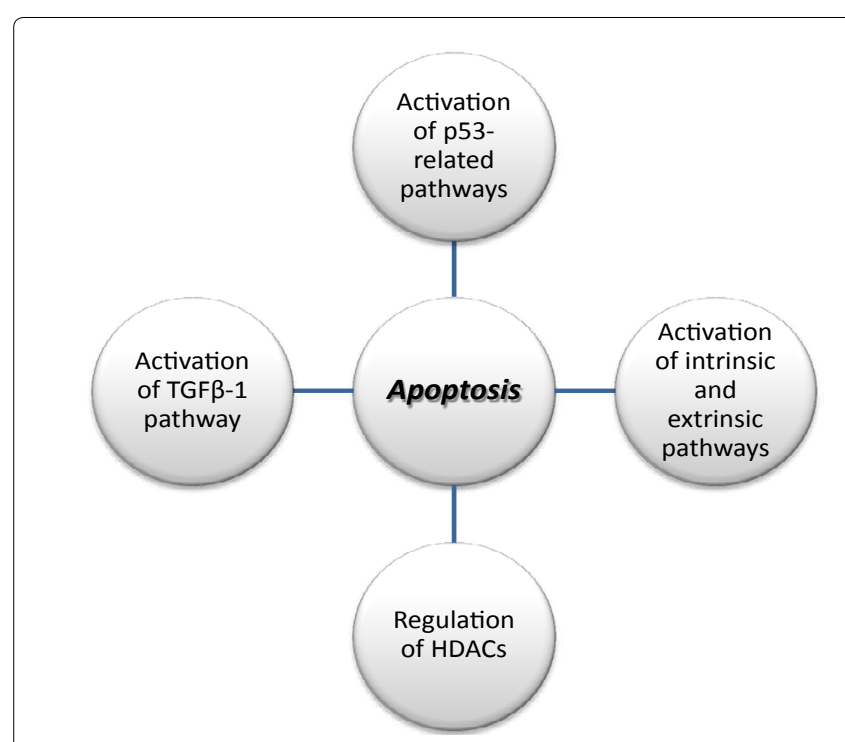

Figure 3A: The promotion of apoptosis in cancer cells produced by melatonin is given by the activation of p53-related pathways, activation of intrinsic and extrinsic apoptotic pathways, regulation of HDACs and activation of TGF $\beta-1$ pathway

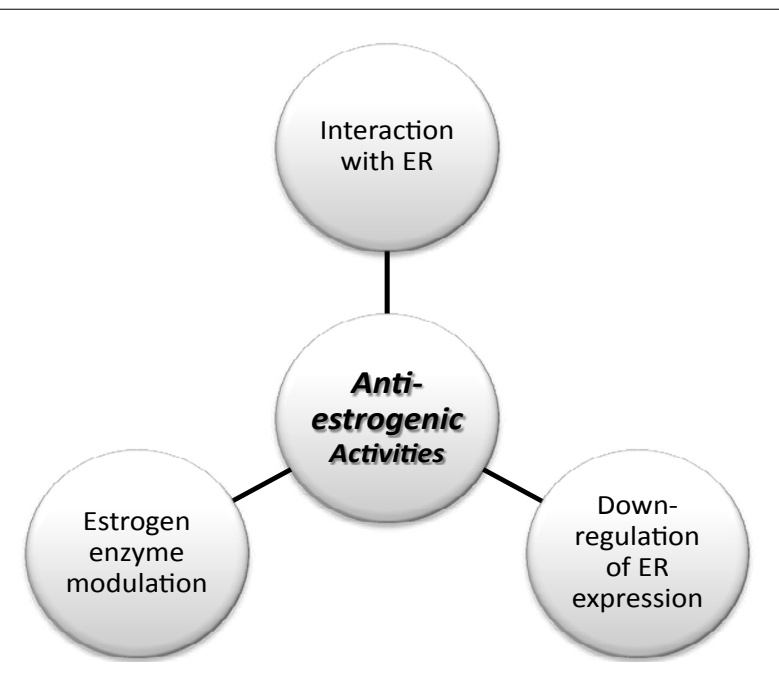

Figure 3B: Melatonin antiestrogenic activity includes the interaction with $E R$, down-regulation of ER expression and inhibition of testosterone aromatization. C. Melatonin metabolic effects related to oncostasis includes inhibition of aerobic glycolysis and of linoleic acid uptake. D. Melatonin effects on genomic instability comprise regulation of circadian gene disruption and normalization of L1 retrotransposon expression. See text for details. 


\section{Anti-angiogenic activity}

Angiogenesis is an essential step in the development of primary tumors. Cancer cell growth relies on new vessel formation for nutrients and oxygen supply [93]. Tumor-induced angiogenesis is a complex process mediated and controlled by growth factors, cellular receptors and adhesion molecules. Hypoxia-inducible factor 1 (HIF1a) induces the expression of several genes such as vascular endothelial growth factor (VEGF), thus increasing new vessel formation and allowing metastatic spreading by connection to the preexisting vessels [94]. Moreover, VEGF appears to be frequently overexpressed in cancer cells, which consistently correlates with tumor size and histologic tumor grade [95].

The anti-angiogenic properties of melatonin have been reported in numerous studies. Melatonin decreases serum levels of VEGF in metastatic cancer patients [96]. Several studies have reported that melatonin-related anti-angiogenic activity in cancer cells is mediated, at least in part, by inhibition of HIF1a nuclear translocation, which is required for its transcriptional activation and subsequent VEGF expression [96,97]. Park et al. [98] demonstrated that melatonin suppresses tumor angiogenesis by inhibiting HIF-1 and VEGF via sphingosine kinase 1 in colon cancer cells. On the other hand, miRNAs play critical roles as modulators of angiogenesis [99]; e.g., overexpression of miRNA 3195 and miRNA 374b inhibits mRNA expression of HIF-1alpha, HIF-2alpha, and VEGF in hypoxia in prostate cancer cells, melatonin enhancing the expression of these miRNAs [100]. Therefore, the anti-angiogenic activity of melatonin can be the result of suppressing of HIF-1alpha by miRNA.

Endothelin-1 (ET-1) synthesis in blood vessels is considered to be one of the main stimulants of angiogenesis in primary tumors and contributes to angiogenesis and metastasis [101]. Melatonin suppresses the formation of ET-1 by inhibiting endothelin-converting enzyme 1 [102]. Additionally, this inhibition is associated with a reduction in edn-1 mRNA expression (the first step in ET-1 synthesis), which in turn results from the inactivation of FOXO1 and NF-B transcription factors [103].

Melatonin also inhibits other tumor growth factors, such as IGF and EGF, which are strong mitogens that stimulate tumor angiogenesis $[102,104]$. Therefore, melatonin seems to suppress cancer angiogenesis through several complementary mechanisms.

\section{Antimetastatic effects}

Metastasis formation involves changes in tumor cells to acquire greater migration and invasion capacity via mechanisms that are not yet fully understood [105]. Melatonin has antimetastatic effects mediated by the inhibition of p38 MAPK and matrix metalloproteinases 2 and 9 [106,107], which are involved in the degradation of the basement membrane and metastatic cell extravasation. Since PKC induces stress fiber thickening and decreases focal adhesion to promote tumor cell migration and invasion, melatonin may reduce stress fiber formation and thickening via PKC inhibition [108].

Epithelial-mesenchymal transition (EMT) has also been seen in cancer cells as they acquire invasive and metastatic phenotypes [109]. EMT is characterized by cellular changes, including the loss of cell adhesion proteins, cytoskeleton reorganization, and increased motility and invasiveness. Also linked to the progression of EMT is the $\mathrm{Wnt} / \beta$ catenin pathway, since $\beta$-catenin is a core component of the adherent junctions due to binding to E-cadherin [110]. Inhibition of glycogen synthase kinase (GSK) $3 \beta$ by AKT or Wnt signaling leads to metastasis.
However, when this pathway is activated, GSK3 $\beta$ phosphorylates $\beta$-catenin, triggering its ubiquitination and subsequent proteasomemediated degradation. Therefore, GSK3 $\beta$ regulates EMT and metastasis via its phosphorylation by AKT [111]. Melatonin, by inhibition of AKT, leads to inhibition of EMT and the development of a metastatic phenotype [112]. Melatonin's activation of GSK3 $\beta$ and inhibition of $\beta$-catenin may thus promote mesenchymal-to-epithelial transition (MET) to suppress the metastatic potential of tumors [113]. Melatonin could suppress metastasis by the blockade of AKT-mediated phosphoinhibition of GSK3 $\beta$, leading to the ubiquitination of $\beta$-catenin, as well as by the suppression of p-p38 MAPK [40].

An increase in inducible nitric oxide synthase (iNOS) expression is associated with early recurrence [114] and metastatic processes $[115,116]$. Belgorosky et al. [117] showed that human colorectal adenocarcinoma cells that express iNOS are more invasive than the non-iNOS-expressing cells. In addition, NO inhibition reduces vascularization, and the inhibition of angiogenesis is accompanied by tumor growth reduction [117]. It is well known that melatonin inhibits both the expression and activity of iNOS and NO levels [118-121].

\section{Anti-estrogenic activities}

The extensively studied anti-estrogenic properties of melatonin are the basis for its oncostatic actions in hormone-dependent mammary cancer [16,41] (Figure 3B).

Interaction with estrogen receptors and down-regulation of their expression, binding to DNA, and transactivation: Melatonin interferes with the activation of the estrogen receptor (ER), behaving as a selective ER modulator [122-124]. ER is a member of a superfamily of ligand-inducible transcription factors that bind to specific recognition sequences in the DNA of responsive genes. These genes become transcriptionally activated to produce mRNAs and proteins involved in numerous cell processes such as proliferation and differentiation. In the absence of estradiol (E2), the inactive receptor is complexed with a variety of proteins that block its ability to interact with DNA whereas in the presence of $\mathrm{E} 2$, the receptor undergoes a conformational change that allows its binding to coactivators, initiating the transcription of target genes. Melatonin downregulates ER expression by suppressing ER gene transcription, resulting in a reduction in ER mRNA and

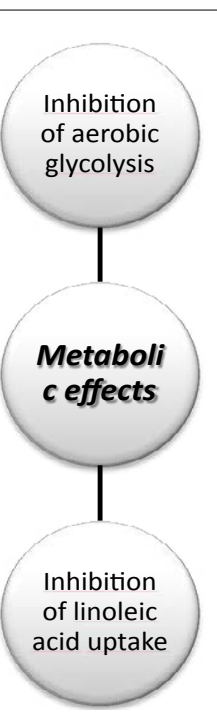

Figure 3C: Melatonin metabolic effects related to oncostasis includes inhibition of aerobic glycolysis and of linoleic acid uptake. 
protein levels [125,126]. Melatonin also inhibits the mitogenic effects of E2 in cancer cells by blocking its ability to stimulate binding of ER to DNA: melatonin inhibits binding of the E2-ER complex to the estrogen response element (ERE) on DNA [38]. Melatonin cannot by itself affect the transcriptional activity of ER in the absence of E2.

The inhibitory effect of melatonin on ER is augmented in the presence of EGF. ER transactivation by melatonin plus EGF renders the receptor less sensitive to E2 and thus less efficient in regulating the transcription of E2-responsive genes that are critical for breast cancer cell proliferation [38]. Furthermore, melatonin not only inhibits the action of growth stimulatory factors but also stimulates the production or release of growth inhibitory factors [127].

The anti-estrogenic effects of melatonin seem to be mediated through $\mathrm{MT}_{1}$ receptors, which are coupled to Gi proteins and inhibit adenylate cyclase activity, thus decreasing the activity of the cAMP/PKA signaling pathway [16]. ER is activated by elevated intracellular cAMP levels. E2 increases cAMP, thus enhancing ER-mediated transcription [16]. The reduction of cAMP could be the mechanism underlying the decreased E2-induced ER transcriptional activity brought about by melatonin [124].

In addition, the association of CaM with the E2-ER complex facilitates its binding to DNA. Therefore, the inactivation of CaM by melatonin could also explain the anti-estrogenic actions of the methoxyindole [128]. Melatonin can be considered a specific inhibitor of E2-induced $\mathrm{ER}_{\alpha}$-mediated transcriptional activation, whereas it does not inhibit ER $\beta$-mediated transactivation [16]. These data suggest that melatonin has an important influence on gene expression in human breast cancer cells.

Estrogen enzyme modulator action: In breast cancer occurring in postmenopausal women, estrogens are synthesized in the mammary tissue from androgenic precursors of adrenal origin. Estrogens are the product of androgen metabolism catalyzed by the aromatase enzyme complex [124]. Aromatase activity in breast cancer tissue is higher than in non-malignant breast tissue, resulting in an increased production of estrogen within breast tumors [129]. Melatonin inhibits the expression and activity of enzymes, such as $\mathrm{P}_{450}$ aromatase, estrogen sulfatase, and $17 \beta$-hydroxysteroid dehydrogenase, involved in the synthesis and transformation of biologically active estrogens, thus behaving as a selective enzyme modulator [130,131]. Melatonin also inhibits the increased proliferation of MCF-7 breast cancer cells induced by testosterone [132]. Because testosterone ultimately leads to proliferation via its transformation into estrogens, the inhibitory effects of melatonin could be due to the blockade of the formation of estrogens from androgens [132]. In addition, melatonin potentiates the effects of other anti-aromatases such as aminoglutethimide [16].

The ability of melatonin to modulate aromatase activity and expression has been explained by the binding of melatonin to MT receptors [133]. Thus, cAMP can be the link between melatonin and aromatase activity in breast cancer cells. In addition, melatonin stimulates the expression and activity of estrogen sulfotransferase, the enzyme responsible for the transformation of E2 into the biologically inactive estrogen sulfates [16].

\section{Capacity to decrease telomerase activity}

Telomerase is a specialized ribonucleoprotein DNA polymerase that extends the telomeres of eukaryotic chromosomes. Activation of telomerase plays an important role in carcinogenesis, providing a mechanism for an unlimited neoplastic cell division capacity [90].
Telomerase is activated in most human cancers, and the death of tumor cells is associated with a decline in detectable telomerase activity [134]. In normal cells, melatonin increases telomerase activity [135] but in cancer cells, it attenuates telomerase activity both in vivo and in vitro [136]. All telomerases contain a telomerase catalytic protein component (TERT) and a RNA subunit, which constitute the minimum structure for telomerase activity. In MCF-7 cancer cells, melatonin inhibits telomerase activity and the expression of the TERT mRNA subunit [136]. Agonism of the nuclear receptor of melatonin decreases TERT RNA levels, whereas agonism of the $\mathrm{MT}_{1}$ membrane receptor increases it [137]. This finding suggests an interaction between the membrane and nuclear melatonin signaling pathways to modulate telomerase activity.

Telomerase is considered an important therapeutic target because telomerase inhibition leads to cancer cell death. The reduction of telomerase expression by melatonin can be an important event in the ability of this molecule to limit tumor growth.

\section{Function as a free radical scavenger}

Melatonin has a marked dose-dependent antioxidative effect, providing protection against damage from carcinogenic substances and acting as a free radical scavenger [138]. ROS generation is a major factor involved in carcinogenesis [139]. Several transcription factors with roles in cell growth and death can be activated by ROS through distinct intracellular pathways. Moreover, free radicals damage all cellular components such as lipids, proteins, and DNA, and damage of DNA by oxidative stress has been implicated as a main contributing factor in the development of cancerous growth [139].

The oxidative damage of mitochondria is also strongly involved in carcinogenesis [140]; e.g., it is hypothesized that mitochondrial changes can be associated with cholangiocarcinoma development [141]. Mitochondrial impairment produces ROS and reactive nitrogen species (RNS) that in turn reduce mitochondrial bioenergetics, favoring cell damage and death [142,143]. Effectively, melatonin treatment significantly inhibits cholangiocarcinoma development [141]. Melatonin is a special class of antioxidant because when scavenging free radicals, it is processed in a series of metabolites that are also free radical scavengers [144]. In addition to direct scavenger activity, melatonin has a genomic effect, inducing expression of antioxidant enzymes such as glutathione peroxidase, glutathione reductase and superoxide dismutase [145] as well as reducing the expression of pro-oxidative enzymes, e.g., iNOS $[118,121]$. Therefore, melatonin may inhibit cancer growth through its ability to directly or indirectly neutralize ROS and RNS production.

Another interesting aspect of melatonin is that it is taken up by mitochondria, providing in situ protection against oxidative damage $[146,147]$. Several reports have shown that melatonin improves mitochondrial function, reduces mitochondrial oxidative status, and increases the activity of the respiratory chain [146,148]. Melatonin, but not other antioxidants (e.g., vitamins $\mathrm{C}$ and $\mathrm{E}, \mathrm{N}$-acetylcysteine) is highly efficient in maintaining mitochondrial glutathione homeostasis in extremely oxidative conditions, closing the mitochondrial permeability transition pore [149] and promoting mitochondrial survival $[150,151]$.

Free radicals and their derivative products can activate nuclear factors such as NF- $\kappa B$, leading to the production of proinflammatory cytokines, which in turn enhance inflammation and further ROS generation [152]. Therefore, antioxidants capable of decreasing intracellular free radicals also can reduce NF- $\kappa B$ activation and 
proliferation of cancer cells [18]. As already mentioned, melatonin has potent anti-inflammatory properties $[118,119,153-156]$ and prevents $\mathrm{NF}-\kappa \mathrm{B}$ activation by oxidative stress [157]. It inhibits growth of glioma cells, and this inhibition is associated with a decrease in basal levels of intracellular free radicals $[19,158]$ and inhibition of NF- $\kappa B$ transcription [18]. Antioxidant agents can enhance the cytotoxic action of chemotherapeutic drugs [159].

\section{Regulation of genomic instability}

Two aspects of genomic stability are relevant for melatonin-induced oncostasis. They include regulation of circadian gene expression and that of the long interspersed element 1 (L1) retrotransposon (Figure 3D).

Circadian disruption: The production of melatonin at night by the pineal gland represents a highly reliable output signal of the circadian clock, and the suppression of pineal melatonin production in response to light at night might explain the rise in cancer that has accompanied industrialization $[160,161]$. The repression of the nocturnal circadian melatonin signal promotes tumor aerobic glycolysis and the expression and activation of the signaling pathways involved in tumor proliferation and survival that drive resistance in cancer cells to endocrine therapies and chemotherapies [40]. Therefore, the melatonin signal regulates metabolic and cell signaling activities to inhibit cancer initiation, promotion, and progression [162], and these effects can be mediated by melatonin $\mathrm{MT}_{1} / \mathrm{MT}_{2}$ receptors [163].

Circadian synchronization is coordinated by the suprachiasmatic nuclei (SCN) of the hypothalamus, as the master clock located in SCN neurons controls peripheral circadian clock genes. At the same time, these genes can subsequently regulate the clock-controlled genes that are involved in the cell cycle [164]. Light may directly affect tumor growth through PER1 and PER2, which in turn regulate cell cycle and apoptosis-regulated genes. Effectively, the deregulation of per and Cry clock genes is related to cancer development. Melatonin is involved in modulating clock genes and therefore could restore abnormal apoptotic processes [6].

Melatonin can also alter DNA methylation patterns, thus decreasing

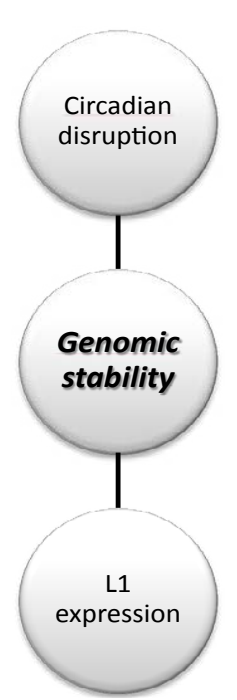

Figure 3D: Melatonin effects on genomic instability comprise regulation of circadian gene disruption and normalization of L1 retrotransposon expression. See text for details. the expression of oncogenic genes while simultaneously up-regulating the expression of tumor suppressor genes. Light exposure at night may affect overall DNA methylation and clock gene expression, including PER2, to promote tumor progression [40].

Regulation of L1 expression: One well-known cause of cancer is genomic instability, and one of the intrinsic DNA-damaging agents that can cause different types of genomic instability in human cancers is the $\mathrm{L} 1$ retrotransposon. It has been reported that melatonin suppresses the expression of $\mathrm{L} 1$ in human cancer in a receptor-mediated manner [165].

On the other hand, it seems that light exposure at night promotes genomic instability. Therefore, upregulation of L1 expression and light exposure at night could be contributing factors driving genomic instability relevant to cancer risk. De Haro et al. reported that expression of endogenous L1 elements in prostate cancer is suppressed by circulating melatonin and that this regulation is disrupted by exposure to light at night, which suppresses nocturnal melatonin production.

The general conclusion is that melatonin exerts anticancer effects by multiple pathways and in a number of experimental models in vivo and in vitro. Table 1 summarizes relevant data on this subject. Melatonin decreases growth in most tumor cell lines by increasing necrosis, decreasing proliferation, and increasing apoptosis $[14,141,166]$. Taken together, the different pathways involved in carcinogenesis, including cell proliferation and metastasis, are important targets of melatonin, which represents a unique molecule able to interact with these different pathways, reducing oncogenesis. Further studies are needed to determine the multiple oncostatic mechanisms of action of melatonin.

In addition, melatonin increases the efficacy of anticancer drugs and has multiple protective effects against drug toxicity $[167,168]$. The data support the clinical use of melatonin in the co-treatment of cancer.

\section{Clinical Application of Melatonin in Cancer}

Three are the major reasons why melatonin deserves to be considered in the treatment of cancer. First, melatonin is a hypnoticchronobiotic agent that can allow the clinician to effectively address sleep disturbances, a major co-morbidity in cancer. Second, the anxiolytic and antidepressant effects of melatonin underline its possible application in two other major co-morbidities (i.e. depression and anxiety) in cancer patients, Third, melatonin has a number of oncostatic properties (as reviewed in the previous sections of this article) that could make it an effective adjuvant of chemotherapy and radiotherapy. We will briefly review these three possible applications of melatonin from a clinical standpoint.

Sleep disorders are very common among cancer patients [169]. However, they generally remained underdiagnosed and poorly treated [170-173]. In a cross-sectional survey study on nearly 1,000 cancer patients to examine the prevalence of sleep problems, sleep disturbance was most prevalent among the lung and breast cancer patients. Sleep complains included excessive fatigue (44\% of patients), restlessness leg syndrome (41\%), insomnia (31\%) and excessive diurnal somnolence (28\%) [174]. It must be noted however that an imprecise conceptualization of sleep has led to narrowly focused interventions being diffusely targeted to symptoms, rather than focused and specific to one or more sleep disorders underlying those symptoms [175]. This is important because although many interventions for sleep in cancer have shown efficacy, the majority of these studies are too targeted to undefined subtypes of insomnia. 
Citation: Cardinali D, Escames G, Acuña-Castroviejo D, Ortiz F, Fernández-Gil B, et al. (2016) Melatonin-Induced Oncostasis, Mechanisms and Clinical Relevance. J Integr Oncol S1: 006. doi:10.4172/2329-6771.S1-006

Page 9 of 25

\begin{tabular}{|c|c|c|c|}
\hline Subjects & Measured & Results & Ref \\
\hline $\begin{array}{l}20 \text { women with clinical stage I or II } \\
\text { breast cancer }\end{array}$ & $\begin{array}{l}\text { Plasma melatonin } \\
\text { levels over } 24 \mathrm{~h}\end{array}$ & $\begin{array}{l}\text { In } 10 \text { patients, whose tumors were estrogen receptor positive, the nocturnal increase in plasma } \\
\text { melatonin was much lower than that observed in } 8 \text { control subjects. Women with the lowest peak } \\
\text { concentration of melatonin had tumors with the highest concentrations of estrogen receptors. } \\
\text { A significant correlation was found between the peak plasma melatonin concentration and the } \\
\text { tumor estrogen receptor concentration in } 19 \text { of the patients }\end{array}$ & [218] \\
\hline $\begin{array}{l}\text { Normal individuals, women with breast } \\
\text { cancer, and women at high risk for } \\
\text { breast cancer }\end{array}$ & $\begin{array}{l}\text { Plasma melatonin } \\
\text { levels over } 24 \mathrm{~h}\end{array}$ & $\begin{array}{l}\text { The mean daytime and nighttime plasma levels, and the range of melatonin day to night differences } \\
\text { for women with breast cancer and women at high risk for breast cancer were comparable to } \\
\text { each other and to the normal subjects. Women with estrogen or progesterone receptor-positive } \\
\text { tumors had a significantly lower mean plasma melatonin day to night difference.A strong inverse } \\
\text { correlation was observed between the plasma melatonin concentration and the quantities of } \\
\text { estrogen or progesterone receptor in the primary tumor. Plasma melatonin did not correlate } \\
\text { with tumor glucocorticoid receptor content or stage of breast cancer among these patients, or } \\
\text { with menopausal status, age, parity, or the plasma levels of estrone, estradiol, progesterone or } \\
\text { gonadotropins among all individuals studied. }\end{array}$ & {$[219]$} \\
\hline $\begin{array}{l}42 \text { cancer patients of both sexes } \\
\text { (breast cancer, 10; lung cancer, 13; } \\
\text { colon cancer, 11; soft tissue sarcoma, } \\
\text { 4; testicular cancer, } 1 \text {; Hodgkin's } \\
\text { disease, 1; peritoneal mesothelioma, 2). }\end{array}$ & $\begin{array}{c}\text { Melatonin serum } \\
\text { levels before and } 28 \\
\text { days after each cycle } \\
\text { of chemotherapy }\end{array}$ & $\begin{array}{l}\text { Regardless of the type of tumor and chemotherapeutic regimen, } 12 / 16 \text { patients }(75 \%) \text { whose } \\
\text { melatonin enhanced after chemotherapy had an objective regression. In contrast, } 2 / 26 \text { patients } \\
\text { only }(8 \%) \text { whose melatonin did not enhance after chemotherapy had a clinical response. } \\
\text { The percentage of objective responses was statistically significantly higher in patients with a } \\
\text { chemotherapy-induced melatonin increase than in those with no melatonin increase }\end{array}$ & [220] \\
\hline $\begin{array}{l}35 \text { patients with breast cancer }(23 \\
\text { primary tumors); } 28 \text { patients with } \\
\text { untreated benign breast disease }\end{array}$ & $\begin{array}{l}\text { Serum melatonin } \\
\text { levels over } 24 \mathrm{~h}\end{array}$ & $\begin{array}{l}\text { A } 50 \% \text { depression of peak and amplitude found in the group of patients with primary breast } \\
\text { cancer. The peak significantly declined with increasing tumor size: } 27 \% \text { at Stage T1, } 53 \% \text { at T2 } \\
\text { and } 73 \% \text { at T3. Patients with secondary breast cancer had a melatonin profile similar to controls }\end{array}$ & {$[221]$} \\
\hline 86 patients with breast cancer & $\begin{array}{l}\text { Daytime plasma } \\
\text { melatonin values }\end{array}$ & $\begin{array}{l}\text { Patients in the advanced disease group had significantly higher levels than those in the adjuvant } \\
\text { treatment group, and patients with progressive disease had significantly higher values than those } \\
\text { in remission or with stable disease. No significant differences were found between different } \\
\text { dominant metastatic disease sites. Multiple-regression tests showed a significant inverse } \\
\text { correlation between survival and melatonin values }\end{array}$ & {$[197]$} \\
\hline $\begin{array}{l}\text { Patients with bening (14) or malignant } \\
\text { (10) breast cancer vs. } 160 \text { controls }\end{array}$ & $\begin{array}{l}\text { Daily pattern of } \\
\text { urinary aMT6s }\end{array}$ & $\begin{array}{l}\text { Women with malignant tumors had significantly lower } 24 \mathrm{~h} \text { concentrations of urinary aMT6s with } \\
\text { a decrease in the amplitude of the rhythm compared to women with benign tumors. The amount } \\
\text { of urinary aMT6s was dependent upon the age of the subject but was not affected by either } \\
\text { menopausal status or body mass index. However, when the women with malignant tumors were } \\
\text { compared with a large group of normal women of the same age their urinary aMT6s levels were } \\
\text { not outside the normal range }\end{array}$ & {$[222]$} \\
\hline $\begin{array}{l}17 \text { patients with breast cancer ( } 9 \\
\text { primary tumors); } 4 \text { patients with } \\
\text { untreated benign breast disease }\end{array}$ & $\begin{array}{l}\text { Serum melatonin and } \\
\text { aMT6s levels over } \\
24 \mathrm{~h}\end{array}$ & $\begin{array}{l}\text { Nocturnal melatonin and aMT6s levels and their circadian amplitudes were significantly depressed } \\
\text { in the group of patients with primary breast cancer. In contrast, patients with secondary breast } \\
\text { cancer showed nocturnal melatonin and aMT6s concentrations and amplitudes similar to benign } \\
\text { breast disease }\end{array}$ & {$[223]$} \\
\hline $\begin{array}{l}8 \text { young men, } 7 \text { elderly patients with } \\
\text { benign prostatic hyperplasia and } 9 \\
\text { patients of similar age with primary } \\
\text { prostate cancer }\end{array}$ & $\begin{array}{l}\text { Serum and urine } \\
\text { melatonin and aMT6s } \\
\text { levels over } 24 \mathrm{~h}\end{array}$ & $\begin{array}{l}\text { The circadian patterns of melatonin and aMT6s in serum were very similar in the different groups. } \\
\text { Mean value and amplitude were significantly depressed by } 40-60 \% \text { in with primary prostate } \\
\text { cancer ( } 40-60 \%) \text { as compared to the other groups. Circadian rhythms similar to those of serum } \\
\text { were found in urine }\end{array}$ & [224] \\
\hline $\begin{array}{l}138 \text { women ( } 68 \text { were diagnosed with } \\
\text { endometrial cancer, } 70 \text { had abnormal } \\
\text { bleedingi }\end{array}$ & $\begin{array}{l}\text { Plasma melatonin } \\
\text { levels }\end{array}$ & $\begin{array}{l}\text { A significant correlation was found between melatonin plasma levels and the presence of } \\
\text { endometrial cancer. The mean plasma melatonin value was } 6.1 \mathrm{pg} / \mathrm{ml} \text { in the cancer-positive } \\
\text { group and } 33.2 \mathrm{pg} / \mathrm{ml} \text { in the cancer-negative control group. }\end{array}$ & {$[225]$} \\
\hline $\begin{array}{l}10 \text { patients with untreated non small } \\
\text { cell lung cancer vs. } 10 \text { healthy subjects }\end{array}$ & $\begin{array}{l}\text { Diurnal plasma } \\
\text { rhythm of melatonin, } \\
\text { cortisol and other } \\
\text { hormones }\end{array}$ & $\begin{array}{l}\text { Melatonin levels and melatonin/cortisol ratio were significantly lower in patients. Disruption of } \\
\text { circadian rhythmicity of melatonin levels were found in cancer patients. }\end{array}$ & [226] \\
\hline $\begin{array}{l}127 \text { patients diagnosed with breast } \\
\text { cancer and } 353 \text { matched control } \\
\text { subjects }\end{array}$ & $\begin{array}{l}\text { Levels of aMT6s in } \\
\text { 24-h urine samples }\end{array}$ & $\begin{array}{l}\text { No statistically significant differences in urinary aMT6s concentrations were observed between } \\
\text { women who developed breast cancer and control premenopausal or postmenopausal women }\end{array}$ & [198] \\
\hline $\begin{array}{l}147 \text { women with invasive breast cancer } \\
\text { and } 291 \text { matched control subjects }\end{array}$ & $\begin{array}{l}\text { Levels of aMT6s in } \\
\text { the first morning urine }\end{array}$ & $\begin{array}{l}\text { In logistic regression models, the relative risk of invasive breast cancer for women in the highest } \\
\text { quartile of urinary aMT6s compared with those in the lowest was } 0.59 \text {. This association was } \\
\text { essentially unchanged after adjustment for breast cancer risk factors or plasma sex hormone } \\
\text { levels but was slightly weakened when the analysis included } 43 \text { case patients with in situ breast } \\
\text { cancer and their } 85 \text { matched control subjects. The exclusion of women who had a history of night- } \\
\text { shift work left our findings largely unchanged. }\end{array}$ & {$[227]$} \\
\hline 3,966 postmenopausal women & $\begin{array}{l}\text { Levels of aMT6s in } \\
\text { 12-h overnight urine } \\
\text { samples }\end{array}$ & $\begin{array}{l}\text { Increased melatonin levels were associated with a statistically significantly lower risk of invasive } \\
\text { breast cancer in postmenopausal women. Among the } 3966 \text { women in the cohort, } 40 \text { of the } 992 \\
\text { women in the highest quartile of aMT6s developed breast cancer during follow-up, compared with } \\
56 \text { of the } 992 \text { women in the lowest quartile }\end{array}$ & {$[228]$} \\
\hline $\begin{array}{l}33,528 \text { women (follow-up } 11 \text { years). } \\
525 \text { incident cases of breast cancer }\end{array}$ & $\begin{array}{l}\text { Self-reported sleep } \\
\text { duration. Levels of } \\
\text { aMT6s in 24-h urine } \\
\text { samples }\end{array}$ & $\begin{array}{l}\text { Among women postmenopausal at baseline, breast cancer risk decreased with increasing sleep } \\
\text { duration. Irrespective of gender, urinary aMT6s levels increased with increasing self-reported } \\
\text { hours of sleep. }\end{array}$ & [229] \\
\hline $\begin{array}{l}180 \text { premenopausal women with } \\
\text { incident breast cancer and } 683 \\
\text { matched controls }\end{array}$ & $\begin{array}{l}\text { Levels of aMT6s in } \\
\text { 12-h overnight urine } \\
\text { samples }\end{array}$ & $\begin{array}{l}\text { In logistic regression models, the relative risk of invasive breast cancer for women in the highest } \\
\text { quartile of total overnight aMT6s output compared with the lowest was } 1.43 \text {. A relative risk (OR= } \\
0.68 \text { ) was found between overnight aMT6s level and breast cancer risk in women with invasive } \\
\text { breast cancer diagnosed }>2 \text { years after urine collection and a significant inverse association in } \\
\text { women with a breast cancer diagnosis }>8 \text { years after urine collection }(\mathrm{OR}, 0.17) \text {. }\end{array}$ & {$[230]$} \\
\hline
\end{tabular}




\begin{tabular}{|c|c|l|}
\hline Subjects & Measured & Results \\
\hline $\begin{array}{c}\text { Morning levels of } \\
\text { on rotating night shifts vs } 319 \text { working } \\
\text { on only day basis }\end{array}$ & $\begin{array}{c}\text { aMT6s in urine } \\
\text { samples. Computer- } \\
\text { assisted measure } \\
\text { of mammo-graphic } \\
\text { density }\end{array}$ & $\begin{array}{l}\text { The adjusted means of percentage of mammographic density and absolute density were slightly, } \\
\text { non significantly, higher among women working rotating night shifts. There was no significant } \\
\text { association between morning aMT6s and mammographic density }\end{array}$ \\
$\begin{array}{c}\text { [231] } \\
\text { of 251 breast cancer cases and 727 } \\
\text { matched controls }\end{array}$ & $\begin{array}{c}\text { Morning levels of } \\
\text { aMT6s in urine } \\
\text { samples. }\end{array}$ & $\begin{array}{l}\text { No significant association was found between aMT6s and breast cancer risk, either overall (for } \\
\text { highest third vs. lowest, multivariable-adjusted odds ratio = 0.90, 95\% confidence interval: 0.61, } \\
\text { 1.33) or by menopausal status. }\end{array}$ \\
\hline [232]
\end{tabular}

aMT6s: 6-sulfatoxymelatonin

Table 1: Melatonin levels in cancer patients.

The possible causes of sleep disorders in patients with cancer are diverse; when pre-existing sleep problems occur they often seem to be aggravated by cancer. Cancer itself (e.g. tumor invasion symptoms, pain), chemotherapy, corticosteroid treatment, environmental factors or psychological distress are among the factors to contribute to disruption of sleep. Sleep loss can be followed by immunosuppression thus impacting on the course of the disease $[169,170,176,177]$.

The type and frequency of hypnotic medication were recorded in a sample of 1984 patients who had previously underwent cancer treatment [178]. Hypnotics were taken by $22.6 \%$ of patients. Among the factors associated with increased use of hypnotic medication, to be older, to have more stressful life events experienced during the past 6 months, to suffer higher levels of anxiety or past or current chemotherapy treatment, were quoted. Almost $80 \%$ of participants who were taking drugs were prescribed benzodiazepines (mostly lorazepam and oxazepam), followed by zopiclone (9\%). It must be noted that regardless that many drugs are currently approved for the treatment of insomnia, very few have been tested for safety or efficacy in patients with cancer [179].

Melatonin can have a place in treating sleep disorders in cancer patients. Its potentiality in treating sleep disturbances is relevant because the sleep-promoting compounds that are usually prescribed in cancer patients, like benzodiazepines and related $\mathrm{Z}$ drugs, have many adverse effects, such as next-day hangover, dependence and impairment of cognition. Indeed, a number of studies point out to a beneficial effect of melatonin in a wide variety of sleep disorders [180] and melatonin is increasingly recognized as an effective medication to stop benzodiazepine/Z drug abuse in patients [181]. Melatonin has been used for improving sleep in patients with insomnia mainly because it does not cause hangover or show any addictive potential. Melatonin's efficacy has been demonstrated in most [182,183] but not all meta-analysis [184]. Brain imaging studies in awake subjects have revealed that melatonin modulates brain activity pattern to one resembling that of actual sleep [185]. A consensus of the British Association for Psychopharmacology on evidence-based treatment of insomnia, parasomnia and circadian rhythm sleep disorders concluded that melatonin is the first choice treatment when a hypnotic is indicated in patients over 55 years [186].

As melatonin exhibits hypnotic and chronobiotic properties of a short duration, the need for the development of prolonged release preparations of melatonin or of melatonin agonists with a longer duration of action on sleep regulatory structures in the brain arose. Slow release forms of melatonin (e.g., Circadin', a 2 mg- preparation developed by Neurim, Tel Aviv, Israel, and approved by the European Medicines Agency, EMEA, in 2007) and the melatonin analogs ramelteon (approved by the Food and Drug Administration, FDA, in 2005), agomelatine (approved by EMEA in 2009) and tasimelteon (approved by FDA in 2013) are examples of this strategy. It must be noted that as shown by the binding affinities, half-life and relative potencies of the different melatonin agonists it is clear that studies using 2-5 mg melatonin/day are unsuitable to give appropriate comparison with the effect of the above mentioned compounds, which in addition to being generally more potent than the native molecule are employed in considerably higher amounts [180].

Concerning the second reason why melatonin can be useful in cancer patients, depression is a frequent and serious comorbid condition affecting the quality of life. Such comorbidity reduces the compliance with treatment and aggravates the physical consequences of the disease. Although there are studies showing that about $40 \%$ of tumor patients need professional psycho-oncological support [187] only less than $10 \%$ of patients are referred for psychosocial intervention in daily clinical practice [188]. Studies of effective pharmacotherapy are relatively scarce in cancer patients with depression and they are biased by a high number of dropouts due to side effects relating to the use of antidepressants compared to placebo [179]. It is therefore difficult to determine with clarity as to what is the best pharmacological treatment for major depression in cancer patients.

Circadian rhythm abnormalities, as shown by the sleep/wake cycle disturbances, constitute one the most prevalent signs of depression [189]. The disturbances in the amplitude and rhythm of melatonin secretion that occur in patients with depression resemble those seen in subjects with chronobiological disorders, thus suggesting a link between melatonin secretion disturbance and depressed mood. Since melatonin is involved in the regulation of both circadian rhythms and sleep, any antidepressant drug with effects on melatonin receptors could be an advantage in treatment. Melatonin treatment has been found effective to treat circadian rhythm disorders [180,190]. As far as its antidepressant activity, melatonin $(10 \mathrm{mg} /$ day $)$ was inactive to affect bipolar affective disorder [191] and improved sleep with no effect on symptoms of depression in major depressive disorder [192,193]. Among the analogs developed to improve the efficacy of melatonin's effects, agomelatine (Valdoxan ${ }^{\circledR}$, Servier, France) has been licensed by the EMEA for the treatment of major depression disorder in adults. Agomelatine has a unique pharmacological profile as it is both a $\mathrm{MT}_{1} / \mathrm{MT}_{2}$ melatonin receptor agonist and an antagonist of $5-\mathrm{HT}_{2}$ receptors. As the first melatonergic antidepressant, agomelatine displays a non-monoaminergic mechanism of action [180]. $\mathrm{MT}_{1}$ and $\mathrm{MT}_{2}$ receptors also appear to be involved in sedating and anxiolytic effects of melatonergic drugs which have been linked to a facilitatory role of melatonin on $\gamma$-aminobutyric acid transmission [194]. This antiexcitatory action of melatonin may underlie the anxiolytic, antihyperalgesic and antinociceptive effects of melatonergic agents, all them of potential application in cancer patients $[4,181]$. In a doubleblind, placebo-controlled study of 54 women undergoing surgery for breast cancer and receiving $6 \mathrm{mg}$ of melatonin or placebo for 3 months, 
the risk of developing depressive symptoms was significantly lower than placebo [195]. Likewise, health-related quality of life assessment in patients with advanced, non-small cell lung cancer and receiving 10-20 mg melatonin daily was better than placebo, particularly in social well-being [196]. A higher extent of DNA damage was observed in the placebo group, and this was associated with a lower survival, implying the protective effect of melatonin in healthy cells [196]. In another study, 95 postmenopausal women with a prior history of stage 0 -III breast cancer and who had completed active cancer treatment, 3 $\mathrm{mg}$ of melatonin or placebo was used for 4 months. Subjects receiving melatonin experienced significantly greater improvements in subjective sleep quality but there were no significant differences in measures of depression or hot flashes, presumably because of the low amounts of melatonin used [171] (Table 2).

With few exceptions [197-199], melatonin levels were found to be decreased in cancer patients (see Supplementary Table 1). One active issue in scientific research is the possibility that working non-day hours is associated with an increased risk of cancer, most notably breast and prostate cancer. The major idea behind this is that the reduced melatonin secretion plays a crucial role in the occurrence of cancer. A number of studies have addressed this question by employing both case-control and cohort designs, thus supporting [200,201] or not supporting [202] such an association. The inconsistencies may depend on the definition of "shift work" [203]. A major support derives from meta-analysis studies, a procedure that combines data from several studies and treats those data as one large study. Although meta-analyses can be informative, they are questionable because of the dissimilarity among studies.

This argument is also relevant for results on the third aspect of clinical application of melatonin in cancer, i.e. the therapeutic effect of melatonin in cancer patients. Literature data on this point are summarized in the Supplementary Table 2. Two meta-analyses have been published to assess melatonin efficacy in treating cancer patients. The first meta-analysis was a systematic review of randomized controlled trials of melatonin in solid tumor cancer patients and its effect on survival at 1 year [204]. It included 10 studies published between 1992 and 2003 and comprised 643 patients. Melatonin reduced the risk of death at 1 year with effects consisting across melatonin dose, and type of solid cancer. No relevant adverse events were reported.

In the second meta-analysis 8 eligible randomized controlled trials of solid tumor cancers $(n=761)$ were selected [205]. The dosage of melatonin used was $20 \mathrm{mg}$ orally, once a day. Melatonin significantly improved the complete and partial remission and 1-year survival rate and decreased radiochemotherapy-related side effects. It must be noted that all trials examined in both meta-analyses included solid tumor cancers and were unblinded and all except one were conducted by the same group of researchers at the same hospital network.

In addition, relevant negative results concerning melatonin efficacy in cancer patients have been published. In a trial designed to compare whole brain radiation therapy alone to radiation therapy and $20 \mathrm{mg} /$ day melatonin for patients with brain metastases from solid tumors, neither

\begin{tabular}{|c|c|c|c|c|c|c|}
\hline Subjects & Design & $\begin{array}{l}\text { Study's } \\
\text { duration }\end{array}$ & Treatment & Measured & Results & Ref. \\
\hline $\begin{array}{l}33 \text { patients with } \\
\text { metastatic renal } \\
\text { cancer }\end{array}$ & $\begin{array}{l}\text { Randomized } \\
\text { open trial }\end{array}$ & 5 days & $\begin{array}{l}\text { IL-2 alone or IL-2 plus melatonin (10 } \\
\mathrm{mg} / \text { day p.o. at } 2000 \mathrm{~h})\end{array}$ & Clinical outcome & $\begin{array}{l}\text { The frequency of episodes of severe } \\
\text { hypotension and depressive symptomatology } \\
\text { were significantly greater during IL-2 alone } \\
\text { than during IL-2 + melatonin. No other toxicity, } \\
\text { including capillary leak syndrome, vomiting } \\
\text { and fever, were significantly influenced by the } \\
\text { concomitant treatment with melatonin }\end{array}$ & [233] \\
\hline $\begin{array}{l}54 \text { patients with } \\
\text { metastatic solid } \\
\text { tumors }\end{array}$ & Open trial & 2 months & $\begin{array}{l}\text { Melatonin was given i.m. at a daily } \\
\text { dose of } 20 \mathrm{mg} \text { at } 1500 \mathrm{~h} \text { for } 2 \text { months }\end{array}$ & Clinical outcome & $\begin{array}{l}\text { The clinical response was as follows: } 1 \text { partial } \\
\text { response (cancer of pancreas), } 2 \text { minor } \\
\text { responses (colon cancer and hepatocarcinoma) } \\
\text { and } 21 \text { with stable disease. The remaining } 30 \\
\text { patients rapidly progressed within the first } 2 \\
\text { months of therapy }\end{array}$ & [234] \\
\hline $\begin{array}{l}42 \text { patients } \\
\text { with advanced } \\
\text { melanoma }\end{array}$ & $\begin{array}{l}\text { Open label } \\
\text { study }\end{array}$ & $\begin{array}{l}\text { Median } \\
\text { follow-up of } \\
33 \text { weeks }\end{array}$ & $\begin{array}{l}\text { Melatonin from } 5 \text { to } 700 \mathrm{mg} / \mathrm{m}^{2} / \text { day in } \\
\text { four divided doses p.o. }\end{array}$ & $\begin{array}{l}\text { Clinical outcome. Serum } \\
\text { FSH, LH and TSH } \\
\text { levels }\end{array}$ & $\begin{array}{l}6 \text { patients had partial responses and } 6 \text { additional } \\
\text { patients had stable disease. The median } \\
\text { response duration was } 33 \text { weeks for the partial } \\
\text { responders. The toxicity encountered was } \\
\text { minimal and consisted primarily of fatigue in } 17 \\
\text { of } 40 \text { patients. Decreased levels of FSH were } \\
\text { found }\end{array}$ & [235] \\
\hline $\begin{array}{l}63 \text { consecutive } \\
\text { metastatic non } \\
\text { small cell lung } \\
\text { cancer patients }\end{array}$ & $\begin{array}{l}\text { Randomized } \\
\text { open trial }\end{array}$ & 1 year & $\begin{array}{l}\text { Patients were randomized to receive } \\
\text { melatonin }(10 \text { mg p.o. at } 1900 h, n= \\
\text { 31) or supportive care alone }(n=32)\end{array}$ & Clinical outcome & $\begin{array}{l}\text { The percentage of both stabilizations of disease } \\
\text { and survival at } 1 \text { year was significantly higher } \\
\text { in patients treated with melatonin. No drug- } \\
\text { related toxicity was seen in patients treated with } \\
\text { melatonin }\end{array}$ & [236] \\
\hline $\begin{array}{l}20 \text { metastatic non } \\
\text { small cell lung } \\
\text { cancer patients }\end{array}$ & Open trial & 4 weeks & $\begin{array}{l}\text { Melatonin was given p.o. at a daily } \\
\text { dose of } 10 \mathrm{mg} \text { at } 2000 \mathrm{~h} \\
\text { starting } 7 \text { days before the onset of IL-2 } \\
\text { administration. IL-2 was given s.c. at a } \\
\text { dose of } 3 \times 10^{6} \text { IU.m } \mathrm{m}^{2} \text { every } 12 \mathrm{~h} \text { for } 5 \\
\text { days/week for } 4 \text { weeks). In responder } \\
\text { patients a second cycle was given } \\
\text { after a rest-period of } 21 \text { days. }\end{array}$ & Clinical outcome & $\begin{array}{l}\text { A partial response was achieved in } 4 / 20(20 \%) \\
\text { patients. Ten other patients had a stable } \\
\text { disease }(50 \%) \text {, whereas } 6 \text { patients progressed. } \\
\text { Toxicity was low in all cases }\end{array}$ & [237] \\
\hline
\end{tabular}


Citation: Cardinali D, Escames G, Acuña-Castroviejo D, Ortiz F, Fernández-Gil B, et al. (2016) Melatonin-Induced Oncostasis, Mechanisms and Clinical Relevance. J Integr Oncol S1: 006. doi:10.4172/2329-6771.S1-006

Page 12 of 25

\begin{tabular}{|c|c|c|c|c|c|c|}
\hline Subjects & Design & $\begin{array}{l}\text { Study's } \\
\text { duration }\end{array}$ & Treatment & Measured & Results & Ref. \\
\hline $\begin{array}{l}30 \text { advanced } \\
\text { cancer patients }\end{array}$ & $\begin{array}{l}\text { Randomized } \\
\text { open trial }\end{array}$ & 4 weeks & $\begin{array}{l}\text { Patients were randomized to receive } \\
\text { IL-2 }\left(3 \times 10^{6} \mathrm{IU} \cdot \mathrm{m}^{2} \text { twice/daily for } 6\right. \\
\text { days/week for } 4 \text { weeks, with or without } \\
\text { melatonin } 10 \text { or } 50 \mathrm{mg} \text { given daily p.o. } \\
\text { at } 2000 \mathrm{~h}\end{array}$ & Immune parameters & $\begin{array}{l}\text { IL-2 together with melatonin, but not IL-2 } \\
\text { alone, induced a significant increase in mean } \\
\text { number of lymphocytes, T lymphocytes, NK } \\
\text { cells, CD25-positive cells and eosinophils. } \\
\text { Soluble IL-2 receptor and neopterin increase } \\
\text { was significantly higher during IL-2 given twice/ } \\
\text { daily than during IL-2 plus melatonin, while no } \\
\text { difference was seen in TNF rise }\end{array}$ & [238] \\
\hline $\begin{array}{l}35 \text { patients with } \\
\text { advanced tumors } \\
\text { of the digestive } \\
\text { tract (colorectal } \\
\text { cancer: } 14 \text {; } \\
\text { gastric cancer: } \\
8 \text {; hepato- } \\
\text { carcinoma: } 6 \text {; } \\
\text { pancreas adeno- } \\
\text { carcinoma: } 7 \text { ) }\end{array}$ & Open trial & 4 weeks & $\begin{array}{l}\text { Melatonin was given p.o. at a daily } \\
\text { dose of } 50 \mathrm{mg} \text { at } 2000 \mathrm{~h} \text { starting } \\
7 \text { days before the onset of IL-2 } \\
\text { administration. IL-2 was given s.c. at a } \\
\text { dose of } 3 \times 10^{6} \mathrm{IU} . \mathrm{m}^{2} \text { every } 12 \mathrm{~h} \text { for } 6 \\
\text { days/week for } 4 \text { weeks) }\end{array}$ & Clinical outcome & $\begin{array}{l}\text { A complete response was achieved in two } \\
\text { patients (gastric cancer: } 1 \text {; hepatocarcinoma: } 1) \text {. } \\
\text { Six other patients obtained a partial response: } \\
\text { (gastric cancer: } 2 \text {; hepatocarcinoma: } 2 \text {; colon } \\
\text { cancer: } 1 \text {; pancreas cancer: } 1 \text { ). Stable disease } \\
\text { was obtained in } 11 / 35(31 \%) \text { patients, whereas } \\
\text { the remaining } 16 \text { patients }(46 \%) \text { progressed. } \\
\text { The response rate was significantly higher in } \\
\text { untreated patients than in those previously } \\
\text { treated with chemotherapy }\end{array}$ & [239] \\
\hline $\begin{array}{l}82 \text { patients, } 72 \\
\text { of whom showed } \\
\text { distant organ } \\
\text { metastases } \\
\text { (non-small cell } \\
\text { lung cancer: } \\
19 \text {; hepato- } \\
\text { carcinoma: } 16 ; \\
\text { colon cancer: } 15 ; \\
\text { gastric cancer: } \\
11 \text {; cancer of } \\
\text { pancreas: } 11 ; \\
\text { breast cancer: } 6 \text {; } \\
\text { other: } 4 \text { ) }\end{array}$ & Open trial & 4 weeks & $\begin{array}{l}\text { Melatonin was given p.o. at a daily } \\
\text { dose of } 40 \mathrm{mg} \text { at } 2000 \mathrm{~h} \\
\text { starting } 7 \text { days before the onset of IL-2 } \\
\text { administration. IL-2 was given s.c. at a } \\
\text { dose of } 3 \times 10^{6} \mathrm{IU} / \mathrm{m}^{2} \text { every } 12 \mathrm{~h} \text { for } 6 \\
\text { days/week for } 4 \text { weeks) }\end{array}$ & $\begin{array}{l}\text { Clinical outcome, } \\
\text { immune parameters }\end{array}$ & $\begin{array}{l}\text { Objective tumor regression were achieved in } \\
17 / 82(21 \%) \text { patients. The median duration } \\
\text { of response was } 8+\text { months. A stabilization } \\
\text { of disease was obtained in } 30 \text { patients, while } \\
\text { the other } 35 \text { patients progressed. The lack of } \\
\text { progression was associated with a significantly } \\
\text { higher increase in lymphocyte and eosinophil } \\
\text { mean number and with a significantly lower } \\
\text { increase in neopterin mean levels. The } \\
\text { treatment was well tolerated in all patients }\end{array}$ & [240] \\
\hline $\begin{array}{l}14 \text { patients with } \\
\text { metastatic gastric } \\
\text { cancer }\end{array}$ & Open trial & Variable & $\begin{array}{l}\text { Melatonin was given p.o. at a daily } \\
\text { dose of } 50 \mathrm{mg} \text { at } 2000 \mathrm{~h} \text { starting } \\
7 \text { days before the onset of IL-2 } \\
\text { administration. IL-2 was given s.c. at } \\
\text { a dose of } 3 \times 10^{6} \mathrm{IU} / \mathrm{m}^{2} \text { every } 12 \mathrm{~h} \text { for } \\
6 \text { days } / \text { week for } 4 \text { weeks). In patients } \\
\text { in whom the disease did not progress, } \\
\text { a second cycle was given after a rest } \\
\text { period of } 21 \text { days }\end{array}$ & Clinical outcome & $\begin{array}{l}\text { A tumor regression was obtained in } 3 / 14(21 \%) \\
\text { patients, complete response in } 1 \text { and partial in } \\
2 \text {, with a median duration of } 13+\text { months. The } \\
\text { disease stabilized in } 6 / 14(43 \%) \text { patients and } \\
\text { progressed in the remaining } 5(36 \%) \text {. Survival } \\
\text { was significantly longer in patients with response } \\
\text { or stable disease than in those with progression. } \\
\text { Toxicity was low in all cases }\end{array}$ & [239] \\
\hline $\begin{array}{l}14 \text { patients with } \\
\text { un-resectable } \\
\text { hepato-cellular } \\
\text { carcinoma }\end{array}$ & Open trial & Variable & $\begin{array}{l}\text { Melatonin was given p.o. at a daily } \\
\text { dose of } 50 \mathrm{mg} \text { at } 2000 \mathrm{~h} \\
\text { starting } 7 \text { days before the onset of IL-2 } \\
\text { administration. IL-2 was given s.c. at } \\
\text { a dose of } 3 \times 10^{6} \mathrm{IU} / \mathrm{m}^{2} \text { every } 12 \mathrm{~h} \text { for } \\
6 \text { days/week for } 4 \text { weeks). In patients } \\
\text { in whom the disease did not progress, } \\
\text { a second cycle was given after a rest } \\
\text { period of } 21 \text { days }\end{array}$ & Clinical outcome & $\begin{array}{l}\text { Objective tumor regressions were obtained in } \\
5 / 14 \text { ( } 36 \% \text { ) patients (one complete response, } \\
\text { four partial responses), with a median duration } \\
\text { of } 7 \text { months. } 6 \text { patients had stable disease, } \\
\text { while the other } 3 \text { progressed. Toxicity was low } \\
\text { in all cases }\end{array}$ & [241] \\
\hline $\begin{array}{l}50 \text { patients with } \\
\text { brain metastases } \\
\text { due to solid } \\
\text { tumors }\end{array}$ & $\begin{array}{l}\text { Randomized } \\
\text { open trial }\end{array}$ & $1-2$ years & $\begin{array}{l}\text { Supportive care alone (steroids plus } \\
\text { anticonvulsant agents) or supportive } \\
\text { care plus melatonin ( } 20 \mathrm{mg} / \text { day p.o. } \\
\text { at } 2000 \mathrm{~h} \text { ) }\end{array}$ & Clinical outcome & $\begin{array}{l}\text { The survival at } 1 \text { year, free-from-brain- } \\
\text { progression period, and mean survival time } \\
\text { were significantly higher in patients treated } \\
\text { with melatonin than in those who received the } \\
\text { supportive care alone }\end{array}$ & [242] \\
\hline $\begin{array}{l}22 \text { patients with } \\
\text { metastatic renal } \\
\text { cell carcinoma }\end{array}$ & Open trial & 12 months & $\begin{array}{l}\text { Human IFN, } 3 \text { mega- units i.m. } 3 \text { times } \\
\text { per week, plus melatonin, } 10 \mathrm{mg} \text { p.o. } \\
\text { every day }\end{array}$ & Clinical outcome & $\begin{array}{l}\text { There were seven remissions (33\%): three } \\
\text { complete, involving lung and soft tissue and four } \\
\text { partial. Nine patients achieved stable disease, } \\
\text { and five progressed. General toxicity was mild. } \\
\text { Fever, chills, arthralgias, and myalgias occurred } \\
\text { rarely. Leukopenia and hepatic enzyme } \\
\text { elevation were modest and always reversible }\end{array}$ & [243] \\
\hline $\begin{array}{l}14 \text { metastatic } \\
\text { solid tumor } \\
\text { patients }\end{array}$ & $\begin{array}{l}\text { Randomized } \\
\text { open trial }\end{array}$ & 12 days & $\begin{array}{l}\text { Recombinant human TNF was given } \\
\text { at a daily dose of } 0.75 \mathrm{mg} \text { i.v. for } 5 \\
\text { consecutive days. Melatonin was given } \\
\text { p.o. at a daily dose of } 40 \mathrm{mg} \text {, starting } 7 \\
\text { days before TNF }\end{array}$ & Clinical outcome & $\begin{array}{l}\text { Lymphocyte mean number observed at the } \\
\text { end of TNF infusion was significantly higher in } \\
\text { patients treated with TNF plus melatonin than } \\
\text { in those receiving TNF alone. Asthenia and } \\
\text { hypotension were significantly less frequent } \\
\text { in patients treated with TNF plus melatonin, } \\
\text { whereas no difference occurred in the frequency } \\
\text { of fever and chills }\end{array}$ & [244] \\
\hline
\end{tabular}


Citation: Cardinali D, Escames G, Acuña-Castroviejo D, Ortiz F, Fernández-Gil B, et al. (2016) Melatonin-Induced Oncostasis, Mechanisms and Clinical Relevance. J Integr Oncol S1: 006. doi:10.4172/2329-6771.S1-006

Page 13 of 25

\begin{tabular}{|c|c|c|c|c|c|c|}
\hline Subjects & Design & $\begin{array}{l}\text { Study's } \\
\text { duration }\end{array}$ & Treatment & Measured & Results & Ref. \\
\hline $\begin{array}{l}60 \text { patients with } \\
\text { locally advanced } \\
\text { or metastatic } \\
\text { non-small cell } \\
\text { lung cancer who } \\
\text { were randomized } \\
\text { to receive } \\
\text { immune-therapy } \\
\text { or chemo-therapy }\end{array}$ & $\begin{array}{l}\text { Randomized } \\
\text { open trial }\end{array}$ & 6 months & $\begin{array}{l}\text { Immunotherapy consisted of IL-2 ( } 3 \\
\text { million IU/day s.c. for } 6 \text { days/week for } \\
4 \text { weeks) and melatonin ( } 40 \mathrm{mg} / \text { day } \\
\text { orally every day, starting } 7 \text { days before } \\
\text { IL-2); in nonprogressing patients, a } \\
\text { second cycle was repeated after a } 21 \text { - } \\
\text { day rest period, then they underwent } \\
\text { a maintenance period consisting of } \\
\text { one week of therapy every month until } \\
\text { progression. Chemotherapy consisted } \\
\text { of cisplatin and etoposide; cycles of } \\
\text { chemotherapy were repeated every } 21 \\
\text { days until progression }\end{array}$ & Clinical outcome & $\begin{array}{l}\text { No complete response was obtained. Mean } \\
\text { progression-free period and the percentage } \\
\text { survival at } 1 \text { year were significantly higher } \\
\text { in patients treated with immunotherapy } \\
\text { than in those treated with chemotherapy. } \\
\text { Toxicity was substantially lower in patients } \\
\text { receiving immunotherapy than in those given } \\
\text { chemotherapy }\end{array}$ & [245] \\
\hline $\begin{array}{l}30 \text { patients with } \\
\text { gastro-intestinal } \\
\text { tract tumors }\end{array}$ & $\begin{array}{l}\text { Randomized } \\
\text { open trial }\end{array}$ & 1 week & $\begin{array}{l}\text { A high-dose IL-2 (18 million IU/day s.c. } \\
\text { for } 3 \text { days) or low-dose IL-2 ( } 6 \text { million } \\
\text { IU/day s.c. for } 5 \text { days) plus melatonin } \\
\text { ( } 40 \text { mg/day orally). Patients underwent } \\
\text { surgery within } 36 \text { hours from IL-2 } \\
\text { interruption }\end{array}$ & $\begin{array}{l}\text { Clinical } \\
\text { outcomelmmune } \\
\text { parameters }\end{array}$ & $\begin{array}{l}\text { IL-2 plus melatonin were able to prevent } \\
\text { surgery-induced lymphocytopenia but rather } \\
\text { an increased mean number of lymphocytes, T } \\
\text { lymphocytes and T helper lymphocytes were } \\
\text { found. Toxicity was less in patients treated with } \\
\text { IL-2 plus melatonin }\end{array}$ & [246] \\
\hline $\begin{array}{l}14 \text { patients with } \\
\text { untreatable } \\
\text { endocrine tumors } \\
\text { (mostly thyroid } \\
\text { cancer, carcinoid } \\
\text { and endocrine } \\
\text { pancreatic } \\
\text { tumors) }\end{array}$ & $\begin{array}{l}\text { Phase II pilot } \\
\text { study }\end{array}$ & 2 months & $\begin{array}{l}\text { Melatonin was given p.o. at a daily } \\
\text { dose of } 50 \mathrm{mg} \text { at } 2000 \mathrm{~h} \\
\text { starting } 7 \text { days before the onset of IL-2 } \\
\text { administration. IL-2 was given s.c. at } \\
\text { a dose of } 3 \times 10^{6} \mathrm{IU} / \mathrm{m}^{2} \text { every } 12 \mathrm{~h} \text { for } \\
6 \text { days } / \text { week for } 4 \text { weeks). In patients } \\
\text { in whom the disease did not progress, } \\
\text { a second cycle was given after a rest } \\
\text { period of } 21 \text { days }\end{array}$ & Clinical outcome & $\begin{array}{l}\text { A partial response was achieved in } 3 / 12(25 \%) \\
\text { patients (carcinoid tumor: } 1 \text {; neuroendocrine } \\
\text { lung tumor: } 1 \text {; pancreatic islet cell tumor: } 1) \text {. } \\
\text { Another patient with gastrinoma had a more } \\
\text { than } 50 \% \text { reduction of tumor markers. Toxicity } \\
\text { was low in all patients }\end{array}$ & [247] \\
\hline $\begin{array}{l}14 \text { advanced } \\
\text { solid tumor } \\
\text { patients, affected } \\
\text { by thrombo- } \\
\text { cytopenia }\end{array}$ & Open trial & & $\begin{array}{l}\text { Melatonin was given p.o. at a daily } \\
\text { dose of } 40 \mathrm{mg} \text { at } 2000 \mathrm{~h} \text { starting } \\
7 \text { days before the onset of IL-2 } \\
\text { administration. IL- } 2 \text { was given s.c. at a } \\
\text { dose of } 3 \times 10^{6} \text { IU.m } \mathrm{m}^{2} \text { every } 12 \mathrm{~h} \text { for } 6 \\
\text { days/week for } 4 \text { weeks) }\end{array}$ & $\begin{array}{l}\text { Clinical outcome. } \\
\text { Platelet number }\end{array}$ & $\begin{array}{l}\text { A normalization of platelet number occurred } \\
\text { in } 10 / 14(71 \%) \text { patients, and platelet mean } \\
\text { number significantly increased on treatment. No } \\
\text { important therapy-related toxicity was observed }\end{array}$ & [248] \\
\hline $\begin{array}{l}40 \text { patients } \\
\text { with estrogen } \\
\text { receptor-negative } \\
\text { post-menopausal } \\
\text { metastatic breast } \\
\text { cancer patients }\end{array}$ & $\begin{array}{l}\text { Randomized } \\
\text { open trial }\end{array}$ & 1 year & $\begin{array}{l}\text { Patients were randomized to receive } \\
\text { tamoxifen alone }(20 \mathrm{mg} / \mathrm{day} \text { orally) or } \\
\text { tamoxifen plus melatonin }(20 \mathrm{mg} / \mathrm{day} \\
\text { p.o. in the evening) }\end{array}$ & Clinical outcome & $\begin{array}{l}\text { No complete response was seen. Partial } \\
\text { response rate was significantly higher in patients } \\
\text { treated with tamoxifen and melatonin than in } \\
\text { those receiving tamoxifen alone }(7 / 19 \text { vs } 2 / 21) \text {. } \\
\text { Percent of survival at } 1 \text { year was significantly } \\
\text { higher in patients treated with tamoxifen plus } \\
\text { melatonin than in those treated with tamoxifen } \\
\text { alone }(12 / 19 \text { vs } 5 / 21)\end{array}$ & {$[249]$} \\
\hline $\begin{array}{l}50 \text { patients } \\
\text { with metastatic } \\
\text { colorectal cancer }\end{array}$ & $\begin{array}{l}\text { Randomized } \\
\text { open trial }\end{array}$ & 1 year & $\begin{array}{l}\text { Patients were randomized to receive } \\
\text { supportive care alone or s.c IL-2 ( } 3 \\
\text { million IU/day for } 6 \text { days } / \text { week for } 4 \\
\text { weeks) plus melatonin ( } 40 \mathrm{mg} / \text { day } \\
\text { orally) }\end{array}$ & Clinical outcome & $\begin{array}{l}\text { No spontaneous tumor regression occurred } \\
\text { in patients receiving supportive care alone. A } \\
\text { partial response was achieved in } 3 / 25 \text { patients } \\
\text { treated with immunotherapy. Percent survival at } \\
1 \text { year was significantly higher in patients treated } \\
\text { with immunotherapy than in those treated with } \\
\text { supportive care alone }(9 / 25 \text { vs. } 3 / 25)\end{array}$ & {$[250]$} \\
\hline $\begin{array}{l}30 \text { patients with } \\
\text { glio-blastoma }\end{array}$ & $\begin{array}{l}\text { Randomized } \\
\text { open trial }\end{array}$ & 1 year & $\begin{array}{l}\text { Patients were randomized to receive } \\
\text { radiotherapy alone or radiotherapy } \\
\text { plus melatonin ( } 20 \mathrm{mg} / \text { daily orally) until } \\
\text { disease progression }\end{array}$ & Clinical outcome & $\begin{array}{l}\text { Both the survival curve and the percent of } \\
\text { survival at } 1 \text { year were significantly higher } \\
\text { in patients treated with radiotherapy plus } \\
\text { melatonin than in those receiving radiotherapy } \\
\text { alone }(6 / 14 \text { vs. } 1 / 16) \text {. Radiotherapy or steroid } \\
\text { therapy-related toxicities were lower in patients } \\
\text { concomitantly treated with melatonin }\end{array}$ & [251] \\
\hline $\begin{array}{l}116 \text { patients with } \\
\text { advanced solid } \\
\text { tumors }\end{array}$ & $\begin{array}{l}\text { Randomized } \\
\text { open trial }\end{array}$ & $1-5$ weeks & $\begin{array}{l}\text { Patients treated with IL-2 }\left(3 \times 10^{6} \mathrm{IU} /\right. \\
\text { day s.c. every day, } 6 \text { days/week for } \\
4 \text { weeks }) \text { or with TNF }(0.75 \mathrm{mg} / \text { day } \\
\text { i.v. for } 5 \text { days) were randomized to } \\
\text { receive or not a concomitant melatonin } \\
\text { administration ( } 40 \mathrm{mg} / \mathrm{day} \text { orally in } \\
\text { the evening, starting } 7 \text { days prior to } \\
\text { cytokine injection) }\end{array}$ & Clinical outcome & $\begin{array}{l}\text { The occurrence of hypotension was significantly } \\
\text { less frequent in patients concomitantly treated } \\
\text { by melatonin than in those who received the } \\
\text { cytokine alone, during either IL-2: or TNF } \\
\text { immunotherapy }\end{array}$ & [252] \\
\hline
\end{tabular}


Citation: Cardinali D, Escames G, Acuña-Castroviejo D, Ortiz F, Fernández-Gil B, et al. (2016) Melatonin-Induced Oncostasis, Mechanisms and Clinical Relevance. J Integr Oncol S1: 006. doi:10.4172/2329-6771.S1-006

Page 14 of 25

\begin{tabular}{|c|c|c|c|c|c|c|}
\hline Subjects & Design & $\begin{array}{l}\text { Study's } \\
\text { duration }\end{array}$ & Treatment & Measured & Results & Ref. \\
\hline $\begin{array}{l}100 \text { untreatable } \\
\text { metastatic solid } \\
\text { tumor patients }\end{array}$ & $\begin{array}{l}\text { Randomized } \\
\text { open trial }\end{array}$ & Variable & $\begin{array}{l}\text { Patients were randomized to receive } \\
\text { supportive care alone or supportive } \\
\text { care plus melatonin ( } 20 \mathrm{mg} / \text { daily p.o. in } \\
\text { the evening) until disease progression }\end{array}$ & $\begin{array}{l}\text { Clinical outcome. TNF } \\
\text { levels }\end{array}$ & $\begin{array}{l}\text { There were } 86 \text { evaluable patients, the other } 14 \\
\text { patients having died from rapid progression of } \\
\text { disease. The per cent of weight loss greater } \\
\text { than } 10 \% \text { was significantly higher in patients } \\
\text { treated by supportive care alone than in those } \\
\text { concomitantly treated by melatonin, with no } \\
\text { difference in food intake. Mean serum levels } \\
\text { of TNF significantly decreased in patients } \\
\text { concomitantly treated with melatonin }\end{array}$ & [253] \\
\hline $\begin{array}{l}25 \text { metastatic } \\
\text { solid tumor } \\
\text { patients other } \\
\text { than breast } \\
\text { cancer and } \\
\text { prostate cancer }\end{array}$ & $\begin{array}{l}\text { Phase II pilot } \\
\text { study }\end{array}$ & Variable & $\begin{array}{l}\text { Tamoxifen ( } 20 \mathrm{mg} / \text { day }) \text { and melatonin } \\
(20 \mathrm{mg} / \text { day) were given p.o. until } \\
\text { disease progression }\end{array}$ & Clinical outcome & $\begin{array}{l}\text { Three patients had a partial response }(12 \% \text {, one } \\
\text { cervix carcinoma; one melanoma; one unknown } \\
\text { primary tumor). A stable disease was achieved } \\
\text { in } 13 \text { other patients, whereas the remaining } \\
9 \text { patients progressed. Performance status } \\
\text { improved in } 9 / 25 \text { patients and a survival longer } \\
\text { than } 1 \text { year was observed in } 7 / 25 \text { patients }\end{array}$ & [254] \\
\hline $\begin{array}{l}30 \text { node-relapsed } \\
\text { melanoma } \\
\text { patients }\end{array}$ & $\begin{array}{l}\text { Randomized } \\
\text { open trial }\end{array}$ & 31 months & $\begin{array}{l}\text { Patients were randomized to receive } \\
\text { no treatment or melatonin ( } 20 \mathrm{mg} / \\
\text { daily p.o. in the evening) until disease } \\
\text { progression }\end{array}$ & & $\begin{array}{l}\text { The percent of disease-free survival was } \\
\text { significantly higher in melatonin-treated } \\
\text { individuals than in controls. No melatonin- } \\
\text { related toxicity was observed }\end{array}$ & [255] \\
\hline $\begin{array}{l}14 \text { metastatic } \\
\text { prostate } \\
\text { cancer patients } \\
\text { refractory to a } \\
\text { previous therapy } \\
\text { with LHRH } \\
\text { analogue }\end{array}$ & Open trial & $1-2$ years & $\begin{array}{l}\text { The LHRH analogue triptorelin was } \\
\text { injected i.m. at } 3.75 \mathrm{mg} \text { every } 28 \text { days. } \\
\text { Melatonin was given p.o at } 20 \mathrm{mg} / \\
\text { day in the evening every day until } \\
\text { progression, starting } 7 \text { days prior to } \\
\text { triptorelin }\end{array}$ & $\begin{array}{l}\text { Clinical outcome. Serum } \\
\text { levels of PSA, prolactin } \\
\text { and IGF-1 }\end{array}$ & $\begin{array}{l}\text { A survival longer than } 1 \text { year was achieved in } \\
9 / 14(64 \%) \text { patients. PSA mean concentrations } \\
\text { significantly decreased on therapy of triptorelin } \\
\text { plus melatonin. In addition, a normalization of } \\
\text { platelet number was obtained in } 3 / 5 \text { patients } \\
\text { with persistent thrombocytopenia prior to study }\end{array}$ & [256] \\
\hline $\begin{array}{l}70 \text { advanced } \\
\text { non-small cell } \\
\text { lung cancer } \\
\text { patients }\end{array}$ & $\begin{array}{l}\text { Randomized } \\
\text { open trial }\end{array}$ & 1 year & $\begin{array}{l}\text { Chemotherapy alone with cisplatin } \\
\left(20 \mathrm{mg} / \mathrm{m}^{2} / \text { day i.v. for } 3 \text { days }\right) \text { and } \\
\text { etoposide }\left(100 \mathrm{mg} / \mathrm{m}^{2} / \text { day i.v. for } 3\right. \\
\text { days) (Cycles were repeated at } 21- \\
\text { day intervals) or chemotherapy plus } \\
\text { melatonin }(20 \mathrm{mg} / \text { day orally in the } \\
\text { evening) }\end{array}$ & Clinical outcome & $\begin{array}{l}\text { A complete response was achieved in } 1 / 34 \\
\text { patients concomitantly treated with melatonin } \\
\text { and in none of the patients receiving } \\
\text { chemotherapy alone. Partial response } \\
\text { occurred in } 10 / 34 \text { and in } 6 / 36 \text { patients treated } \\
\text { with or without melatonin, respectively. The } \\
\text { percent of } 1 \text {-year survival was significantly } \\
\text { higher in patients treated with melatonin plus } \\
\text { chemotherapy than in those who received } \\
\text { chemotherapy alone (15/34 vs. } 7 / 36) \text {. } \\
\text { Chemotherapy was well tolerated in patients } \\
\text { receiving melatonin, and the frequency of } \\
\text { myelosuppression, neuropathy, and cachexia } \\
\text { was significantly lower in the melatonin group }\end{array}$ & [257] \\
\hline $\begin{array}{l}80 \text { patients with } \\
\text { metastatic solid } \\
\text { tumors who were } \\
\text { in poor clinical } \\
\text { condition (lung } \\
\text { cancer: } 35 ; \\
\text { breast cancer: } \\
31 \text {; gastro- } \\
\text { intestinal tract } \\
\text { tumors: } 14 \text { ) }\end{array}$ & $\begin{array}{l}\text { Randomized } \\
\text { open trial }\end{array}$ & Variable & $\begin{array}{l}\text { Lung cancer patients were treated } \\
\text { with cisplatin and etoposide, breast } \\
\text { cancer patients with mitoxantrone, and } \\
\text { gastrointestinal tract tumor patients } \\
\text { with } 5 \text {-FU plus folates. Patients were } \\
\text { randomized to receive chemotherapy } \\
\text { alone or chemotherapy plus melatonin } \\
(20 \text { mg/day p.o. in the evening) }\end{array}$ & Clinical outcome & $\begin{array}{l}\text { Thrombocytopenia was significantly less } \\
\text { frequent in patients concomitantly treated with } \\
\text { melatonin. Malaise, asthenia, stomatitis and } \\
\text { neuropathy were less frequent in the melatonin } \\
\text { group }\end{array}$ & [258] \\
\hline $\begin{array}{l}31 \text { patients with } \\
\text { advanced solid } \\
\text { tumors }\end{array}$ & & 3 months & $\begin{array}{l}\text { Melatonin ( } 10 \mathrm{mg} / \text { day p.o. in the } \\
\text { evening) }\end{array}$ & $\begin{array}{l}\text { Clinical outcome. Serum } \\
\text { levels of TNF-a, IL-1, IL- } \\
2, \text { IL-6 and IFN- } \gamma\end{array}$ & $\begin{array}{l}\text { After } 3 \text { months of therapy, } 19 \text { patients }(61 \%) \\
\text { showed disease progression. The other } \\
12(39 \%) \text { achieved disease stabilization. A } \\
\text { significant decrease of IL-6 circulating levels } \\
\text { was found }\end{array}$ & [259] \\
\hline $\begin{array}{l}50 \text { patients } \\
\text { suffering from } \\
\text { lung cancer, } \\
\text { gastro-intestinal } \\
\text { tract tumors, } \\
\text { breast cancer } \\
\text { or brain glio- } \\
\text { blastoma }\end{array}$ & & & $\begin{array}{l}\text { Melatonin alone }(20 \mathrm{mg} / \text { day orally in } \\
\text { the dark period }) \text { or melatonin plus aloe } \\
\text { vera tincture }(1 \mathrm{ml} \text { twice/day })\end{array}$ & Clinical outcome & $\begin{array}{l}\text { A partial response was achieved in } 2 / 24 \text { patients } \\
\text { treated with melatonin plus aloe and in none of } \\
\text { the patients treated with melatonin alone. Stable } \\
\text { disease was achieved in } 12 / 24 \text { and in } 7 / 26 \\
\text { patients treated with melatonin plus aloevera } \\
\text { or melatonin alone, respectively. The percent } \\
\text { 1-year survival was significantly higher in } \\
\text { patients treated with melatonin plus aloe vera }\end{array}$ & {$[260]$} \\
\hline
\end{tabular}


Citation: Cardinali D, Escames G, Acuña-Castroviejo D, Ortiz F, Fernández-Gil B, et al. (2016) Melatonin-Induced Oncostasis, Mechanisms and Clinical Relevance. J Integr Oncol S1: 006. doi:10.4172/2329-6771.S1-006

Page 15 of 25

\begin{tabular}{|c|c|c|c|c|c|c|}
\hline Subjects & Design & $\begin{array}{l}\text { Study's } \\
\text { duration }\end{array}$ & Treatment & Measured & Results & Ref. \\
\hline $\begin{array}{l}20 \text { previously } \\
\text { untreated } \\
\text { patients with } \\
\text { inoperable lung } \\
\text { cancer }\end{array}$ & $\begin{array}{l}\text { Double blind } \\
\text { placebo } \\
\text { controlled } \\
\text { study }\end{array}$ & 2 months & $\begin{array}{l}2 \text { cycles of carboplatin on day } 1 \text { and } \\
\text { etoposide on days } 1-3 \text { every } 4 \text { weeks. } \\
\text { Melatonin } 40 \text { mg or placebo (double- } \\
\text { blind) was given orally in the evening } \\
\text { for } 21 \text { consecutive days, starting } 2 \\
\text { days before chemotherapy. Patients } \\
\text { were randomized to receive melatonin } \\
\text { either with the first or the second cycle }\end{array}$ & $\begin{array}{l}\text { Hematologic } \\
\text { parameters }\end{array}$ & $\begin{array}{l}\text { The hematologic parameters--depth and } \\
\text { duration of toxicity for hemoglobin, platelets } \\
\text { and neutrophils were not significantly different } \\
\text { between cycles with/without melatonin }\end{array}$ & [261] \\
\hline $\begin{array}{l}14 \text { metastatic } \\
\text { breast cancer } \\
\text { women }\end{array}$ & Open trial & Variable & $\begin{array}{l}\text { Epirubicin. at weekly intervals. } \\
\text { Melatonin was given orally at } 20 \mathrm{mg} / \\
\text { day in the evening every day, starting } \\
7 \text { days prior to chemotherapy }\end{array}$ & $\begin{array}{l}\text { Clinical outcome. } \\
\text { Hematologicparameters }\end{array}$ & $\begin{array}{l}\text { Evaluable patients were } 12 / 14 \text {. The induction } \\
\text { phase with melatonin induced a normalization } \\
\text { of platelet number in } 9 / 12 \text { evaluable patients, } \\
\text { and no further platelet decline occurred in } \\
\text { chemotherapy. Objective tumor regression was } \\
\text { achieved in } 5 / 12(41 \%) \text { patients }\end{array}$ & [262] \\
\hline $\begin{array}{l}250 \text { metastatic } \\
\text { solid tumor } \\
\text { patients (lung } \\
\text { cancer, 104; } \\
\text { breast cancer, } \\
77 ; \text { gastro- } \\
\text { intestinal tract } \\
\text { neoplasms, 42; } \\
\text { head and neck } \\
\text { cancers, } 27 \text { ) }\end{array}$ & $\begin{array}{l}\text { Randomized } \\
\text { open trial }\end{array}$ & 1 year & $\begin{array}{l}\text { Chemotherapy consisted of cisplatin } \\
\text { plus etoposide or gemcitabine alone } \\
\text { for lung cancer, doxorubicin alone, } \\
\text { mitoxantrone alone or paclitaxel alone } \\
\text { for breast cancer, 5-FU plus folinic } \\
\text { acid for gastro-intestinal tumors and } \\
5 \text {-FU plus cisplatin for head and neck } \\
\text { cancers. Patients were randomized } \\
\text { to receive melatonin ( } 20 \text { mg/day p.o. } \\
\text { every day) plus chemotherapy, or } \\
\text { chemotherapy alone }\end{array}$ & Clinical outcome & $\begin{array}{l}\text { The 1-year survival rate and the objective tumor } \\
\text { regression rate were significantly higher in } \\
\text { patients concomitantly treated with melatonin } \\
\text { than in those who received chemotherapy alone } \\
\text { (tumor response rate: } 42 / 124 \text { chemotherapy } \\
+ \text { melatonin versus } 19 / 126 \text { chemotherapy } \\
\text { only; } 1 \text {-year survival: } 63 / 124 \text { chemotherapy + } \\
\text { melatonin versus } 29 / 126 \text { chemotherapy only). } \\
\text { Melatonin significantly reduced the frequency of } \\
\text { thrombocytopenia, neurotoxicity, cardiotoxicity, } \\
\text { stomatitis and asthenia }\end{array}$ & [263] \\
\hline $\begin{array}{l}30 \text { metastatic } \\
\text { renal cell cancer } \\
\text { patients under } \\
\text { chronic therapy } \\
\text { with morphine }\end{array}$ & $\begin{array}{l}\text { Randomized } \\
\text { open trial }\end{array}$ & 3 years & $\begin{array}{l}\text { Oral doses of morphine ranged from } \\
60 \text { to } 120 \mathrm{mg} / \text { day. Patients were } \\
\text { randomized to receive morphine alone } \\
\text { or morphine plus melatonin ( } 20 \mathrm{mg} / \\
\text { day p.o. in the evening). IL-2 was s.c. } \\
\text { administered at a dose of } 6 \text { million IU/ } \\
\text { day for } 6 \text { days/week for } 4 \text { consecutive } \\
\text { weeks. In non progressing patients, a } \\
\text { second cycle was planned after a } 21- \\
\text { day rest period }\end{array}$ & Clinical outcome & $\begin{array}{l}\text { The percent of partial responses achieved } \\
\text { in patients treated with morphine alone was } \\
\text { significantly lower than that observed in patients } \\
\text { concomitantly treated with melatonin }(1 / 16 \\
\text { vs. 4/14). The 3-year percent of survival was } \\
\text { significantly higher in patients concomitantly } \\
\text { treated with melatonin }\end{array}$ & [264] \\
\hline $\begin{array}{l}12 \text { advanced } \\
\text { hematologic } \\
\text { malignancies } \\
\text { which did not } \\
\text { respond to } \\
\text { previous standard } \\
\text { therapies } \\
\text { (non-Hodgkin's } \\
\text { lymphoma } \\
6 \text {; Hodgkin's } \\
\text { disease, } \\
2 \text {; multiple } \\
\text { myeloma, } 2 ; \\
\text { acute myelo- } \\
\text { genous leukemia, } \\
1 \text { and chronic } \\
\text { myelo-monocytic } \\
\text { leukemia, } 1 \text { ) }\end{array}$ & Open trial & 30 months & $\begin{array}{l}\text { IL-2 was s.c. administered at a dose } \\
\text { of } 3 \text { million IU/day for } 6 \text { days/week } \\
\text { for } 4 \text { consecutive weeks. Melatonin } \\
\text { was given orally at } 20 \mathrm{mg} / \text { day in the } \\
\text { evening, without interruption. In non- } \\
\text { progressing patients, a second IL-2 } \\
\text { cycle was planned after a } 3 \text { week-rest } \\
\text { period }\end{array}$ & Clinical outcome & $\begin{array}{l}\text { A partial response was achieved in one } \\
\text { patient with multiple myeloma. Stable disease } \\
\text { occurred in } 7 \text { other patients, whereas the other } \\
4 \text { patients progressed. The lack of progression } \\
\text { was obtained in } 8 \text { out of } 12(67 \%) \text { patients, } \\
\text { with a median duration of } 21+\text { months (14-30+ } \\
\text { months). The treatment was well tolerated in all } \\
\text { patients }\end{array}$ & [9] \\
\hline $\begin{array}{l}30 \text { patients with } \\
\text { cancer-related } \\
\text { thrombo- } \\
\text { cytopenia who } \\
\text { did not respond } \\
\text { to melatonin } \\
\text { alone }\end{array}$ & $\begin{array}{l}\text { Randomized } \\
\text { open trial }\end{array}$ & Variable & $\begin{array}{l}\text { Patients were randomized to receive } \\
\text { melatonin alone }(20 \mathrm{mg} / \mathrm{day} \text { orally } \\
\text { in the evening) or melatonin plus } \\
5 \text {-methoxytryptamine }(1 \mathrm{mg} / \text { day orally } \\
\text { in the early afternoon) }\end{array}$ & Hematologicparameters & $\begin{array}{l}\text { A normalization of platelet count was achieved } \\
\text { in } 5 / 14(36 \%) \text { patients treated with melatonin } \\
\text { plus 5-methoxytryptamine and in none of the } \\
\text { patients treated with melatonin alone. Mean } \\
\text { platelet number significantly increased only } \\
\text { in the patients treated with melatonin plus } \\
5 \text {-methoxytryptamine }\end{array}$ & [265] \\
\hline $\begin{array}{l}20 \text { metastatic } \\
\text { patients, who } \\
\text { progressed } \\
\text { on previous } \\
\text { antitumor } \\
\text { therapies }\end{array}$ & Open trial & 2 months & $\begin{array}{l}\text { Melatonin was given orally at } 20 \mathrm{mg} / \\
\text { day in the evening }\end{array}$ & $\begin{array}{l}\text { Clinical outcome. VEGF } \\
\text { levels in plasma }\end{array}$ & $\begin{array}{l}\text { The clinical response consisted of minor } \\
\text { response in } 2 \text {, stable disease in } 6 \text { and } \\
\text { progressive disease in the remaining } \\
12 \text { patients. Non-progressing patients } \\
\text { showed a significant decline in VEGF mean } \\
\text { concentrations, whereas no effect was achieved } \\
\text { in progressing patients }\end{array}$ & [266] \\
\hline
\end{tabular}


Citation: Cardinali D, Escames G, Acuña-Castroviejo D, Ortiz F, Fernández-Gil B, et al. (2016) Melatonin-Induced Oncostasis, Mechanisms and Clinical Relevance. J Integr Oncol S1: 006. doi:10.4172/2329-6771.S1-006

Page 16 of 25

\begin{tabular}{|c|c|c|c|c|c|c|}
\hline Subjects & Design & $\begin{array}{l}\text { Study's } \\
\text { duration }\end{array}$ & Treatment & Measured & Results & Ref. \\
\hline $\begin{array}{l}100 \text { patients } \\
\text { with inoperable } \\
\text { advanced primary } \\
\text { hepato-cellular } \\
\text { carcinoma }\end{array}$ & Open trial & 2 years & $\begin{array}{l}\text { Patients were treated separately } \\
\text { by transcatheter arterial } \\
\text { chemoembolization }(n=50) \\
\text { and by transcatheter arterial } \\
\text { chemoembolization }+ \text { melatonin }(20 \\
\text { mg/day at } 2000 \text { h orally, starting } 7 \\
\text { days before }(n=50)\end{array}$ & $\begin{array}{l}\text { Clinical outcome. IL-2 } \\
\text { and sIL-2R levels. }\end{array}$ & $\begin{array}{l}\text { The effectivity rates of transcatheter arterial } \\
\text { chemoembolization were significantly lower than } \\
\text { that of transcatheter arterial chemoembolization } \\
+ \text { melatonin. Melatonin protected liver function } \\
\text { from the damage caused by transcatheter } \\
\text { arterial chemoembolization. IL-2 levels of all } \\
\text { patients significantly increased, whereas sIL-2R } \\
\text { expressions decreased in the melatonin group }\end{array}$ & [267] \\
\hline $\begin{array}{l}13 \text { patients } \\
\text { with metastatic } \\
\text { melanoma } \\
\text { patients } \\
\text { progressing on } \\
\text { dacarbazine plus } \\
\text { IFN- } \alpha \text {. }\end{array}$ & Open trial & 1 year & $\begin{array}{l}\text { Cisplatin was injected i.v. for } 3 \text { days } \\
\text { every } 21 \text { days. IL-2 was administered } \\
\text { s.c. at } 3 \text { million IU/day from days } 4 \text { to } \\
9 \text { and from days } 11 \text { to } 16 \text { of the cycle. } \\
\text { Melatonin was given orally at } 20 \mathrm{mg} / \\
\text { day in the evening, every day without } \\
\text { interruption }\end{array}$ & Clinical outcome & $\begin{array}{l}\text { One patient obtained a complete response, } \\
\text { while a partial response was achieved in } 3 \\
\text { other patients. A stable disease occurred in } 5 \\
\text { patients, whereas the remaining } 4 \text { patients had } \\
\text { a progressive disease. The treatment was well- } \\
\text { tolerated and no cisplatin -related neurotoxicity } \\
\text { was observed }\end{array}$ & [268] \\
\hline $\begin{array}{l}14 \text { consecutive } \\
\text { untreatable } \\
\text { metastatic solid } \\
\text { tumor patients }\end{array}$ & $\begin{array}{l}\text { Cross-over } \\
\text { randomized } \\
\text { study }\end{array}$ & Variable & $\begin{array}{l}\text { Two consecutive immunotherapeutic } \\
\text { cycles at } 21 \text {-day intervals with IL-2 } \\
\text { plus melatonin alone or with IL-2 plus } \\
\text { melatonin ( } 20 \mathrm{mg} / \text { day) and naltrexone } \\
\text { (100 mg in the morning every next day) }\end{array}$ & $\begin{array}{l}\text { Hematologic } \\
\text { parameters }\end{array}$ & $\begin{array}{l}\text { The association of naltrexone further amplifies } \\
\text { the lymphocytosis obtained after IL-2 plus } \\
\text { melatonin }\end{array}$ & [269] \\
\hline $\begin{array}{l}30 \text { patients } \\
\text { with metastatic } \\
\text { colorectal cancer }\end{array}$ & $\begin{array}{l}\text { Randomized } \\
\text { open trial }\end{array}$ & 1 year & $\begin{array}{l}\text { Patients were randomized to be } \\
\text { treated with irinotecan alone for } 9 \\
\text { consecutive weeks or irinotecan plus } \\
\text { melatonin }(20 \mathrm{mg} / \text { day })\end{array}$ & Clinical outcome & $\begin{array}{l}\text { No complete response was observed. A partial } \\
\text { response (was achieved in } 2 \text { out of } 16 \text { patients } \\
\text { treated with irinotecan alone and in } 5 \text { out of } 14 \\
\text { patients concomitantly treated with melatonin. } \\
\text { Percent of disease-control achieved in patients } \\
\text { concomitantly treated with melatonin was } \\
\text { significantly higher than that observed in those } \\
\text { treated with chemotherapy alone }\end{array}$ & [270] \\
\hline $\begin{array}{l}100 \text { consecutive } \\
\text { metastatic non- } \\
\text { small cell lung } \\
\text { cancer patients }\end{array}$ & $\begin{array}{l}\text { Randomized } \\
\text { open trial }\end{array}$ & 5 years & $\begin{array}{l}\text { Patients were randomized to } \\
\text { receive chemotherapy (cisplatin and } \\
\text { etoposide) alone or chemotherapy and } \\
\text { melatonin ( } 20 \mathrm{mg} / \text { day). }\end{array}$ & Clinical outcome & $\begin{array}{l}\text { Both the overall tumor regression rate and } \\
\text { the } 5 \text {-year survival results were significantly } \\
\text { higher in patients concomitantly treated with } \\
\text { melatonin. In particular, no patient treated with } \\
\text { chemotherapy alone was alive after } 2 \text { years, } \\
\text { whereas a 5-year survival was achieved in three } \\
\text { of } 49(6 \%) \text { patients treated with chemotherapy } \\
\text { and melatonin. Chemotherapy was better } \\
\text { tolerated in patients treated with melatonin }\end{array}$ & [271] \\
\hline $\begin{array}{l}24 \text { patients } \\
\text { not amenable } \\
\text { to standard } \\
\text { anticancer } \\
\text { treatment and } \\
\text { with weight loss } \\
\text { and/or decreased } \\
\text { serum albumin }\end{array}$ & Open trial & 8 weeks & $\begin{array}{l}4.9 \mathrm{~g} \text { of eicosapentaenoic acid and } 3.2 \\
\mathrm{~g} \text { of docosahexanoic acid, or } 18 \mathrm{mg} / \\
\text { day of melatonin for } 4 \text { weeks }\end{array}$ & $\begin{array}{l}\text { Serum or plasma } \\
\text { TNF- } \alpha, \text { IL } 1 \beta, \text { sIL2R. IL- } \\
6, \text { IL- } 8 \text { and specific fatty } \\
\text { acid levels }\end{array}$ & $\begin{array}{l}\text { Serum levels of fatty acids increased with } \\
\text { fish oil. No major changes in biochemical } \\
\text { variables and cytokines were observed with } \\
\text { any intervention. In the fish oil group, } 5 \text { of } 13 \\
\text { patients }(38 \%) \text { showed weight stabilization or } \\
\text { gain compared with } 3 \text { of } 11 \text { patients }(27 \%) \text { in the } \\
\text { melatonin group. After combining interventions, } \\
\text { approximately } 63 \% \text { of patients showed such } \\
\text { responses }\end{array}$ & [272] \\
\hline $\begin{array}{l}370 \text { metastatic } \\
\text { solid tumor } \\
\text { patients, suffering } \\
\text { from non-small } \\
\text { cell lung cancer } \\
\text { or gastro- } \\
\text { intestinal tumors }\end{array}$ & $\begin{array}{l}\text { Randomized } \\
\text { open trial }\end{array}$ & 2 years & $\begin{array}{l}\text { Patients were randomized to receive } \\
\text { chemotherapy alone or chemotherapy } \\
\text { plus melatonin ( } 20 \mathrm{mg} / \text { day orally in the } \\
\text { evening every day) }\end{array}$ & Clinical outcome & $\begin{array}{l}\text { The overall tumor regression rate achieved in } \\
\text { patients concomitantly treated with melatonin } \\
\text { was significantly higher than that found in those } \\
\text { treated with chemotherapy alone. The 2-year } \\
\text { survival rate was significantly higher in patients } \\
\text { concomitantly treated with melatonin }\end{array}$ & [273] \\
\hline $\begin{array}{l}126 \text { Radiation } \\
\text { Therapy } \\
\text { Oncology } \\
\text { Group recursive } \\
\text { partitioning } \\
\text { analysis Class } \\
2 \text { patients with } \\
\text { brain metastases }\end{array}$ & $\begin{array}{l}\text { Phase II } \\
\text { randomized } \\
\text { trial }\end{array}$ & Variable & $\begin{array}{l}\text { Class } 2 \text { patients with brain metastases } \\
\text { were randomized to } 20 \mathrm{mg} \text { of } \\
\text { melatonin, given either in the morning } \\
\text { or in the evening. All patients received } \\
\text { radiation therapy in the afternoon. } \\
\text { Melatonin was continued until } \\
\text { neurologic deterioration or death }\end{array}$ & Clinical outcome & $\begin{array}{l}\text { Neither of the randomized groups had survival } \\
\text { distributions that differed significantly from the } \\
\text { historic controls of patients treated with whole- } \\
\text { brain radiotherapy }\end{array}$ & [206] \\
\hline $\begin{array}{l}846 \text { patients } \\
\text { with metastatic } \\
\text { solid tumor (non- } \\
\text { small cell lung } \\
\text { cancer or gastro- } \\
\text { intestinal tract } \\
\text { tumors) }\end{array}$ & $\begin{array}{l}\text { Randomized } \\
\text { open trial }\end{array}$ & 3 years & $\begin{array}{l}\text { Patients were randomized to receive } \\
\text { the best supportive care only, } \\
\text { supportive care plus melatonin ( } 20 \\
\text { mg/day, orally in the evening), or } \\
\text { melatonin plus supportive care plus a } \\
\text { low-dose pf IL-2 for } 5 \text { days/week, for } 4 \\
\text { consecutive weeks }\end{array}$ & Clinical outcome & $\begin{array}{l}\text { Melatonin alone was able to induce a significant } \\
\text { increase of disease stabilization and survival } \\
\text { time with respect to supportive care alone. The } \\
\text { association of IL- } 2 \text { with melatonin provided a } \\
\text { further improvement in the percentage of tumor } \\
\text { regressions and of 3-year survival with respect } \\
\text { to melatonin alone }\end{array}$ & [274] \\
\hline
\end{tabular}


Citation: Cardinali D, Escames G, Acuña-Castroviejo D, Ortiz F, Fernández-Gil B, et al. (2016) Melatonin-Induced Oncostasis, Mechanisms and Clinical Relevance. J Integr Oncol S1: 006. doi:10.4172/2329-6771.S1-006

Page 17 of 25

\begin{tabular}{|c|c|c|c|c|c|c|}
\hline Subjects & Design & $\begin{array}{l}\text { Study's } \\
\text { duration }\end{array}$ & Treatment & Measured & Results & Ref. \\
\hline $\begin{array}{l}20 \text { consecutive } \\
\text { patients, who } \\
\text { underwent pelvic } \\
\text { irradiation }\end{array}$ & $\begin{array}{l}\text { Randomized } \\
\text { open trial }\end{array}$ & & $\begin{array}{l}\text { The patients were randomized } \\
\text { to be concomitantly treated with } \\
\text { melatonin alone, with melatonin plus } \\
\text { 5-mthoxytryptamine or with s.c. low- } \\
\text { dose IL-2 }\end{array}$ & Hematologicparameters & $\begin{array}{l}\text { Radiotherapy induced a significant decline } \\
\text { in the mean number of lymphocytes while } \\
\text { neither melatonin alone, nor melatonin plus } \\
5 \text {-methoxytryptamine were able to significantly } \\
\text { reduce this decline. }\end{array}$ & [275] \\
\hline $\begin{array}{l}14 \text { untreatable } \\
\text { metastatic cancer } \\
\text { patients showing } \\
\text { alterations of } \\
\text { cortisol rhythm }\end{array}$ & Open trial & 3 months & $\begin{array}{l}\text { Melatonin at } 20 \mathrm{mg} / \text { day orally in the } \\
\text { evening }\end{array}$ & $\begin{array}{l}\text { Clinical outcome. } \\
\text { Plasma cortisol rhythm. }\end{array}$ & $\begin{array}{l}\text { Normalization of cortisol rhythm was achieved in } \\
4 / 14(29 \%) \text { patients. Moreover, stable disease } \\
\text { was obtained in } 6 / 14(43 \%) \text { patients under } \\
\text { melatonin therapy, whereas the other } 8 \text { patients } \\
\text { had progressive disease. The percentage } \\
\text { of cortisol rhythm normalization achieved in } \\
\text { patients with stable disease was significantly } \\
\text { higher than that observed in patients with } \\
\text { progressive disease }\end{array}$ & [276] \\
\hline $\begin{array}{l}20 \text { patients with } \\
\text { untreatable } \\
\text { metastatic solid } \\
\text { tumor }\end{array}$ & Open trial & 1 year & $\begin{array}{l}\text { Melatonin at } 20 \mathrm{mg} / \text { day orally in the } \\
\text { evening }\end{array}$ & Immune paramters & $\begin{array}{l}\text { Melatonin induced a statistically significant } \\
\text { decline in mean T-reg cell numbers in patients } \\
\text { who achieved disease control, whereas no } \\
\text { effect was seen in those who had progressed. } \\
\text { No in vitro effect of melatonin incubation was } \\
\text { apparent }\end{array}$ & [277] \\
\hline $\begin{array}{l}95 \text { post- } \\
\text { menopausal } \\
\text { women with } \\
\text { a prior history } \\
\text { of stages } 0 \text {-III } \\
\text { breast cancer } \\
\text { who had } \\
\text { completed active } \\
\text { cancer treatment }\end{array}$ & $\begin{array}{l}\text { Double-blind, } \\
\text { placebo- } \\
\text { controlled } \\
\text { study }\end{array}$ & 4 months & $\begin{array}{l}\text { Patients were randomly assigned to } \\
\text { either } 3 \mathrm{mg} \text { oral melatonin }(n=48) \text { or } \\
\text { placebo daily for } 4 \text { months }\end{array}$ & $\begin{array}{l}\text { Compliance and } \\
\text { change in breast cancer } \\
\text { biomarkers (estradiol, } \\
\text { IGF-1, IGF-binding } \\
\text { protein } 3 \text { and the IGF-1/ } \\
\text { IGFBP-3 ratio }\end{array}$ & $\begin{array}{l}\text { Short-term melatonin treatment did not influence } \\
\text { the estradiol and IGF-1/IGBBP-3 levels }\end{array}$ & [207] \\
\hline $\begin{array}{l}\text { Patients with } \\
\text { advanced lung or } \\
\text { gastro-intestinal } \\
\text { cancer and } \\
\text { cachexia }\end{array}$ & $\begin{array}{l}\text { Double-blind, } \\
\text { placebo- } \\
\text { controlled } \\
\text { study }\end{array}$ & 28 days & Melatonin $20 \mathrm{mg}$ p.o. versus placebo & Clinical outcome & $\begin{array}{l}\text { After interim analysis of } 48 \text { patients, the study } \\
\text { was closed for futility. There were no significant } \\
\text { differences between groups for appetite or other } \\
\text { symptoms, weight, toxicity, or survival from } \\
\text { baseline to day } 28\end{array}$ & [208] \\
\hline $\begin{array}{l}\text { Advanced, non- } \\
\text { small cell lung } \\
\text { cancer }\end{array}$ & $\begin{array}{l}\text { Double-blind, } \\
\text { placebo- } \\
\text { controlled } \\
\text { study }\end{array}$ & 7 months & $\begin{array}{l}\text { Patients were randomized to receive } \\
10 \mathrm{mg} \text { or } 20 \mathrm{mg} \text { of melatonin p.o. or } \\
\text { placebo. }\end{array}$ & $\begin{array}{l}\text { Assessment of } \\
\text { health-related quality } \\
\text { of life (HRQoL) was } \\
\text { completed at baseline, } \\
\text { and at } 2,3 \text { and } 7 \\
\text { months. DNA damage } \\
\text { was measured during } \\
\text { the first three months of } \\
\text { chemo-therapy }\end{array}$ & $\begin{array}{l}\text { Patients in the melatonin-treated group had } \\
\text { significantly better HRQoL scores, particularly } \\
\text { in social well-being. Median survival was } 7.3 \\
\text { months in the two groups. A greater amount } \\
\text { of DNA damage marker was observed in the } \\
\text { placebo-treated group, and this was associated } \\
\text { with lower survival. }\end{array}$ & [196] \\
\hline $\begin{array}{l}54 \text { women } \\
\text { undergoing } \\
\text { surgery for breast } \\
\text { cancer and } \\
\text { without signs of } \\
\text { depression on } \\
\text { Major Depression } \\
\text { Inventory (MDI) }\end{array}$ & $\begin{array}{l}\text { Double-blind, } \\
\text { placebo- } \\
\text { controlled } \\
\text { study }\end{array}$ & 3 months & $6 \mathrm{mg}$ of melatonin p.o. or placebo & $\begin{array}{l}\text { The primary outcome } \\
\text { was the incidence of } \\
\text { depressive symptoms } \\
\text { measured by MDI. }\end{array}$ & $\begin{array}{l}\text { The risk of developing depressive symptoms } \\
\text { was significantly lower with melatonin than with } \\
\text { placebo }\end{array}$ & [195] \\
\hline $\begin{array}{l}95 \text { post- } \\
\text { menopausal } \\
\text { women with a } \\
\text { prior history of } \\
\text { stage } 0 \text {-III breast } \\
\text { cancer }\end{array}$ & $\begin{array}{l}\text { Placebo } \\
\text { controlled } \\
\text { study }\end{array}$ & 4 months & $3 \mathrm{mg}$ of melatonin or placebo & $\begin{array}{l}\text { Pittsburgh Sleep } \\
\text { Quality Index (PSQI). } \\
\text { Depression and hot } \\
\text { flash assessment. }\end{array}$ & $\begin{array}{l}\text { Compared to subjects on placebo, subjects } \\
\text { randomized to melatonin experienced } \\
\text { significantly greater improvements in subjective } \\
\text { sleep quality as measured by the PSQI, } \\
\text { including domains on sleep quality, daytime } \\
\text { dysfunction and total score. There were } \\
\text { no significant differences in measures of } \\
\text { depression or hot flashes }\end{array}$ & [171] \\
\hline
\end{tabular}

5-FU: 5-fluorouracil; i.m. intramuscularly; IFN: interferon; IGF: insulin-like growth factor; IL: Interleukin; NK : natural killer; p.o. per os; PSA: prostatic specific antigen; s.c. subcutaneous; sIL-2R: soluble IL-2 receptor; TNF : tumor necrosis factor; VEGF: Vascular endothelial growth factor.

Table 2: Effect of Melatonin in Cancer Patients.

of the randomized groups had survival distributions that differed significantly from the historic controls of patients treated with wholebrain radiotherapy [206]. In 95 post-menopausal women with a prior history of stages 0 -III breast cancer who had completed active cancer treatment, a double-blind, placebo-controlled study with either $3 \mathrm{mg}$ oral melatonin or placebo daily for 4 months, melatonin treatment did not affect breast cancer biomarkers [207]. In a double-blind, placebo- controlled study in patients with advanced lung or gastro-intestinal cancer and cachexia, melatonin $(20 \mathrm{mg} /$ day $)$ was ineffective to modify appetite, weight, toxicity, or survival from baseline to day 28 [208].

\section{Conclusion}

Melatonin can provide an innovative adjuvant strategy in cancer by combining their effects on the circadian rhythm with their oncostatic 
and cytoprotective properties. As discussed in the present review article melatonin is effective in suppressing neoplastic growth in a variety of tumors. The mechanisms involved include antiproliferative effects via modulation of cell cycle, ability to induce apoptosis in cancer cells, anti-angiogenic and antimetastatic effects, anti-estrogenic activity, the capacity to decrease telomerase activity, immune modulation, and direct and indirect antioxidant effects. Besides these oncostatic properties, melatonin deserves to be considered in the treatment of cancer for two other reasons. First, because its hypnotic-chronobiotic properties, melatonin use that can allow the clinician to effectively address sleep disturbances, a major co-morbidity in cancer. Indeed as with many other diseases, evidence supports the hypothesis that metabolic rhythms attenuation and / or disruption contribute to the etiology of cancer. Second, because melatonin's anxiolytic and antidepressant effects, it has a possible application in two other major co-morbidities seen in cancer patients, i.e. depression and anxiety.

An important remaining question to be considered is the melatonin dose employed. From the basis aspects of melatonin activity discussed in previous sections of this article, it emerges the necessity to employ melatonin doses in the $100-500 \mathrm{mg}$ /day range to produce full expression of cytoprotection in experimental cancer models. Indeed, melatonin has a high safety profile, it is usually remarkably well tolerated and, in some studies, it has been administered to patients at very large doses. Escalating doses of melatonin up to $100 \mathrm{mg}$ were devoid of undesirable activity in humans [209,210]. Melatonin $(300 \mathrm{mg} /$ day for up to 3 years) decreased oxidative stress in patients with amyotrophic lateral sclerosis [211] with very few undesirable side effects. In children with muscular dystrophy, $70 \mathrm{mg} /$ day of melatonin reduced cytokines and lipid peroxidation [212]. Doses of $80 \mathrm{mg}$ melatonin hourly for 4 $\mathrm{h}$ were given to healthy men with no undesirable effects other than drowsiness [213]. In healthy women given $300 \mathrm{mg}$ melatonin/day for 4 months there were no side effects [214]. In a randomized controlled double-blind clinical trial on 50 patients referred for liver surgery a single preoperative enteral dose of $50 \mathrm{mg} / \mathrm{kg}$ melatonin was safe and well tolerated [215]. This underlines the urgent need for large clinical trials in the field of melatonin and cancer [216,217].

\section{Financial Support and Grants}

PICT 200701045 and 20120984 from the Agencia Nacional de Promoción Científica y Tecnológica, Argentina; SAF2009-14037 and SAF SAF2013-49019 from the Spanish Ministry of Economy and Competitivity (MINECO); GREIB PT_2010_04 from the CEIBiotic Program of the University of Granada, Spain; RD12/0043/0005 (RETICEF) from the Instituto de Salud Carlos III, Spain, and CTS101 from the Consejería de Innovación, Ciencia y Empresa, Junta de Andalucía, Spain. The authors declare having no financial, consulting, or personal relationships with people or organizations that could be perceived as influencing their work.

\section{References}

1. Hardeland R, Cardinali DP, Srinivasan V, Spence DW, Brown GM, et al. (2011) Melatonin--a pleiotropic, orchestrating regulator molecule. Prog Neurobiol 93 : 350-384

2. Miller SC, Pandi-Perumal SR, Esquifino AI, Cardinali DP, Maestroni GJ (2006) The role of melatonin in immuno-enhancement: potential application in cancer. Int J Exp Pathol 87: 81-87.

3. Srinivasan V, Spence DW, Pandi-Perumal SR, Trakht I, Cardinali DP (2008) Therapeutic actions of melatonin in cancer: possible mechanisms. Integr Cancer Ther 7: 189-203.

4. Srinivasan V, Pandi-Perumal SR, Brzezinski A, Bhatnagar KP, Cardinali DP (2011) Melatonin, immune function and cancer. Recent Pat Endocr Metab Immune Drug Discov 5: 109-123.
5. Rondanelli M, Faliva MA Perna S, Antoniello N (2013) Update on the role of melatonin in the prevention of cancer tumorigenesis and in the management of cancer correlates, such as sleep-wake and mood disturbances: review and remarks. Aging Clin Exp Res 25: 499-510.

6. Bizzarri M, Proietti S, Cucina A, Reiter RJ (2013) Molecular mechanisms of the pro-apoptotic actions of melatonin in cancer: a review. Expert Opin Ther Targets 17: 1483-1496.

7. Korkmaz A, Sanchez-Barcelo EJ, Tan DX, Reiter RJ (2009) Role of melatonin in the epigenetic regulation of breast cancer. Breast Cancer Res Treat 115 13-27

8. Reiter RJ, Tan DX, Erren TC, Fuentes-Broto L, Paredes SD (2009) Lightmediated perturbations of circadian timing and cancer risk: a mechanistic analysis. Integr Cancer Ther 8: 354-360.

9. Lissoni P, Bolis S, Brivio F, Fumagalli L (2000) A phase II study of neuroimmunotherapy with subcutaneous low-dose IL-2 plus the pineal hormone melatonin in untreatable advanced hematologic malignancies. Anticancer Res 20: $2103-2105$

10. Trubiani O, Recchioni R, Moroni F, Pizzicannella J, Caputi S, et al. (2005) Melatonin provokes cell death in human B-lymphoma cells by mitochondrialdependent apoptotic pathway activation. J Pineal Res 39: 425-431.

11. Bejarano I, Redondo PC, Espino J, Rosado JA, Paredes SD, et al. (2009) Melatonin induces mitochondrial-mediated apoptosis in human myeloid $\mathrm{HL}-60$ cells. J Pineal Res 46: 392-400.

12. Sánchez-Hidalgo $M$, Lee $M$, de la Lastra CA, Guerrero JM, Packham G (2012) Melatonin inhibits cell proliferation and induces caspase activation and apoptosis in human malignant lymphoid cell lines. J Pineal Res 53: 366-373.

13. Liu L, Xu Y, Reiter RJ (2013) Melatonin inhibits the proliferation of human osteosarcoma cell line MG-63. Bone 55: 432-438.

14. Glenister R, McDaniel K, Francis H, Venter J, Jensen K, et al. (2013) Therapeutic actions of melatonin on gastrointestinal cancer development and progression. Transl Gastrointest Cancer.

15. Hong Y, Won J, Lee Y, Lee S, Park K, et al. (2014) Melatonin treatment induces interplay of apoptosis, autophagy, and senescence in human colorectal cancer cells. J Pineal Res 56: 264-274.

16. Mediavilla MD, Sanchez-Barcelo EJ, Tan DX, Manchester L, Reiter RJ (2010) Basic mechanisms involved in the anti-cancer effects of melatonin. Curr Med Chem 17: 4462-4481.

17. Codenotti S, Battistelli M, Burattini S, Salucci S, Falcieri E, et al. (2015) Melatonin decreases cell proliferation, impairs myogenic differentiation and triggers apoptotic cell death in rhabdomyosarcoma cell lines. Oncol Rep 34 279-287.

18. Martín V, Herrera F, Carrera-Gonzalez P, García-Santos G, Antolín I, et al. (2006) Intracellular signaling pathways involved in the cell growth inhibition of glioma cells by melatonin. Cancer Res 66: 1081-1088.

19. Martín V, Herrera F, García-Santos G, Antolín I, Rodriguez-Blanco J, et al. (2007) Involvement of protein kinase C in melatonin's oncostatic effect in C6 glioma cells. J Pineal Res 43: 239-244.

20. Pizarro JG, Yeste-Velasco M, Esparza JL, Verdaguer E, Pallas M, et al. (2008) The antiproliferative activity of melatonin in B65 rat dopaminergic neuroblastoma cells is related to the downregulation of cell cycle-related genes. J Pineal Res 45: 8-16.

21. Harbour JW, Luo RX, Dei SA, Postigo AA, Dean DC (1999) Cdk phosphorylation triggers sequential intramolecular interactions that progressively block $\mathrm{Rb}$ functions as cells move through G1. Cell 98: 859-869.

22. Cini G, Neri B, Pacini A, Cesati V, Sassoli C, et al. (2005) Antiproliferative activity of melatonin by transcriptional inhibition of cyclin D1 expression: a molecular basis for melatonin-induced oncostatic effects. J Pineal Res 39: 1220.

23. Loureiro R, Magalhaes-Novais S, Mesquita KA, Baldeiras I, Sousa IS, et al. (2015) Melatonin antiproliferative effects require active mitochondrial function in embryonal carcinoma cells. Oncotarget 6: 17081-17096.

24. Martín-Renedo J, Mauriz JL, Jorquera F, Ruiz-Andrés O, González P, et al (2008) Melatonin induces cell cycle arrest and apoptosis in hepatocarcinoma HepG2 cell line. J Pineal Res 45: 532-540.

25. Luchetti F, Betti M, Canonico B, Arcangeletti M, Ferri P, et al. (2009) ERK 
Citation: Cardinali D, Escames G, Acuña-Castroviejo D, Ortiz F, Fernández-Gil B, et al. (2016) Melatonin-Induced Oncostasis, Mechanisms and Clinical Relevance. J Integr Oncol S1: 006. doi:10.4172/2329-6771.S1-006

Page 19 of 25

MAPK activation mediates the antiapoptotic signaling of melatonin in UVB stressed U937 cells. Free Radic Biol Med 46: 339-351.

26. Cabrera J, Negrín G, Estévez F, Loro J, Reiter RJ, et al. (2010) Melatonin decreases cell proliferation and induces melanogenesis in human melanoma SK-MEL-1 cells. J Pineal Res 49: 45-54.

27. Densham RM, Todd DE, Balmanno K, Cook SJ (2008) ERK1/2 and p38 cooperate to delay progression through $\mathrm{G} 1$ by promoting cyclin D1 protein turnover. Cell Signal 20: 1986-1994.

28. Proietti S, Cucina A, D'Anselmi F, Dinicola S, Pasqualato A, et al. (2011) Melatonin and vitamin D3 synergistically down-regulate Akt and MDM2 leading to TGFbeta-1-dependent growth inhibition of breast cancer cells. J Pineal Res 50: $150-158$

29. Amornphimoltham P, Patel V, Sodhi A, Nikitakis NG, Sauk JJ, et al. (2005) Mammalian target of rapamycin, a molecular target in squamous cell carcinomas of the head and neck. Cancer Res 65: 9953-9961.

30. Brazil DP, Yang ZZ, Hemmings BA (2004) Advances in protein kinase B signalling: AKTion on multiple fronts. Trends Biochem Sci 29: 233-242.

31. Jung JH, Sohn EJ, Shin EA, Lee D, Kim B, et al. (2013) Melatonin Suppresses the Expression of 45S Preribosomal RNA and Upstream Binding Factor and Enhances the Antitumor Activity of Puromycin in MDA-MB-231 Breast Cance Cells. Evid Based Complement Alternat Med 2013: 879746.

32. Liu C, Jia Z, Zhang X, Hou J, Wang L, et al. (2012) Involvement of melatonin in autophagy-mediated mouse hepatoma H22 cell survival. Int Immunopharmacol 12: $394-401$

33. Chuffa LG, Fioruci-Fontanelli BA, Mendes LO, Ferreira Seiva FR, Martinez M, et al. (2015) Melatonin attenuates the TLR4-mediated inflammatory response through MyD88- and TRIF-dependent signaling pathways in an in vivo model of ovarian cancer. BMC Cancer 15: 34

34. Ghosh S, Karin M (2002) Missing pieces in the NF-kappaB puzzle. Cell 109 S81-S96.

35. Kang CH, Chiang PH, Huang SC (2008) Correlation of COX-2 expression in stromal cells with high stage, high grade, and poor prognosis in urothelial carcinoma of upper urinary tracts. Urology 72: 153-157.

36. Wang J, Xiao X, Zhang Y, Shi D, Chen W, et al. (2012) Simultaneous modulation of COX-, p300, Akt, and Apaf-1 signaling by melatonin to inhibit proliferation and induce apoptosis in breast cancer cells. J Pineal Res 53: 77-90.

37. Culig Z, Hobisch A, Cronauer MV, Radmayr C, Hittmair A, et al. (1996) Regulation of prostatic growth and function by peptide growth factors. Prostate 28: $392-405$

38. Blask DE, Sauer LA, Dauchy RT (2002) Melatonin as a chronobiotic/anticance agent: cellular, biochemical, and molecular mechanisms of action and their implications for circadian-based cancer therapy. Curr Top Med Chem 2: 113132.

39. Rasmussen CD, Means AR (1987) Calmodulin is involved in regulation of cell proliferation. EMBO J 6: 3961-3968.

40. Hill SM, Belancio VP, Dauchy RT, Xiang S, Brimer S, et al. (2015) Melatonin: an inhibitor of breast cancer. Endocr Relat Cancer 22: R183-R204.

41. Episkopou V (2005) SOX2 functions in adult neural stem cells. Trends Neurosci 28: $219-221$

42. Wan F, Herold-Mende C, Campos B, Centner FS, Dictus C, et al. (2011) Association of stem cell-related markers and survival in astrocytic gliomas. Biomarkers 16: 136-143.

43. Yu CC, Lo WL, Chen YW, Huang PI, Hsu HS, et al. (2011) Bmi-1 Regulates Snail Expression and Promotes Metastasis Ability in Head and Neck Squamous Cancer-Derived ALDH1 Positive Cells. J Oncol.

44. Yang S, Zheng J, Ma Y, Zhu H, Xu T, et al. (2012) Oct4 and Sox2 are overexpressed in human neuroblastoma and inhibited by chemotherapy. Onco Rep 28: 186-192.

45. Qu J, Rizak JD, Li X, Li J, Ma Y (2013) Melatonin treatment increases the transcription of cell proliferation-related genes prior to inducing cell death in C6 glioma cells. Oncol Lett 6: 347-352.

46. Zhang S, Zuo L, Gui S, Zhou Q, Wei W, et al. (2012) Induction of cell differentiation and promotion of endocan gene expression in stomach cancer by melatonin. Mol Biol Rep 39: 2843-2849.
47. Yu Q, Miller SC, Osmond DG (2000) Melatonin inhibits apoptosis during early B-cell development in mouse bone marrow. J Pineal Res 29: 86-93.

48. Jou MJ, Peng TI, Yu PZ, Jou SB, Reiter RJ, et al. (2007) Melatonin protects against common deletion of mitochondrial DNA-augmented mitochondrial oxidative stress and apoptosis. J Pineal Res 43: 389-403.

49. Rubio S, Estévez F, Cabrera J, Reiter RJ, Loro J, et al. (2007) Inhibition of proliferation and induction of apoptosis by melatonin in human myeloid HL-60 cells. J Pineal Res 42: 131-138.

50. García-Navarro A, González-Puga C, Escames G, López LC, López A, et al. (2007) Cellular mechanisms involved in the melatonin inhibition of HT-29 human colon cancer cell proliferation in culture. J Pineal Res 43: 195-205.

51. Yang QH, Xu JN, Xu RK, Pang SF (2007) Antiproliferative effects of melatonin on the growth of rat pituitary prolactin-secreting tumor cells in vitro. J Pineal Res 42: 172-179.

52. Joo SS, Yoo YM (2009) Melatonin induces apoptotic death in LNCaP cells via p38 and JNK pathways: therapeutic implications for prostate cancer. J Pineal Res 47: 8-14.

53. Zhang S, Qi Y, Zhang H, He W, Zhou Q, et al. (2013) Melatonin inhibits cell growth and migration, but promotes apoptosis in gastric cancer cell line, SGC7901. Biotech Histochem 88: 281-289.

54. Ecke TH, Schlechte HH, Hübsch A, Lenk SV, Schiemenz K, et al. (2007) TP53 mutation in prostate needle biopsies--comparison with patients follow-up. Anticancer Res 27: 4143-4148.

55. Brady CA, Attardi LD (2010) p53 at a glance. J Cell Sci 123: 2527-2532.

56. Mediavilla MD, Cos S, Sanchez-Barcelo EJ (1999) Melatonin increases p53 and p21WAF1 expression in MCF-7 human breast cancer cells in vitro. Life Sci 65: 415-420.

57. Gupta K, Thakur VS, Bhaskaran N, Nawab A, Babcook MA, et al. (2012) Green tea polyphenols induce p53-dependent and p53-independent apoptosis in prostate cancer cells through two distinct mechanisms. PLoS One 7: e52572.

58. Wenzel U, Nickel A, Daniel H (2005) Melatonin potentiates flavone-induced apoptosis in human colon cancer cells by increasing the level of glycolytic end products. Int J Cancer 116: 236-242.

59. García-Santos G, Antolín I, Herrera F, Martín V, Rodriguez-Blanco J, et al (2006) Melatonin induces apoptosis in human neuroblastoma cancer cells. J Pineal Res 41: 130-135.

60. Laothong U, Hiraku Y, Oikawa S, Intuyod K, Murata M, et al. (2015) Melatonin induces apoptosis in cholangiocarcinoma cell lines by activating the reactive oxygen species-mediated mitochondrial pathway. Oncol Rep 33: 1443-1449.

61. Park EJ, Woo SM, Min KJ, Kwon TK (2014) Transcriptional and posttranslational regulation of Bim controls apoptosis in melatonin-treated human renal cancer Caki cells. J Pineal Res 56: 97-106.

2. Woo SM, Min KJ, Kwon TK (2015) Melatonin-mediated Bim up-regulation and cyclooxygenase-2 (COX-2) down-regulation enhances tunicamycin-induced apoptosis in MDA-MB-231 cells. J Pineal Res 58: 310-320.

63. Wei JY, Li WM, Zhou LL, Lu QN, He W (2015) Melatonin induces apoptosis of colorectal cancer cells through HDAC4 nuclear import mediated by CaMKII inactivation. J Pineal Res 58: 429-438.

64. Fan C, Pan Y, Yang Y, Di S, Jiang S, et al. (2015) HDAC1 inhibition by melatonin leads to suppression of lung adenocarcinoma cells via induction of oxidative stress and activation of apoptotic pathways. J Pineal Res 59: 321-333.

65. Jung-Hynes B, Schmit TL, Reagan-Shaw SR, Siddiqui IA, Mukhtar H, et al. (2011) Melatonin, a novel Sirt1 inhibitor, imparts antiproliferative effects agains prostate cancer in vitro in culture and in vivo in TRAMP model. J Pineal Res 50: $140-149$

66. Cucina A, Proietti S, D'Anselmi F, Coluccia P, Dinicola S, et al. (2009) Evidence for a biphasic apoptotic pathway induced by melatonin in MCF-7 breast cancer cells. J Pineal Res 46: 172-180.

67. Cos S, Mediavilla MD, Fernandez R, Gonzalez-Lamuno D, Sanchez-Barcelo EJ (2002) Does melatonin induce apoptosis in MCF-7 human breast cancer cells in vitro? J Pineal Res 32: 90-96.

68. Weinreb O, Mandel S, Youdim MB (2003) Gene and protein expression profiles of anti- and pro-apoptotic actions of dopamine, R-apomorphine, green tea polyphenol (-)-epigallocatechine-3-gallate, and melatonin. Ann N Y Acad Sci 993: 351-361 
Citation: Cardinali D, Escames G, Acuña-Castroviejo D, Ortiz F, Fernández-Gil B, et al. (2016) Melatonin-Induced Oncostasis, Mechanisms and Clinical Relevance. J Integr Oncol S1: 006. doi:10.4172/2329-6771.S1-006

Page 20 of 25

69. Sainz RM, Mayo JC, Rodriguez C, Tan DX, Lopez-Burillo S, et al. (2003) Melatonin and cell death: differential actions on apoptosis in normal and cance cells. Cell Mol Life Sci 60: 1407-1426.

70. Srivastava S, Lundqvist A, Childs RW (2008) Natural killer cell immunotherapy for cancer: a new hope. Cytotherapy 10: 775-783.

71. Sutlu T, Alici E (2009) Natural killer cell-based immunotherapy in cancer: current insights and future prospects. J Intern Med 266: 154-181.

72. Cheng M, Zhang J, Jiang W, Chen Y, Tian Z (2012) Natural killer cell lines in tumor immunotherapy. Front Med 6: 56-66.

73. Saez MC, Barriga C, Garcia JJ, Rodriguez AB, Masot J, et al. (2005) Melatonin increases the survival time of animals with untreated mammary tumours: neuroendocrine stabilization. Mol Cell Biochem 278: 15-20.

74. Genovese T, Mazzon E, Muià C, Bramanti P, De Sarro A, et al. (2005) Attenuation in the evolution of experimental spinal cord trauma by treatment with melatonin. J Pineal Res 38: 198-208.

75. Poon AM, Liu ZM, Pang CS, Brown GM, Pang SF (1994) Evidence for a direct action of melatonin on the immune system. Biol Signals 3: 107-117.

76. Christopher FL, Dussault I, Miller SC (1991) Population dynamics of natura killer cells in the spleen and bone marrow of normal and leukemic mice during in vivo exposure to interleukin-2. Immunobiology 184: 37-52.

77. Lissoni P, Barni S, Tancini G, Rovelli F, Ardizzoia A, et al. (1993) A study of the mechanisms involved in the immunostimulatory action of the pineal hormone in cancer patients. Oncology 50: 399-402.

78. García-Mauriño S, Pozo D, Carrillo-Vico A, Calvo JR, Guerrero JM (1999) Melatonin activates Th1 lymphocytes by increasing IL-12 production. Life Sci 65: 2143-2150.

79. Regelson W, Pierpaoli W (1987) Melatonin: a rediscovered antitumor hormone? Its relation to surface receptors; sex steroid metabolism, immunologic response, and chronobiologic factors in tumor growth and therapy. Cancer Invest 5: 379385.

80. Liu H, Xu L, Wei JE, Xie MR, Wang SE, et al. (2011) Role of CD4+ CD25+ regulatory $T$ cells in melatonin-mediated inhibition of murine gastric cancer cell growth in vivo and in vitro. Anat Rec (Hoboken) 294: 781-788.

81. Vijayalaxmi, Thomas CR Jr, Reiter RJ, Herman TS (2002) Melatonin: from basic research to cancer treatment clinics. J Clin Oncol 20: 2575-2601.

82. Lardone PJ, Carrillo-Vico A, Molinero P, Rubio A, Guerrero JM (2009) A novel interplay between membrane and nuclear melatonin receptors in human lymphocytes: significance in IL-2 production. Cell Mol Life Sci 66: 516-525.

83. Warburg O, Posener P, Negelein E (1924) Ueber den Stoffwechsel der Tumoren. Biochemische Zeitschrift 152: 319-344.

84. Hevia D, Gonzalez-Menendez P, Quiros-Gonzalez I, Miar A, Rodriguez-Garcia A, et al. (2015) Melatonin uptake through glucose transporters: a new target for melatonin inhibition of cancer. J Pineal Res 58: 234-250.

85. Sauer LA, Dauchy RT (1992) Uptake of plasma lipids by tissue-isolated hepatomas 7288CTC and 7777 in vivo. Br J Cancer 66: 290-296.

86. Hsi LC, Wilson LC, Eling TE (2002) Opposing effects of 15-lipoxygenase-1 and -2 metabolites on MAPK signaling in prostate. Alteration in peroxisome proliferator-activated receptor gamma. J Biol Chem 277: 40549-40556.

87. Blask DE, Sauer LA, Dauchy RT, Holowachuk EW, Ruhoff MS, et al. (1999) Melatonin inhibition of cancer growth in vivo involves suppression of tumor fatty acid metabolism via melatonin receptor-mediated signal transduction events. Cancer Res 59: 4693-4701.

88. Blask DE, Dauchy RT, Sauer LA, Krause JA (2004) Melatonin uptake and growth prevention in rat hepatoma $7288 \mathrm{CTC}$ in response to dietary melatonin: melatonin receptor-mediated inhibition of tumor linoleic acid metabolism to the growth signaling molecule 13-hydroxyoctadecadienoic acid and the potential role of phytomelatonin. Carcinogenesis 25: 951-960.

89. Blask DE, Brainard GC, Dauchy RT, Hanifin JP, Davidson LK, et al. (2005) Melatonin-depleted blood from premenopausal women exposed to light at night stimulates growth of human breast cancer xenografts in nude rats. Cancer Res 65: 11174-11184.

90. Blask DE, Hill SM, Orstead KM, Massa JS (1986) Inhibitory effects of the pineal hormone melatonin and underfeeding during the promotional phase of
7,12-dimethylbenzanthracene-(DMBA)-induced mammary tumorigenesis. J Neural Transm 67: 125-138.

91. Hill SM, Blask DE (1988) Effects of the pineal hormone melatonin on the proliferation and morphological characteristics of human breast cancer cells (MCF-7) in culture. Cancer Res 48: 6121-6126.

92. Blask DE, Dauchy RT, Dauchy EM, Mao L, Hill SM, et al. (2014) Light exposure at night disrupts host/cancer circadian regulatory dynamics: impact on the Warburg effect, lipid signaling and tumor growth prevention. PLoS One 9 : e102776.

93. Hanahan D, Weinberg RA (2011) Hallmarks of cancer: the next generation Cell 144: 646-674.

94. Feng L, Tao L, Dawei H, Xuliang L, Xiaodong L (2013) HIF-1alpha Expression Correlates with Cellular Apoptosis, Angiogenesis and Clinical Prognosis in Rectal Carcinoma. Pathol Oncol Res 20: 603-610.

95. Tischer E, Mitchell R, Hartman T, Silva M, Gospodarowicz D, et al. (1991) The human gene for vascular endothelial growth factor. Multiple protein forms are encoded through alternative exon splicing. J Biol Chem 266: 11947-11954.

96. Alvarez-García V, González A, Alonso-González C, Martínez-Campa C, Cos S (2013) Regulation of vascular endothelial growth factor by melatonin in human breast cancer cells. J Pineal Res 54: 373-380.

97. Carbajo-Pescador S, Ordonez R, Benet M, Jover R, Garcia-Palomo A, et al. (2013) Inhibition of VEGF expression through blockade of Hif1alpha and STAT3 signalling mediates the anti-angiogenic effect of melatonin in HepG2 liver cancer cells. Br J Cancer 109: 83-91.

98. Park SY, Jang WJ, Yi EY, Jang JY, Jung Y, et al. (2010) Melatonin suppresses tumor angiogenesis by inhibiting HIF-1alpha stabilization under hypoxia. J Pineal Res 48: 178-184.

99. Landskroner-Eiger S, Moneke I, Sessa WC (2013) miRNAs as modulators of angiogenesis. Cold Spring Harb Perspect Med 3: a006643.

100.Sohn EJ, Won G, Lee J, Lee S, Kim SH (2015) Upregulation of miRNA3195 and miRNA374b Mediates the Anti-Angiogenic Properties of Melatonin in Hypoxic PC-3 Prostate Cancer Cells. J Cancer 6: 19-28.

101. Knowles JP, Shi-Wen X, Haque SU, Bhalla A, Dashwood MR, et al. (2012) Endothelin-1 stimulates colon cancer adjacent fibroblasts. Int J Cancer 130: 1264-1272.

102. Cui P, Luo Z, Zhang H, Su Y, Li A, et al. (2006) Effect and mechanism of melatonin's action on the proliferation of human umbilical vein endothelial cells. J Pineal Res 41: 358-362.

103.León J, Casado J, Jiménez Ruiz SM, Zurita MS, González-Puga C, et al (2014) Melatonin reduces endothelin-1 expression and secretion in colon cancer cells through the inactivation of FoxO-1 and NF- $\mathrm{k} \beta$. J Pineal Res 56 415-426.

104. Jardim-Perassi BV, Arbab AS, Ferreira LC, Borin TF, Varma NR, et al. (2014) Effect of melatonin on tumor growth and angiogenesis in xenograft model of breast cancer. PLoS One 9: e85311.

105. Wu XR (2005) Urothelial tumorigenesis: a tale of divergent pathways. Nat Rev Cancer 5: 713-725.

106. Mao L, Yuan L, Slakey LM, Jones FE, Burow ME, et al. (2010) Inhibition of breast cancer cell invasion by melatonin is mediated through regulation of the p38 mitogen-activated protein kinase signaling pathway. Breast Cancer Res 12: R107.

107. Rudra DS, Pal U, Maiti NC, Reiter RJ, Swarnakar S (2013) Melatonin inhibits matrix metalloproteinase- 9 activity by binding to its active site. J Pineal Res 54: 398-405.

108. Soto-Vega E, Meza I, Ramírez-Rodríguez G, Benitez-King G (2004) Melatonin stimulates calmodulin phosphorylation by protein kinase C. J Pineal Res 37 : 98-106.

109. Jechlinger M, Grunert S, Tamir IH, Janda E, Lüdemann S, et al. (2003) Expression profiling of epithelial plasticity in tumor progression. Oncogene 22 7155-7169.

110. Ten Berge D, Koole W, Fuerer C, Fish M, Eroglu E, et al. (2008) Wnt signaling mediates self-organization and axis formation in embryoid bodies. Cell Stem Cell 3: 508-518.

111. Yan D, Avtanski D, Saxena NK, Sharma D (2012) Leptin-induced epithelial- 
Citation: Cardinali D, Escames G, Acuña-Castroviejo D, Ortiz F, Fernández-Gil B, et al. (2016) Melatonin-Induced Oncostasis, Mechanisms and Clinical Relevance. J Integr Oncol S1: 006. doi:10.4172/2329-6771.S1-006

Page 21 of 25

mesenchymal transition in breast cancer cells requires beta-catenin activation via Akt/ GSK3- and MTA1/Wnt1 protein-dependent pathways. J Biol Chem 287: 8598-8612.

112. Mao L, Dauchy RT, Blask DE, Slakey LM, Xiang S, et al. (2012) Circadian gating of epithelial-to-mesenchymal transition in breast cancer cells via melatonin-regulation of GSK3beta. Mol Endocrinol 26: 1808-1820.

113. Mao L, Dauchy RT, Blask DE, Dauchy EM, Slakey LM, et al. (2016) Melatonin suppression of aerobic glycolysis (Warburg effect), survival signalling and metastasis in human leiomyosarcoma. J Pineal Res 60: 167-177.

114. Sandes EO, Faletti AG, Riveros MD, Vidal MC, Gimenez L, et al. (2005) Expression of inducible nitric oxide synthase in tumoral and non-tumoral epithelia from bladder cancer patients. Nitric Oxide 12: 39-45.

115. Sandes EO, Lodillinsky C, Langle Y, Belgorosky D, Marino L, et al. (2012) Inducible nitric oxide synthase and PPARgamma are involved in bladder cancer progression. J Urol 188: 967-973.

116. Hickok JR, Thomas DD (2010) Nitric oxide and cancer therapy: the emperor has NO clothes. Curr Pharm Des 16: 381-391.

117. Belgorosky D, Langle Y, Prack Mc Cormick B, Colombo L, Sandes E, et al (2014) Inhibition of nitric oxide is a good therapeutic target for bladder tumors that express iNOS. Nitric Oxide 36: 11-18.

118. Crespo E, Macias M, Pozo D, Escames G, Martin M, et al. (1999) Melatonin inhibits expression of the inducible NO synthase II in liver and lung and prevents endotoxemia in lipopolysaccharide-induced multiple organ dysfunction syndrome in rats. FASEB J 13: 1537-1546.

119. Escames G, Leon J, Macias M, Khaldy H, Acuna-Castroviejo D (2003) Melatonin counteracts lipopolysaccharide-induced expression and activity of mitochondrial nitric oxide synthase in rats. FASEB J 17: 932-934

120. Ortiz GG, Pacheco-Moises FP, Gomez-Rodriguez VM, Gonzalez-Renovato ED, Torres-Sanchez ED, et al. (2013) Fish oil, melatonin and vitamin E attenuates midbrain cyclooxygenase-2 activity and oxidative stress after the administration of 1-methyl-4-phenyl- 1,2,3,6- tetrahydropyridine. Metab Brain Dis 28: 705-709.

121.Poliandri AH, Esquifino Al, Cano $P$, Jiménez V, Lafuente A, et al. (2006) In vivo protective effect of melatonin on cadmium-induced changes in redox balance and gene expression in rat hypothalamus and anterior pituitary. $J$ Pineal Res 41: 238-246.

122. Kiefer T, Ram PT, Yuan L, Hill SM (2002) Melatonin inhibits estrogen receptor transactivation and cAMP levels in breast cancer cells. Breast Cancer Res Treat 71: 37-45

123. Ram PT, Dai J, Yuan L, Dong C, Kiefer TL, et al. (2002) Involvement of the mt1 melatonin receptor in human breast cancer. Cancer Lett 179: 141-150.

124. Cos S, Gonzalez A, Martinez-Campa C, Mediavilla MD, Alonso-Gonzalez C et al. (2006) Estrogen-signaling pathway: a link between breast cancer and melatonin oncostatic actions. Cancer Detect Prev 30: 118-128.

125. Cos S, Sánchez-Barceló EJ (2000) Melatonin and mammary pathologica growth. Front Neuroendocrinol 21: 133-170.

126. Cos S, Sánchez-Barceló EJ (2000) Melatonin, experimental basis for possible application in breast cancer prevention and treatment. Histol Histopathol 15: 637-647.

127. Cos S, Blask DE (1994) Melatonin modulates growth factor activity in MCF-7 human breast cancer cells. J Pineal Res 17: 25-32.

128. Rato AG, Pedrero JG, Martinez MA, del Rio B, Lazo PS, et al. (1999) Melatonin blocks the activation of estrogen receptor for DNA binding. FASEB J 13: 857 868.

129. Simpson E, Rubin G, Clyne C, Robertson K, O’Donnell L, et al. (1999) Local estrogen biosynthesis in males and females. Endocr Relat Cancer 6: 131-137.

130.Sánchez-Barceló EJ, Cos S, Fernández R, Mediavilla MD (2003) Melatonin and mammary cancer: a short review. Endocr Relat Cancer 10: 153-159.

131.Sánchez-Barceló EJ, Cos S, Mediavilla D, Martínez-Campa C, González A et al. (2005) Melatonin-estrogen interactions in breast cancer. J Pineal Res 38: $217-222$.

132. Cos S, Martínez-Campa C, Mediavilla MD, Sánchez-Barceló EJ (2005) Melatonin modulates aromatase activity in MCF-7 human breast cancer cells. J Pineal Res 38: 136-142.
133. Gonzalez A, Martinez-Campa C Mediavilla MD, Alonso-Gonzalez C Sanchez Mateos S, et al. (2007) Effects of MT1 melatonin receptor overexpression on the aromatase-suppressive effect of melatonin in MCF-7 human breast cancer cells. Oncol Rep 17: 947-953.

134. Bodnar AG, Ouellette M, Frolkis M, Holt SE, Chiu CP, et al. (1998) Extension of life-span by introduction of telomerase into normal human cells. Science 279: 349-352.

135. Akbulut KG, Gonul B, Akbulut H (2009) The role of melatonin on gastric mucosal cell proliferation and telomerase activity in ageing. J Pineal Res 47 308-312.

136. Leon-Blanco MM, Guerrero JM, Reiter RJ, Calvo JR, Pozo D (2003) Melatonin inhibits telomerase activity in the MCF-7 tumor cell line both in vivo and in vitro. J Pineal Res 35: 204-211.

137. Leon-Blanco MM, Guerrero JM, Reiter RJ, Pozo D (2004) RNA expression of human telomerase subunits TR and TERT is differentially affected by melatonin receptor agonists in the MCF-7 tumor cell line. Cancer Lett 216 : 73-80.

138. Galano A, Tan DX, Reiter RJ (2011) Melatonin as a natural ally against oxidative stress: a physicochemical examination. J Pineal Res 51: 1-16

139. Costa A, Scholer-Dahirel A, Mechta-Grigoriou F (2014) The role of reactive oxygen species and metabolism on cancer cells and their microenvironment. Semin Cancer Biol 25:23-32.

140. Valko M, Rhodes CJ, Moncol J, Izakovic M, Mazur M (2006) Free radicals, metals and antioxidants in oxidative stress-induced cancer. Chem Biol Interact 160: $1-40$.

141. Laothong U, Pinlaor P, Boonsiri P, Pairojkul C, Priprem A, et al. (2013) Melatonin inhibits cholangiocarcinoma and reduces liver injury in Opisthorchis viverrini-infected and N-nitrosodimethylamine-treated hamsters. J Pineal Res 55: 257-266.

142. López LC, Escames G, Ortiz F, Ros E, Acuña-Castroviejo D (2006) Melatonin restores the mitochondrial production of ATP in septic mice. Neuro Endocrino Lett 27: 623-630.

143. Escames G, López LC, Ortiz F, López A, García JA, et al. (2007) Attenuation of cardiac mitochondrial dysfunction by melatonin in septic mice. FEBS J 274 2135-2147.

144. Galano A, Tan DX, Reiter RJ (2013) On the free radical scavenging activities of melatonin's metabolites, AFMK and AMK. J Pineal Res 54: 245-257.

145. Antolin I, Rodriguez C, Sainz RM, Mayo JC, Uria H, et al. (1996) Neurohormone melatonin prevents cell damage: effect on gene expression for antioxidant enzymes. FASEB J 10: 882-890.

146. Acuña Castroviejo D, López LC, Escames G, López A, García JA, et al. (2011) Melatonin-mitochondria interplay in health and disease. Curr Top Med Chem 11: $221-240$.

147. Jou MJ, Peng TI, Hsu LF, Jou SB, Reiter RJ, et al. (2010) Visualization of melatonin's multiple mitochondrial levels of protection against mitochondrial $\mathrm{Ca}(2+)$-mediated permeability transition and beyond in rat brain astrocytes. $J$ Pineal Res 48: 20-38.

148. Lopez A, Garcia JA, Escames G, Venegas C, Ortiz F, et al. (2009) Melatonin protects the mitochondria from oxidative damage reducing oxygen consumption, membrane potential, and superoxide anion production. J Pineal Res 46: 188-198.

149.Paradies G, Petrosillo G, Paradies V, Reiter RJ, Ruggiero FM (2010) Melatonin, cardiolipin and mitochondrial bioenergetics in health and disease. J Pineal Res 48: 297-310.

150. Martin M, Macias M, Escames G, Leon J, Acuna-Castroviejo D (2000) Melatonin but not vitamins $\mathrm{C}$ and $\mathrm{E}$ maintains glutathione homeostasis in t-butyl hydroperoxide-induced mitochondrial oxidative stress. FASEB J 14 1677-1679.

151. Martin V, Sainz RM, Antolin I, Mayo JC, Herrera F, et al. (2002) Severa antioxidant pathways are involved in astrocyte protection by melatonin. J Pineal Res 33: 204-212.

152. Marnett LJ, Riggins JN, West JD (2003) Endogenous generation of reactive oxidants and electrophiles and their reactions with DNA and protein. $J$ Clin Invest 111: 583-593.

153. Tan DX, Poeggeler B, Reiter RJ, Chen LD, Chen S, et al. (1993) The pineal 
Citation: Cardinali D, Escames G, Acuña-Castroviejo D, Ortiz F, Fernández-Gil B, et al. (2016) Melatonin-Induced Oncostasis, Mechanisms and Clinical Relevance. J Integr Oncol S1: 006. doi:10.4172/2329-6771.S1-006

Page 22 of 25

hormone melatonin inhibits DNA-adduct formation induced by the chemical carcinogen safrole in vivo. Cancer Lett 70: 65-71.

154. Tan DX, Manchester LC, Reiter RJ, Plummer BF, Hardies LJ, et al. (1998) A novel melatonin metabolite, cyclic 3-hydroxymelatonin: a biomarker of in vivo hydroxyl radical generation. Biochem Biophys Res Commun 253: 614-620.

155. Tan DX, Manchester LC, Burkhardt S, Sainz RM, Mayo JC, et al. (2001) N1acetyl-N2-formyl-5-methoxykynuramine, a biogenic amine and melatonin metabolite, functions as a potent antioxidant. FASEB J 15: 2294-2296.

156. Tan DX, Manchester LC, Helton P, Reiter RJ (2007) Phytoremediative capacity of plants enriched with melatonin. Plant Signal Behav 2: 514-516.

157. Gilad E, Wong HR, Zingarelli B, Virag L, O'Connor M, et al. (1998) Melatonin inhibits expression of the inducible isoform of nitric oxide synthase in murine macrophages: role of inhibition of NFkappaB activation. FASEB J 12: 685-693.

158. Wang J, Hao H, Yao L, Zhang X, Zhao S, et al. (2012) Melatonin suppresses migration and invasion via inhibition of oxidative stress pathway in glioma cells. J Pineal Res 53: 180-187.

159. Chinery R, Brockman JA, Peeler MO, Shyr Y, Beauchamp RD, et al. (1997) Antioxidants enhance the cytotoxicity of chemotherapeutic agents in colorectal cancer: a p53-independent induction of p21WAF1/CIP1 via C/EBPbeta. Nat Med 3: 1233-1241.

160. Stevens RG (1987) Electric power use and breast cancer: a hypothesis. Am J Epidemiol 125: 556-561.

161. Stevens RG, Zhu Y (2015) Electric light, particularly at night, disrupts human circadian rhythmicity: is that a problem? Philos Trans $\mathrm{R}$ Soc Lond B Biol Sci.

162. Hill SM, Blask DE, Xiang S, Yuan L, Mao L, et al. (2011) Melatonin and associated signaling pathways that control normal breast epithelium and breast cancer. J Mammary Gland Biol Neoplasia 16: 235-245.

163. Wu UI, Mai FD, Sheu JN, Chen LY, Liu YT, et al. (2011) Melatonin inhibits microglial activation, reduces pro-inflammatory cytokine levels, and rescues hippocampal neurons of adult rats with acute Klebsiella pneumoniae meningitis. J Pineal Res 50: 159-170.

164. Wood PA, Yang X, Hrushesky WJ (2009) Clock genes and cancer. Integr Cancer Ther 8: 303-308.

165. deHaro D, Kines KJ, Sokolowski M, Dauchy RT, Streva VA, et al. (2014) Regulation of L1 expression and retrotransposition by melatonin and its receptor: implications for cancer risk associated with light exposure at night Nucleic Acids Res 42: 7694-7707.

166. Han Y, DeMorrow S, Invernizzi P, Jing Q, Glaser S, et al. (2011) Melatonin exerts by an autocrine loop antiproliferative effects in cholangiocarcinoma: its synthesis is reduced favoring cholangiocarcinoma growth. Am J Physiol Gastrointest Liver Physiol 301: G623-G633.

167. Reiter RJ, Tan DX, Sainz RM, Mayo JC, Lopez-Burillo S (2002) Melatonin: reducing the toxicity and increasing the efficacy of drugs. J Pharm Pharmacol 54: $1299-1321$.

168. Ortiz F, Acuña-Castroviejo D, Doerrier C, Dayoub JC, López LC, et al. (2015) Melatonin blunts the mitochondrial/NLRP3 connection and protects against radiation-induced oral mucositis. J Pineal Res 58: 34-49.

169. Howell D, Oliver TK, Keller-Olaman S, Davidson JR, Garland S, et al. (2014) Sleep disturbance in adults with cancer: a systematic review of evidence for best practices in assessment and management for clinical practice. Ann Oncol 25: 791-800.

170.Dahiya S, Ahluwalia MS, Walia HK (2013) Sleep disturbances in cancer patients: underrecognized and undertreated. Cleve Clin J Med 80: 722-732.

171. Chen WY, Giobbie-Hurder A, Gantman K, Savoie J, Scheib R, et al. (2014) A randomized, placebo-controlled trial of melatonin on breast cancer survivors impact on sleep, mood, and hot flashes. Breast Cancer Res Treat 145: 381 388.

172. Dickerson SS, Connors LM, Fayad A, Dean GE (2014) Sleep-wake disturbances in cancer patients: narrative review of literature focusing on improving quality of life outcomes. Nat Sci Sleep 6: 85-100.

173. Harris B, Ross J, Sanchez-Reilly S (2014) Sleeping in the arms of cancer: a review of sleeping disorders among patients with cancer. Cancer J 20: 299305.

174.Davidson JR, MacLean AW, Brundage MD, Schulze K (2002) Sleep disturbance in cancer patients. Soc Sci Med 54: 1309-1321.
175. Otte JL, Carpenter JS, Manchanda S, Rand KL, Skaar TC, et al. (2015) Systematic review of sleep disorders in cancer patients: can the prevalence of sleep disorders be ascertained? Cancer Med 4: 183-200.

176. Davis MP, Goforth HW (2014) Long-term and short-term effects of insomnia in cancer and effective interventions. Cancer J 20: 330-344.

177. Irwin MR (2015) Why sleep is important for health: a psychoneuroimmunology perspective. Annu Rev Psychol 66: 143-172.

178. Casault L, Savard J, Ivers H, Savard MH, Simard S (2012) Utilization of hypnotic medication in the context of cancer: predictors and frequency of use. Support Care Cancer 20: 1203-1210

179. Thekdi SM, Trinidad A, Roth A (2015) Psychopharmacology in cancer. Curr Psychiatry Rep 17: 529.

180. Cardinali DP, Srinivasan V, Brzezinski A, Brown GM (2012) Melatonin and its analogs in insomnia and depression. J Pineal Res 52: 365-375.

181. Cardinali DP, Golombek DA, Rosenstein RE, Brusco LI, Vigo DE (2015) Assessing the efficacy of melatonin to curtail benzodiazepine/Z drug abuse. Pharmacol Res.

182. Brzezinski A, Vangel MG, Wurtman RJ, Norrie G, Zhdanova I, et al. (2005) Effects of exogenous melatonin on sleep: a meta-analysis. Sleep Med Rev 9: 41-50.

183. Ferracioli-Oda E, Qawasmi A, Bloch MH (2013) Meta-analysis: melatonin for the treatment of primary sleep disorders. PLoS One 8: e63773.

184. Buscemi N, Vandermeer B, Hooton N, Pandya R, Tjosvold L, et al. (2006) Efficacy and safety of exogenous melatonin for secondary sleep disorders and sleep disorders accompanying sleep restriction: meta-analysis. BMJ 332: 385-393.

185. Gorfine T, Assaf Y, Goshen-Gottstein Y, Yeshurun Y, Zisapel N (2006) Sleepanticipating effects of melatonin in the human brain. Neuroimage 31: 410-418.

186. Wilson SJ, Nutt DJ, Alford C, Argyropoulos SV, Baldwin DS, et al. (2010) British Association for Psychopharmacology consensus statement on evidence-based treatment of insomnia, parasomnias and circadian rhythm disorders. J Psychopharmacol 24: 1577-1601.

187. Goerling U, Odebrecht S, Schiller G, Schlag PM (2006) [Need for psychosocial care in in-patients with tumour disease. Investigations conducted in a clinic specializing in tumour surgery]. Chirurg 77: 41-46.

188. Carlson LE, Angen M, Cullum J, Goodey E, Koopmans J, et al. (2004) High levels of untreated distress and fatigue in cancer patients. $\mathrm{Br} J$ Cancer 90 2297-2304.

189. Campos Costa I, Nogueira Carvalho H, Fernandes L (2013) Aging, circadian rhythms and depressive disorders: a review. Am J Neurodegener Dis 2: 228246.

190.Pandi-Perumal SR, Trakht I, Spence DW, Srinivasan V, Dagan Y, et al. (2008) The roles of melatonin and light in the pathophysiology and treatment of circadian rhythm sleep disorders. Nat Clin Pract Neurol 4: 436-447.

191.Leibenluft E, Feldman-Naim S, Turner EH, Wehr TA, Rosenthal NE (1997) Effects of exogenous melatonin administration and withdrawal in five patients with rapid-cycling bipolar disorder. J Clin Psychiatry 58: 383-388.

192. Dolberg OT, Hirschmann S, Grunhaus L (1998) Melatonin for the treatment of sleep disturbances in major depressive disorder. Am J Psychiatry 155: 11191121

193. Dalton EJ, Rotondi D, Levitan RD, Kennedy SH, Brown GM (2000) Use of slow-release melatonin in treatment-resistant depression. J Psychiatry Neurosci 25: 48-52.

194. Cardinali DP, Pandi-Perumal SR, Niles LP (2008) Melatonin and its receptors Biological function in circadian sleep-wake regulation. Cambridge University Press, Cambridge UK.

195. Hansen MV, Andersen LT, Madsen MT, Hageman I, Rasmussen LS, et al. (2014) Effect of melatonin on depressive symptoms and anxiety in patients undergoing breast cancer surgery: a randomized, double-blind, placebocontrolled trial. Breast Cancer Res Treat 145: 683-695.

196. Sookprasert A, Johns NP, Phunmanee A, Pongthai P, Cheawchanwattana A, et al. (2014) Melatonin in patients with cancer receiving chemotherapy: a randomized, double-blind, placebo-controlled trial. Anticancer Res 34: 73277337. 
Citation: Cardinali D, Escames G, Acuña-Castroviejo D, Ortiz F, Fernández-Gil B, et al. (2016) Melatonin-Induced Oncostasis, Mechanisms and Clinical Relevance. J Integr Oncol S1: 006. doi:10.4172/2329-6771.S1-006

Page 23 of 25

197. Falkson G, Falkson HC, Steyn ME, Rapoport BL, Meyer BJ (1990) Plasma melatonin in patients with breast cancer. Oncology 47: 401-405.

198. Travis RC, Allen DS, Fentiman IS, Key TJ (2004) Melatonin and breast cancer: a prospective study. J Natl Cancer Inst 96: 475-482.

199. Peplonska B, Bukowska A, Sobala W, Reszka E, Gromadzinska J, et al. (2012) Rotating night shift work and mammographic density. Cancer Epidemiol Biomarkers Prev 21: 1028-1037.

200. Jia Y, Lu Y, Wu K, Lin Q, Shen W, et al. (2013) Does night work increase the risk of breast cancer? A systematic review and meta-analysis of epidemiological studies. Cancer Epidemiol 37: 197-206.

201.Wang F, Yeung KL, Chan WC, Kwok CC, Leung SL, et al. (2013) A metaanalysis on dose-response relationship between night shift work and the risk of breast cancer. Ann Oncol 24: 2724-2732.

202. ljaz S, Verbeek J, Seidler A, Lindbohm ML, Ojajarvi A, et al. (2013) Nightshift work and breast cancer--a systematic review and meta-analysis. Scand J Work Environ Health 39: 431-447.

203. Stevens RG, Hansen J, Costa G, Haus E, Kauppinen T, et al. (2011) Considerations of circadian impact for defining 'shift work' in cancer studies: IARC Working Group Report. Occup Environ Med 68: 154-162.

204. Mills E, Wu P, Seely D, Guyatt G (2005) Melatonin in the treatment of cancer: a systematic review of randomized controlled trials and meta-analysis. J Pineal Res 39: 360-366.

205. Wang YM, Jin BZ, Ai F, Duan CH, Lu YZ, et al. (2012) The efficacy and safety of melatonin in concurrent chemotherapy or radiotherapy for solid tumors: a meta-analysis of randomized controlled trials. Cancer Chemother Pharmaco 69: $1213-1220$

206. Berk L, Berkey B, Rich T, Hrushesky W, Blask D, et al. (2007) Randomized phase II trial of high-dose melatonin and radiation therapy for RPA class 2 patients with brain metastases (RTOG 0119). Int J Radiat Oncol Biol Phys 68: 852-857.

207. Schernhammer ES, Giobbie-Hurder A, Gantman K, Savoie J, Scheib R, et al. (2012) A randomized controlled trial of oral melatonin supplementation and breast cancer biomarkers. Cancer Causes Control 23: 609-616.

208. Del Fabbro E, Dev R, Hui D, Palmer L, Bruera E (2013) Effects of melatonin on appetite and other symptoms in patients with advanced cancer and cachexia: a double-blind placebo-controlled trial. J Clin Oncol 31: 1271-1276.

209. Andersen LP, Werner MU, Rosenkilde MM, Fenger AQ, Petersen MC, et al (2015) Pharmacokinetics of high-dose intravenous melatonin in humans. J Clin Pharmacol.

210. Galley HF, Lowes DA, Allen L, Cameron G, Aucott LS, et al. (2014) Melatonin as a potential therapy for sepsis: a phase I dose escalation study and an ex vivo whole blood model under conditions of sepsis. J Pineal Res 56: 427-438.

211. Weishaupt JH, Bartels C, Pölking E, Dietrich J, Rohde G, et al. (2006) Reduced oxidative damage in ALS by high-dose enteral melatonin treatment. $\mathrm{J}$ Pineal Res 41: 313-323.

212. Chahbouni M, Escames G, Venegas C, Sevilla B, Garcia JA, et al. (2010) Melatonin treatment normalizes plasma pro-inflammatory cytokines and nitrosative/oxidative stress in patients suffering from Duchenne muscular dystrophy. J Pineal Res 48: 282-289.

213. Lieberman HR, Waldhauser F, Garfield G, Lynch HJ, Wurtman RJ (1984) Effects of melatonin on human mood and performance. Brain Res 323: 201207.

214. Voordouw BC, Euser R, Verdonk RE, Alberda BT, de Jong FH, et al. (1992) Melatonin and melatonin-progestin combinations alter pituitary-ovarian function in women and can inhibit ovulation. J Clin Endocrinol Metab 74: 108117.

215. Nickkholgh A, Schneider H, Sobirey M, Venetz WP, Hinz U, et al. (2011) The use of high-dose melatonin in liver resection is safe: first clinical experience. $J$ Pineal Res 50: 381-388.

216.Grant SG, Melan MA, Latimer JJ, Witt-Enderby PA (2009) Melatonin and breast cancer: cellular mechanisms, clinical studies and future perspectives. Expert Rev Mol Med 11: e5.

217. Hansen MV, Madsen MT, Hageman I, Rasmussen LS, Bokmand S, et al. (2012) The effect of MELatOnin on Depression, anxietY, cognitive function and sleep disturbances in patients with breast cancer. The MELODY trial: protocol for a randomised, placebo-controlled, double-blinded trial. BMJ Open 2: e000647.

218. Tamarkin L, Danforth D, Lichter A, DeMoss E, Cohen M, et al. (1982) Decreased nocturnal plasma melatonin peak in patients with estrogen receptor positive breast cancer. Science 216: 1003-1005.

219. Danforth DN Jr, Tamarkin L, Mulvihill JJ, Bagley CS, Lippman ME (1985) Plasma melatonin and the hormone-dependency of human breast cancer. $J$ Clin Oncol 3: 941-948.

220. Lissoni P, Tancini G, Barni S, Crispino S, Paolorossi F, et al. (1988) Melatonin increase as predictor for tumor objective response to chemotherapy in advanced cancer patients. Tumori 74: 339-345.

221. Bartsch C, Bartsch H, Fuchs U, Lippert TH, Bellmann O, et al. (1989) Stagedependent depression of melatonin in patients with primary breast cancer Correlation with prolactin, thyroid stimulating hormone, and steroid receptors. Cancer 64: 426-433.

222. Skene DJ, Bojkowski CJ, Currie JE, Wright J, Boulter PS et al. (1990) 6-sulphatoxymelatonin production in breast cancer patients. J Pineal Res 8: 269-276.

223. Bartsch C, Bartsch H, Bellmann O, Lippert TH (1991) Depression of serum melatonin in patients with primary breast cancer is not due to an increased peripheral metabolism. Cancer 67: 1681-1684.

224. Bartsch C, Bartsch H, Schmidt A, llg S, Bichler KH, et al. (1992) Melatonin and 6 -sulfatoxymelatonin circadian rhythms in serum and urine of primary prostate cancer patients: evidence for reduced pineal activity and relevance of urinary determinations. Clin Chim Acta 209: 153-167.

225. Grin W, Grunberger W (1998) A significant correlation between melatonin deficiency and endometrial cancer. Gynecol Obstet Invest 45: 62-65.

226. Mazzoccoli G, Carughi S, De CA, La VM, Giuliani A, et al. (2003) Neuroendocrine alterations in lung cancer patients. Neuro Endocrinol Lett 24: 77-82.

227. Schernhammer ES, Hankinson SE (2005) Urinary melatonin levels and breast cancer risk. J Natl Cancer Inst 97: 1084-1087.

228. Schernhammer ES, Berrino F, Krogh V, Secreto G, Micheli A, et al (2008) Urinary 6-sulfatoxymelatonin levels and risk of breast cancer in postmenopausal women. J Natl Cancer Inst 100: 898-905.

229. Wu AH, Wang R, Koh WP, Stanczyk FZ, Lee HP, et al. (2008) Sleep duration, melatonin and breast cancer among Chinese women in Singapore. Carcinogenesis 29: 1244-1248.

230. Schernhammer ES, Berrino F, Krogh V, Secreto G, Micheli A, et al. (2010) Urinary 6-Sulphatoxymelatonin levels and risk of breast cancer in premenopausal women: the ORDET cohort. Cancer Epidemiol Biomarkers Prev 19: 729-737.

231.Peplonska B, Bukowska A, Gromadzinska J, Sobala W, Reszka E, et al. (2012) Night shift work characteristics and 6-sulfatoxymelatonin (MT6s) in rotating night shift nurses and midwives. Occup Environ Med 69: 339-346.

232. Wang XS, Tipper S, Appleby PN, Allen NE, Key TJ, et al. (2014) First-Morning Urinary Melatonin and Breast Cancer Risk in the Guernsey Study. Am J Epidemiol 179: 584-593.

233. Lissoni P, Brivio F, Barni S, Tancini G, Cattaneo G, et al. (1990) Neuroimmunotherapy of human cancer with interleukin-2 and the neurohormone melatonin: its efficacy in preventing hypotension. Anticancer Res 10: 1759-1761.

234. Lissoni P, Barni S, Cattaneo G, Tancini G, Esposti G, et al. (1991) Clinica results with the pineal hormone melatonin in advanced cancer resistant to standard antitumor therapies. Oncology 48: 448-450.

235. Gonzalez R, Sanchez A, Ferguson JA, Balmer C, Daniel C, et al. (1991) Melatonin therapy of advanced human malignant melanoma. Melanoma Res 1: $237-243$

236. Lissoni P, Barni S, Ardizzoia A, Paolorossi F, Crispino S, et al. (1992) Randomized study with the pineal hormone melatonin versus supportive care alone in advanced nonsmall cell lung cancer resistant to a first-line chemotherapy containing cisplatin. Oncology 49: 336-339.

237. Lissoni P, Tisi E, Barni S, Ardizzoia A, Rovelli F, et al. (1992) Biological and clinical results of a neuroimmunotherapy with interleukin-2 and the pineal 
hormone melatonin as a first line treatment in advanced non-small cell lung cancer. Br J Cancer 66: 155-158

238. Lissoni P, Barni S, Ardizzoia A, Brivio F, Tancini G, et al. (1992) Immunological effects of a single evening subcutaneous injection of low-dose interleukin-2 in association with the pineal hormone melatonin in advanced cancer patients. $J$ Biol Regul Homeost Agents 6: 132-136.

239. Lissoni P, Barni S, Tancini G, Ardizzoia A, Rovelli F, et al. (1993) Immunotherapy with subcutaneous low-dose interleukin-2 and the pineal indole melatonin as a new effective therapy in advanced cancers of the digestive tract. $\mathrm{Br} \mathrm{J}$ Cancer 67: 1404-1407.

240. Lissoni P, Barni S, Ardizzoia A, Olivini G, Brivio F, et al. (1993) Cancer immunotherapy with low-dose interleukin-2 subcutaneous administration potential efficacy in most solid tumor histotypes by a concomitant treatment with the pineal hormone melatonin. J Biol Regul Homeost Agents 7: 121-125.

241. Aldeghi R, Lissoni P, Barni S, Ardizzoia A, Tancini G, et al. (1994) Low-dose interleukin-2 subcutaneous immunotherapy in association with the pineal hormone melatonin as a first-line therapy in locally advanced or metastatic hepatocellular carcinoma. Eur J Cancer 30: 167-170.

242. Lissoni P, Barni S, Ardizzoia A, Tancini G, Conti A, et al. (1994) A randomized study with the pineal hormone melatonin versus supportive care alone in patients with brain metastases due to solid neoplasms. Cancer 73: 699-701.

243. Neri B, Fiorelli C, Moroni F, Nicita G, Paoletti MC, et al. (1994) Modulation of human lymphoblastoid interferon activity by melatonin in metastatic renal cell carcinoma. A phase II study. Cancer 73: 3015-3019.

244. Brackowski R, Zubelewicz B, Romanowski W, Lissoni P, Barni S, et al. (1994) Preliminary study on modulation of the biological effects of tumor necrosis factor-alpha in advanced cancer patients by the pineal hormone melatonin. $J$ Biol Regul Homeost Agents 8: 77-80.

245. Lissoni P, Meregalli S, Fossati V, Paolorossi F, Barni S, et al. (1994) A randomized study of immunotherapy with low-dose subcutaneous interleukin-2 plus melatonin vs chemotherapy with cisplatin and etoposide as first-line therapy for advanced non-small cell lung cancer. Tumori 80: 464-467.

246. Lissoni P, Brivio F, Brivio O, Fumagalli L, Gramazio F, et al. (1995) Immune effects of preoperative immunotherapy with high-dose subcutaneous interleukin-2 versus neuroimmunotherapy with low-dose interleukin-2 plus the neurohormone melatonin in gastrointestinal tract tumor patients. J Biol Regul Homeost Agents 9: 31-33.

247. Lissoni P, Barni S, Tancini G, Mainini E, Piglia F, et al. (1995) Immunoendocrine therapy with low-dose subcutaneous interleukin-2 plus melatonin of locally advanced or metastatic endocrine tumors. Oncology 52: 163-166.

248. Lissoni P, Barni S, Brivio F, Rossini F, Fumagalli L, et al. (1995) Treatment of cancer-related thrombocytopenia by low-dose subcutaneous interleukin-2 plus the pineal hormone melatonin: a biological phase II study. J Biol Regul Homeost Agents 9: 52-54.

249. Lissoni P, Ardizzoia A, Barni S, Brivio F, Tisi E, et al. (1995) Efficacy and tolerability of cancer neuroimmunotherapy with subcutaneous low-dose interleukin-2 and the pineal hormone melatonin - a progress report of 200 patients with advanced solid neoplasms. Oncol Rep 2: 1063-1068.

250.Barni S, Lissoni P, Cazzaniga M, Ardizzoia A, Meregalli S, et al. (1995) A randomized study of low-dose subcutaneous interleukin-2 plus melatonin versus supportive care alone in metastatic colorectal cancer patients progressing under 5-fluorouracil and folates. Oncology 52: 243-245.

251. Lissoni P, Meregalli S, Nosetto L, Barni S, Tancini G, et al. (1996) Increased survival time in brain glioblastomas by a radioneuroendocrine strategy with radiotherapy plus melatonin compared to radiotherapy alone. Oncology 53 : 43-46.

252. Lissoni P, Pittalis S, Ardizzoia A, Brivio F, Barni S, et al. (1996) Prevention of cytokine-induced hypotension in cancer patients by the pineal hormone melatonin. Support Care Cancer 4: 313-316.

253. Lissoni P, Paolorossi F, Tancini G, Barni S, Ardizzoia A, et al. (1996) Is there a role for melatonin in the treatment of neoplastic cachexia? Eur $\mathrm{J}$ Cancer 32 1340-1343.

254. Lissoni P, Paolorossi F, Tancini G, Ardizzoia A, Barni S, et al. (1996) A phase II study of tamoxifen plus melatonin in metastatic solid tumour patients. $\mathrm{Br} J$ Cancer 74: 1466-1468.

255. Lissoni P, Brivio O, Brivio F, Barni S, Tancini G, et al. (1996) Adjuvant therapy with the pineal hormone melatonin in patients with lymph node relapse due to malignant melanoma. J Pineal Res 21: 239-242.

256. Lissoni P, Cazzaniga M, Tancini G, Scardino E, Musci R, et al. (1997) Reversal of clinical resistance to LHRH analogue in metastatic prostate cancer by the pineal hormone melatonin: efficacy of LHRH analogue plus melatonin in patients progressing on LHRH analogue alone. Eur Urol 31: 178-181.

257.Lissoni P, Paolorossi F, Ardizzoia A, Barni S, Chilelli M, et al. (1997) A randomized study of chemotherapy with cisplatin plus etoposide versus chemoendocrine therapy with cisplatin, etoposide and the pineal hormone melatonin as a first-line treatment of advanced non-small cell lung cancer patients in a poor clinical state. J Pineal Res 23: 15-19.

258. Lissoni P, Tancini G, Barni S, Paolorossi F, Ardizzoia A, et al. (1997) Treatment of cancer chemotherapy-induced toxicity with the pineal hormone melatonin. Support Care Cancer 5: 126-129.

259. Neri B, de LV, Gemelli MT, di LF, Mottola A, et al. (1998) Melatonin as biological response modifier in cancer patients. Anticancer Res 18: 1329-1332.

260. Lissoni P, Giani L, Zerbini S, Trabattoni P, Rovelli F (1998) Biotherapy with the pineal immunomodulating hormone melatonin versus melatonin plus aloe vera in untreatable advanced solid neoplasms. Nat Immun 16: 27-33.

261. Ghielmini M, Pagani O, de JJ, Pampallona S, Conti A, et al. (1999) Doubleblind randomized study on the myeloprotective effect of melatonin in combination with carboplatin and etoposide in advanced lung cancer. $\mathrm{Br} J$ Cancer 80: 1058-1061.

262. Lissoni P, Tancini G, Paolorossi F, Mandala M, Ardizzoia A, et al. (1999) Chemoneuroendocrine therapy of metastatic breast cancer with persistent thrombocytopenia with weekly low-dose epirubicin plus melatonin: a phase II study. J Pineal Res 26: 169-173.

263. Lissoni P, Barni S, Mandala M, Ardizzoia A, Paolorossi F, et al. (1999) Decreased toxicity and increased efficacy of cancer chemotherapy using the pineal hormone melatonin in metastatic solid tumour patients with poor clinical status. Eur J Cancer 35: 1688-1692.

264. Lissoni P, Mandala M, Brivio F (2000) Abrogation of the negative influence of opioids on IL-2 immunotherapy of renal cell cancer by melatonin. Eur Urol 38: $115-118$.

265. Lissoni P, Bucovec R, Bonfanti A, Giani L, Mandelli A, et al. (2001) Thrombopoietic properties of 5-methoxytryptamine plus melatonin versus melatonin alone in the treatment of cancer-related thrombocytopenia. J Pineal Res 30: 123-126.

266. Lissoni P, Rovelli F, Malugani F, Bucovec R, Conti A, et al. (2001) Antiangiogenic activity of melatonin in advanced cancer patients. Neuro Endocrinol Lett 22: 45-47.

267. Yan JJ, Shen F, Wang K, Wu MC (2002) Patients with advanced primary hepatocellular carcinoma treated by melatonin and transcatheter arterial chemoembolization: a prospective study. Hepatobiliary Pancreat Dis Int 1: 183-186.

268. Lissoni P, Vaghi M, Ardizzoia A, Malugani F, Fumagalli E, et al. (2002) A phase II study of chemoneuroimmunotherapy with platinum, subcutaneous low-dose interleukin-2 and the pineal neurohormone melatonin (P.I.M.) as a secondline therapy in metastatic melanoma patients progressing on dacarbazine plus interferon-alpha. In Vivo 16: 93-96.

269. Lissoni P, Malugani F, Malysheva O, Kozlov V, Laudon M, et al. (2002) Neuroimmunotherapy of untreatable metastatic solid tumors with subcutaneous low-dose interleukin-2, melatonin and naltrexone: modulation of interleukin-2-induced antitumor immunity by blocking the opioid system. Neuro Endocrinol Lett 23: 341-344.

270. Cerea G, Vaghi M, Ardizzoia A, Villa S, Bucovec R, et al. (2003) Biomodulation of cancer chemotherapy for metastatic colorectal cancer: a randomized study of weekly low-dose irinotecan alone versus irinotecan plus the oncostatic pineal hormone melatonin in metastatic colorectal cancer patients progressing on 5-fluorouracil-containing combinations. Anticancer Res 23: 1951-1954

271. Lissoni P, Chilelli M, Villa S, Cerizza L, Tancini G (2003) Five years survival in metastatic non-small cell lung cancer patients treated with chemotherapy alone or chemotherapy and melatonin: a randomized trial. J Pineal Res 35: 12-15.

272.Persson C, Glimelius B, Ronnelid J, Nygren P (2005) Impact of fish oil and melatonin on cachexia in patients with advanced gastrointestinal cancer: a randomized pilot study. Nutrition 21: 170-178. 
Citation: Cardinali D, Escames G, Acuña-Castroviejo D, Ortiz F, Fernández-Gil B, et al. (2016) Melatonin-Induced Oncostasis, Mechanisms and Clinical Relevance. J Integr Oncol S1: 006. doi:10.4172/2329-6771.S1-006

Page 25 of 25

273. Lissoni $P$ (2007) Biochemotherapy with immunomodulating pineal hormones other than melatonin: 5-methoxytryptamine as a new oncostatic pineal agent. Pathol Biol (Paris) 55: 198-200.

274. Lissoni P, Brivio F, Fumagalli L, Messina G, Vigore L, et al. (2008) Neuroimmunomodulation in medical oncology: application of psychoneuroimmunology with subcutaneous low-dose IL-2 and the pineal hormone melatonin in patients with untreatable metastatic solid tumors Anticancer Res 28: 1377-1381.

275. Lissoni P, Rovelli F, Brivio F, Fumagalli L, Brera G (2008) A study of immunoendocrine strategies with pineal indoles and interleukin-2 to prevent radiotherapy-induced lymphocytopenia in cancer patients. In Vivo 22: $397-$ 400

276. Brivio F, Fumagalli L, Fumagalli G, Pescia S, Brivio R, et al. (2010) Synchronization of cortisol circadian rhythm by the pineal hormone melatonin in untreatable metastatic solid tumor patients and its possible prognostic significance on tumor progression. In Vivo 24: 239-241.

277. Vigore L, Messina G, Brivio F, Fumagalli L, Rovelli F, et al. (2010) Psychoneuroendocrine modulation of regulatory $T$ lymphocyte system: in vivo and in vitro effects of the pineal immunomodulating hormone melatonin. In Vivo 24: 787-789.

This article was originally published in a special issue, Oncology and

Biophysics: A Need for Integration handled by Editor(s). Dr. Sarah S Knox, West Virgnia University 